\title{
GEOHYDROLOGY AND NUMERICAL SIMULATION OF THE GROUND-WATER FLOW SYSTEM OF MOLOKAI, HAWAII
}

By Delwyn S. Oki

U.S. GEOLOGICAL SURVEY

Water-Resources Investigations Report 97-4176

Prepared in cooperation with the STATE OF HAWAII DEPARTMENT OF HAWAIIAN HOME LANDS

Honolulu, Hawaii

1997

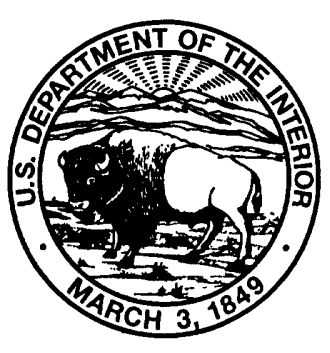




\section{U.S. DEPARTMENT OF THE INTERIOR \\ BRUCE BABBITT, Secretary}

\section{U.S. GEOLOGICAL SURVEY}

Gordon P. Eaton, Director

The use of firm, trade, and brand names in this report is for identification purposes only and does not constitute endorsement by the U.S. Geological Survey.

For additional information write to:

District Chief

U.S. Geological Survey

677 Ala Moana Blvd., Suite 415

Honolulu, HI 96813

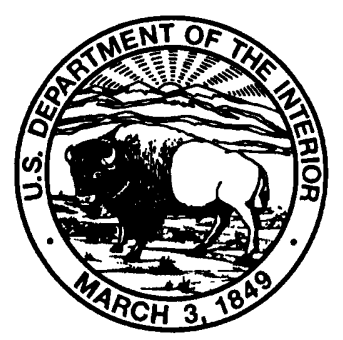




\section{CONTENTS}

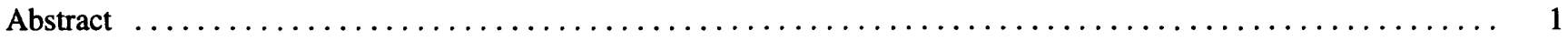

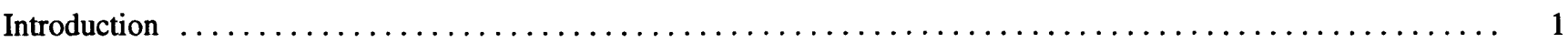

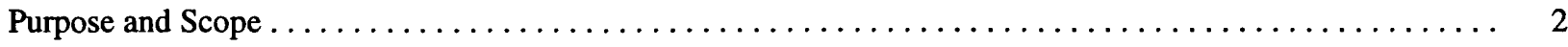

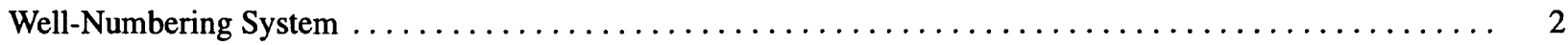

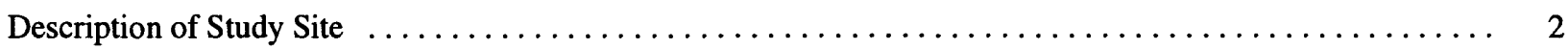

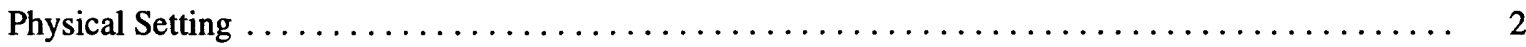

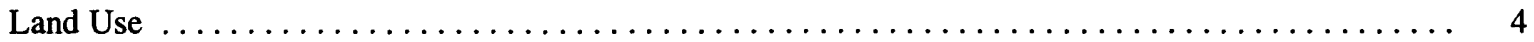

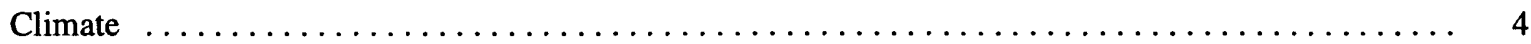

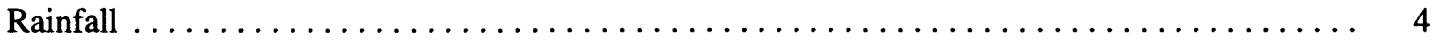

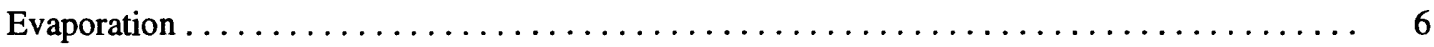

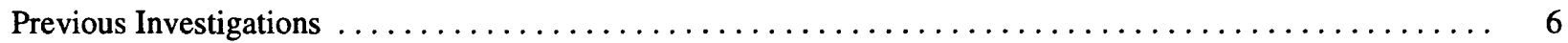

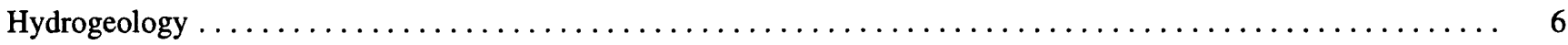

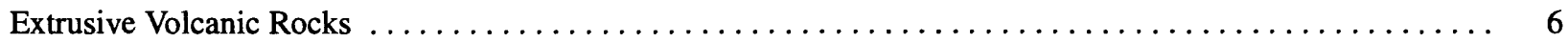

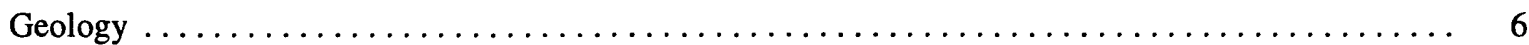

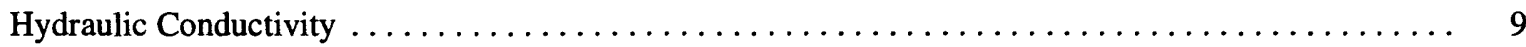

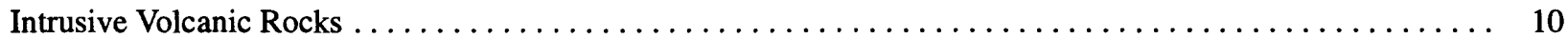

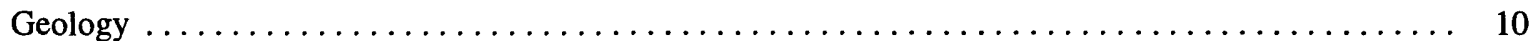

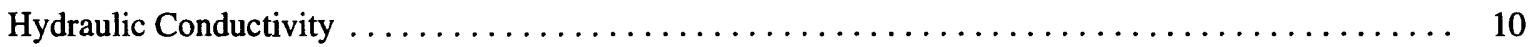

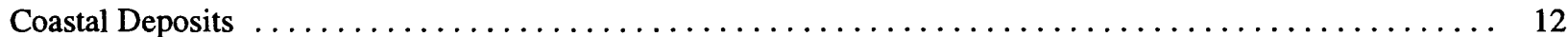

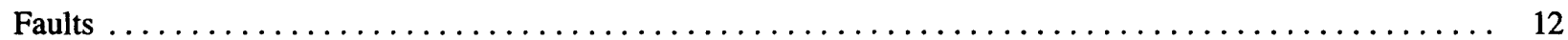

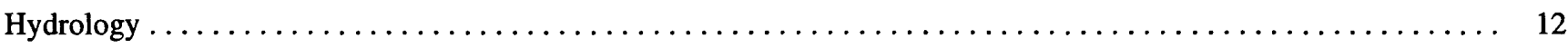

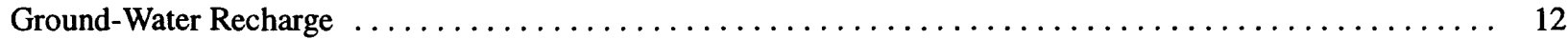

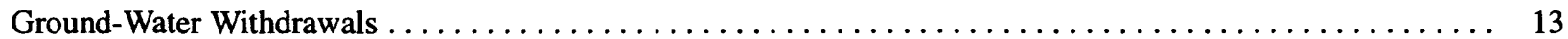

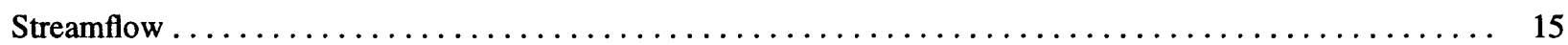

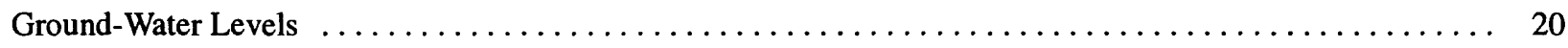

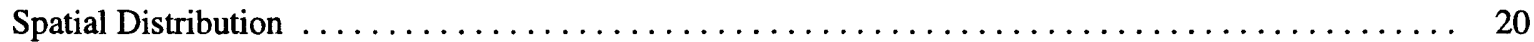

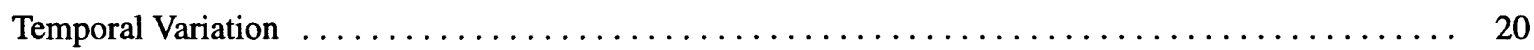

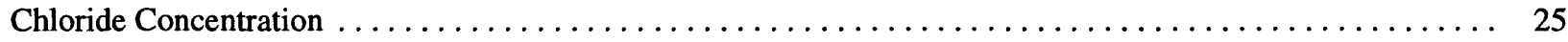

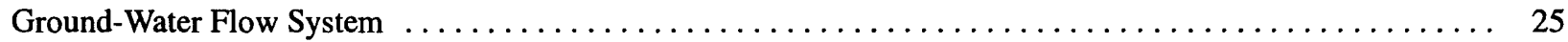

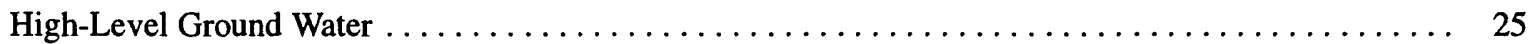

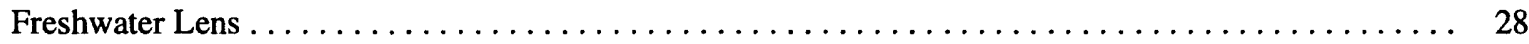

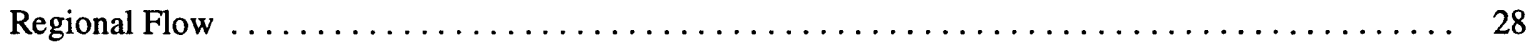

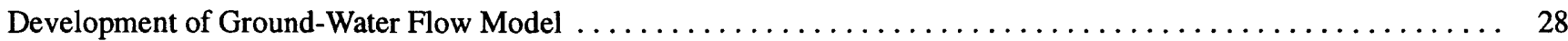

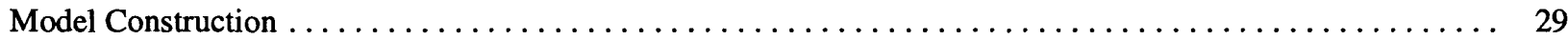

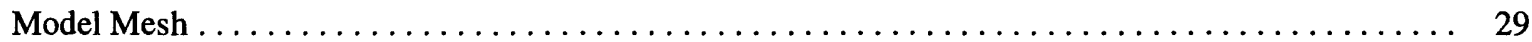

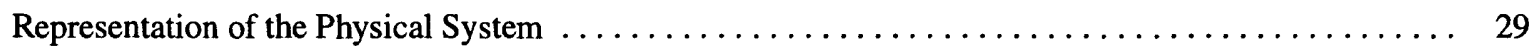

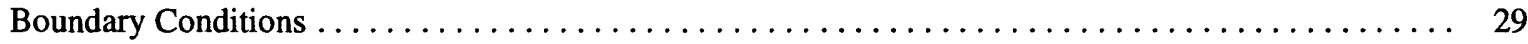

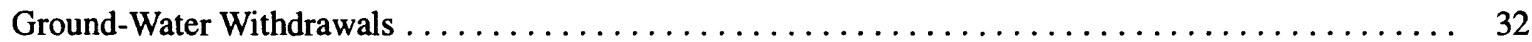

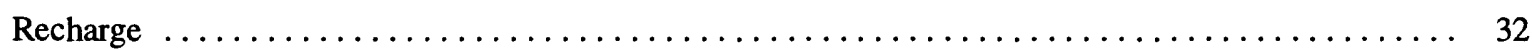

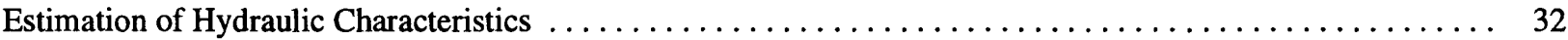

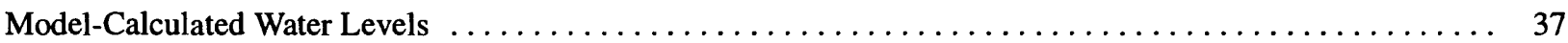

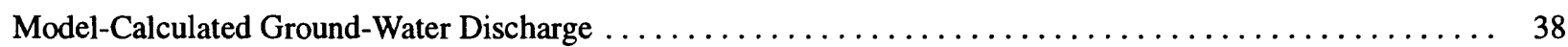

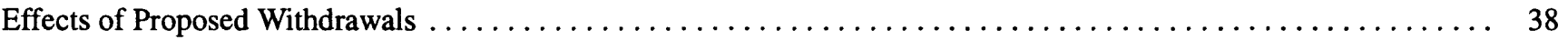




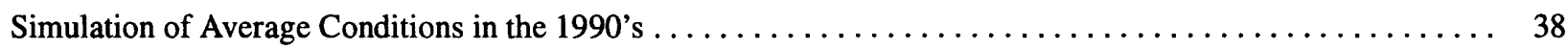

Simulation of the Hydrologic Effects of Additional Withdrawals $\ldots \ldots \ldots \ldots \ldots \ldots \ldots \ldots \ldots \ldots \ldots \ldots . \ldots 1$

Scenarios 1 and 2--Additional Withdrawal from the Kamiloloa Area $\ldots \ldots \ldots \ldots \ldots \ldots \ldots \ldots .41$

Scenario 3--Additional Withdrawal from the Kualapuu Area $\ldots \ldots \ldots \ldots \ldots \ldots \ldots \ldots \ldots \ldots .46$

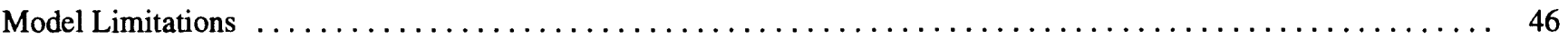

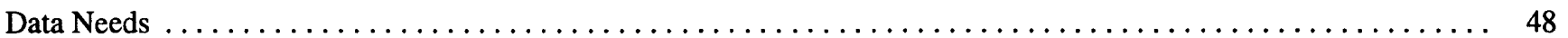

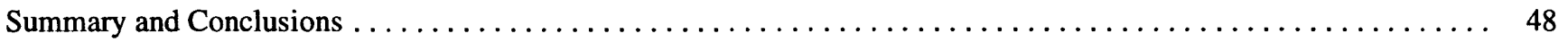

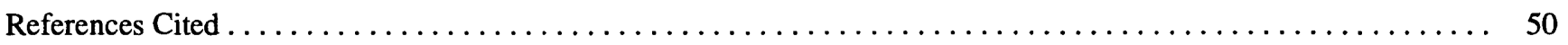

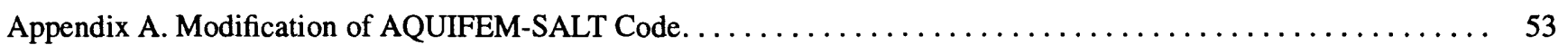

Appendix B. Model Response to Changes in Hydraulic Characteristics $\ldots \ldots \ldots \ldots \ldots \ldots \ldots \ldots \ldots \ldots \ldots \ldots .54$

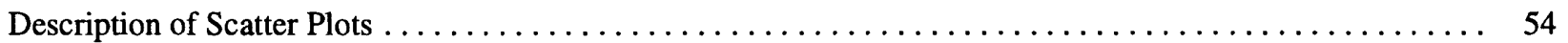

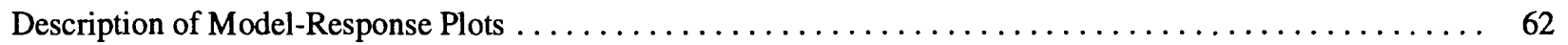

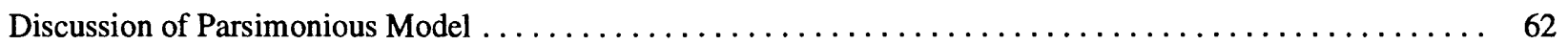

\section{FIGURES}

1-2. Maps showing:

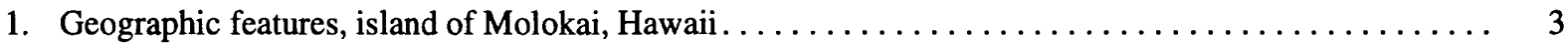

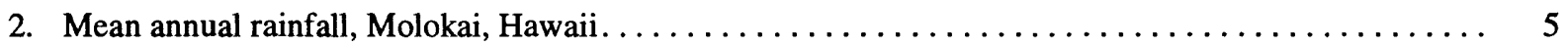

3. Chart showing annual rainfall at Kualapuu and Kaunakakai rain gages, Molokai, Hawaii........... 7

4-6. Maps showing:

4. Generalized surficial geology of Molokai, Hawaii $\ldots \ldots \ldots \ldots \ldots \ldots \ldots \ldots \ldots \ldots \ldots \ldots \ldots \ldots$

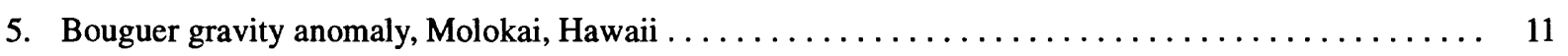

6. Estimated areas of pineapple cultivation, $1954-61$, Molokai, Hawaii $\ldots \ldots \ldots \ldots \ldots \ldots \ldots \ldots .14$

7. Chart showing monthly mean water use for pineapple irrigation in the Kualapuu area, 1954-61,

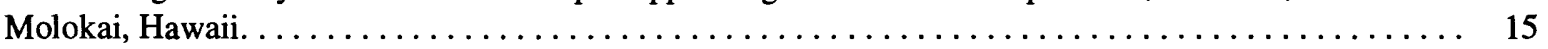

8. Map showing locations of selected wells, Molokai, Hawaii $\ldots \ldots \ldots \ldots \ldots \ldots \ldots \ldots \ldots \ldots \ldots \ldots$

9. Chart showing monthly or annual mean pumpage from selected wells, Molokai, Hawaii ......... 17

10-11. Maps showing:

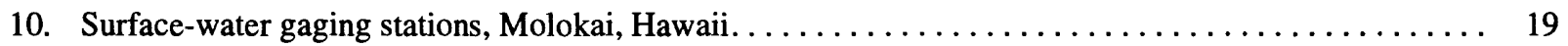

11. Average measured water levels and water-table altitude from resistivity measurements,

Molokai, Hawaii. . . . . . . . . . . . . . . . . . . . . . . . . . . . . .

12-13. Charts showing:

12. Water levels from selected wells, Molokai, Hawaii $\ldots \ldots \ldots \ldots \ldots \ldots \ldots \ldots \ldots \ldots \ldots \ldots \ldots$

13. Chloride concentrations of ground water from selected wells, Molokai, Hawaii . . . . . . . . . . . . 26

14-18. Model grids showing:

14. Horizontal hydraulic-conductivity zones used in the ground-water flow model, Molokai, Hawaii . . ... 30

15. Ground-water discharge zones used in the ground-water flow model, Molokai, Hawaii . . . . . . . . 31

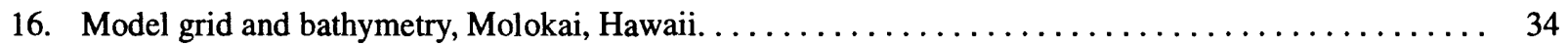

17. Model grid and estimated thickness of the southern coastal deposits, Molokai, Hawaii .......... 35

18. Average annual recharge used in the ground-water flow model and nodes with simulated ground-water withdrawal, $1954-61$, Molokai, Hawaii $\ldots \ldots \ldots \ldots \ldots \ldots \ldots \ldots \ldots \ldots \ldots$

19. Plot showing final model-calculated and measured water levels, 1954-61, Molokai, Hawaii ......... 38

20. Map showing measured and model-calculated water levels, $1954-61$, Molokai, Hawaii ............ 39 
21. Model grid showing average annual recharge used in the ground-water flow model and nodes with simulated ground-water withdrawal, $1992-96$, Molokai, Hawaii . . . . . . . . . . . . . . . . .

22-26. Maps showing:

22. Measured and model-calculated water levels, 1992-96, Molokai, Hawaii.................

23. Model-calculated ground-water flow directions for average 1992-96 pumping conditions, Molokai, Hawaii. . . . . . . . . . . . . . . . . . . . . . . . . . . .

24. Model-calculated water-level drawdown, relative to average 1992-96 conditions, caused by additional withdrawal of $0.337 \mathrm{Mgal} / \mathrm{d}$ at proposed Kamiloloa well, Molokai, Hawaii . . . . . . . . .

25. Model-calculated water-level drawdown, relative to average 1992-96 conditions, caused by additional withdrawal of $1.326 \mathrm{Mgal} / \mathrm{d}$ at proposed Kamiloloa well, Molokai, Hawaii . . . . . . . . .

26. Model-calculated water-level drawdown, relative to average 1992-96 conditions, caused by additional withdrawal of $0.826 \mathrm{Mgal} / \mathrm{d}$ at Kualapuu well (0901-01), Molokai, Hawaii ...........

\section{Appendix figures}

A1. Finite-element strip model for test of AQUIFEM-SALT code modification $\ldots \ldots \ldots \ldots \ldots \ldots \ldots \ldots$

B1-B4. Plots showing:

B1. Model-calculated and measured water levels for the period 1954-61, Molokai, Hawaii, for various values of the vertical hydraulic conductivity of the southern coastal-discharge zone, a leakance of 0.001 per day for the northern coastal-discharge zone, and an isotropic horizontal hydraulic conductivity of $\mathbf{5 0 0}$ feet per day for the model zones representing the dike-free West and East Molokai Volcanics and East Molokai marginal dike zone...................

B2. Model-calculated and measured water levels for the period 1954-61, Molokai, Hawaii, for various values of the vertical hydraulic conductivity of the southern coastal-discharge zone, a leakance of 0.1 per day for the northern coastal-discharge zone, and an isotropic horizontal hydraulic conductivity of $\mathbf{5 0 0}$ feet per day for the model zones representing the dike-free West and East Molokai Volcanics and East Molokai marginal dike zone...................

B3. Model-calculated and measured water levels for the period 1954-61, Molokai, Hawaii, for various values of the vertical hydraulic conductivity of the southern coastal-discharge zone, a leakance of 0.001 per day for the northern coastal-discharge zone, and an isotropic horizontal hydraulic conductivity of 1,000 feet per day for the model zones representing the dike-free West and East Molokai Volcanics and East Molokai marginal dike zone . . . . . . . . . . . . . . . .

B4. Model-calculated and measured water levels for the period 1954-61, Molokai, Hawaii, for various values of the vertical hydraulic conductivity of the southern coastal-discharge zone, a leakance of 0.1 per day for the northern coastal-discharge zone, and an isotropic horizontal hydraulic conductivity of 1,000 feet per day for the model zones representing the dike-free West and East Molokai Volcanics and East Molokai marginal dike zone. . . . . . . . . . . . . . . .

B5-B6. Charts showing:

B5. Response of the ground-water flow model to the vertical hydraulic conductivity of the southern coastal-discharge zone for a leakance of 0.001 per day for the northern coastal-discharge zone, and isotropic horizontal conductivities of 250;500;1,000; and 2,000 feet per day for the model zones representing the dike-free West and East Molokai Volcanics and East Molokai marginal dike zone. . . . . . . . . . . . . . . . . . . . . . . . . . . . . . . . . . . .

B6. Response of the ground-water flow model to the vertical hydraulic conductivity of the southern coastal-discharge zone for a leakance of 0.1 per day for the northern coastal-discharge zone, and isotropic horizontal conductivities of 250;500;1,000; and 2,000 feet per day for the model zones representing the dike-free West and East Molokai Volcanics and East Molokai marginal dike zone. 


\section{TABLES}

1. Estimated baseflow for northeastern Molokai streams, Hawaii $\ldots \ldots \ldots \ldots \ldots \ldots \ldots \ldots \ldots \ldots \ldots \ldots .20$

2. Summary of measured water levels at selected wells, Molokai, Hawaii $\ldots \ldots \ldots \ldots \ldots \ldots \ldots \ldots \ldots \ldots \ldots$

3. Pumping rates used in the ground-water flow model, Molokai, Hawaii $\ldots \ldots \ldots \ldots \ldots \ldots \ldots \ldots \ldots \ldots \ldots$

4. Final parameter values used in the Molokai ground-water flow model, Hawaii $\ldots \ldots \ldots \ldots \ldots \ldots \ldots \ldots .33$

5. Recharge used in the model and distribution of model-calculated ground-water discharge,

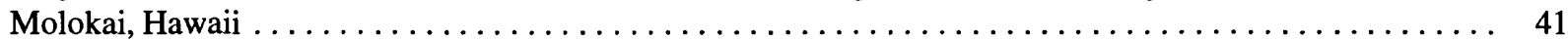




\section{Geohydrology and Numerical Simulation of the Ground- Water Flow System of Molokai, Hawaii}

\author{
By Delwyn S. Oki
}

\section{Abstract}

A two-dimensional, steady-state, areal ground-water flow model was developed for the island of Molokai, Hawaii, to enhance the understanding of (1) the conceptual framework of the ground-water flow system, (2) the distribution of aquifer hydraulic properties, and (3) the regional effects of ground-water withdrawals on water levels and coastal discharge. The model uses the finite-element code AQUIFEM-SALT, which simulates flow of fresh ground water in systems that may have a freshwater lens floating on denser underlying saltwater.

Model results are in agreement with the general conceptual model of the flow system on Molokai, where ground water flows from the interior, high-recharge areas to the coast. The model-calculated ground-water divide separating flow to the northern and southern coasts lies to either the north or the south of the topographic divide but is generally not coincident with the topographic divide.

On the basis of model results, the following horizontal hydraulic conductivities were estimated: (1) 1,000 feet per day for the dike-free volcanic rocks of East and West Molokai, (2) 100 feet per day for the marginal dike zone of the East Molokai Volcano, (3) 2 feet per day for the West Molokai dike complex, (4) 0.02 feet per day for the East Molokai dike complex, and (5) 500 feet per day for the Kalaupapa Volcanics.

Three simulations to determine the effects of proposed ground-water withdrawals on water levels and coastal discharge, relative to model-calculated water levels and coastal discharge for 1992-
96 withdrawal rates, show that the effects are widespread. For a withdrawal rate of 0.337 million gallons per day from a proposed well about 4 miles southeast of Kualapuu and 3 miles north of Kamiloloa, the model-calculated drawdown of 0.01 foot or more extends 4 miles southeast and 6 miles northwest from the well. For a withdrawal rate of 1.326 million gallons per day from the same well, the model-calculated drawdown of 0.01 foot or more extends 6 miles southeast and 9 miles northwest from the well. In a third scenario, the withdrawal rate from an existing well near Kualapuu was increased by 0.826 million gallons per day. The model-calculated drawdown of 0.01 foot or more extends 6 miles southeast and 8 miles northwest from the well. In all scenarios, coastal discharge is reduced by an amount equal to the additional withdrawal.

Additional data needed to improve the understanding of the ground-water flow system on Molokai include: (1) a wider spatial distribution and longer temporal distribution of water-levels, (2) independent estimates of hydraulic conductivity, (3) improved recharge estimates, (4) information about the vertical distribution of salinity in ground water, (5) streamflow data at additional sites, and (6) improved information about the subsurface geology.

\section{INTRODUCTION}

In response to projected water demand on the island of Molokai, the State of Hawaii Commission on Water Resource Management (CWRM) designated the entire island as a Ground Water Management Area in 1992. This action authorized the State to manage 
ground-water withdrawals on Molokai through a permitting process to protect the water resources of the island.

The reported annual mean pumpage for Molokai during 1996 was $4.336 \mathrm{Mgal} / \mathrm{d}$ (million gallons per day) (computed from data supplied by Neal Fujii, CWRM, written commun., 1997); as of June 1997, the permitted ground-water withdrawals on Molokai totaled 8.844 Mgal/d (Neal Fujii, CWRM, written commun., 1997). Ground-water withdrawals on Molokai are currently limited by sustainable yield estimates for 16 areas denoted as aquifer systems, mainly delineated on the basis of topographic divides by Mink and Lau (1992). The total estimated sustainable yield for Molokai is $\mathbf{8 3}$ $\mathrm{Mgal} / \mathrm{d}$ (State of Hawaii, 1990), which is considerably greater than the permitted uses of $8.844 \mathrm{Mgal} / \mathrm{d}$. The sustainable yield estimates, however, were made on the basis of an analytical model that does not consider ground-water flow across aquifer system boundaries or the regional effects of withdrawals on ground-water levels, streamflow, and coastal springs. Current knowledge of the hydrologic effects of ground-water withdrawals on Molokai is limited. Given that withdrawals from one aquifer system can affect water levels, water quality, coastal discharge, and surface water-ground water interactions in other aquifer systems, a better understanding of the ground-water flow system of Molokai is needed for water-resource management purposes.

In cooperation with the State of Hawaii Department of Hawaiian Home Lands (DHHL), the U.S. Geological Survey (USGS) undertook an investigation of the ground-water flow system of Molokai. A numerical ground-water flow model of the entire island of Molokai was developed to enhance the understanding of (1) the conceptual framework of the ground-water flow system, (2) the distribution of aquifer hydraulic properties, and (3) the regional effects of ground-water withdrawals on water levels and coastal discharge. During the course of this investigation, data needs for improving the understanding of the ground-water flow system were identified.

\section{Purpose and Scope}

The purpose of this report is to describe (1) the geologic and hydrologic setting of Molokai, (2) the numerical ground-water flow model developed, (3) the results of model simulations that qualitatively assess the hydrologic effects of withdrawals at rates in excess of the average 1992-96 rates, and (4) data needs.

No new data were collected as part of this study; only existing water-level, ground-water withdrawal, and streamflow information were used to develop the conceptual framework of the ground-water flow system. A numerical ground-water flow model was used to refine the conceptual framework and to estimate the effects of different withdrawal scenarios on regional ground-water levels and ground-water discharge. The numerical model used data from the period 1954-61 to estimate hydraulic properties of the volcanic rocks and coastal deposits. Average ground-water withdrawals for 1992-96 and estimated long-term average natural recharge were used in the model to simulate groundwater levels and discharge, which in turn were used as the base to compute simulated drawdown and change in discharge for three withdrawal scenarios.

\section{Well-Numbering System}

Wells mentioned in this report are numbered according to the State of Hawaii numbering system. Well numbers contain seven digits and are based on a latitude-longitude one-minute grid system. Well numbers are of the form:

$$
\text { a-bbcc-dd, }
$$

where:

$a$ is the island code;

$\mathrm{bb}$ is the minutes of latitude of the southeastern corner of the one-minute grid;

$\mathrm{cc}$ is the minutes of longitude of the southeastern corner of the one-minute grid; and

$\mathrm{dd}$ is the sequential well number within the oneminute grid.

An island code of " 4 " is used for all wells on Molokai and is omitted in this report.

\section{Description of Study Site}

\section{Physical Setting}

The island of Molokai, which has an area of 261 $\mathrm{mi}^{2}$, is the fifth largest of the Hawaiian islands and is located between longitude $157^{\circ} 20^{\prime} \mathrm{W}$ and $156^{\circ} 40^{\prime} \mathrm{W}$ and between latitude $21^{\circ} 00^{\prime} \mathrm{N}$ and $21^{\circ} 15^{\prime} \mathrm{N}$ (fig. 1). It 

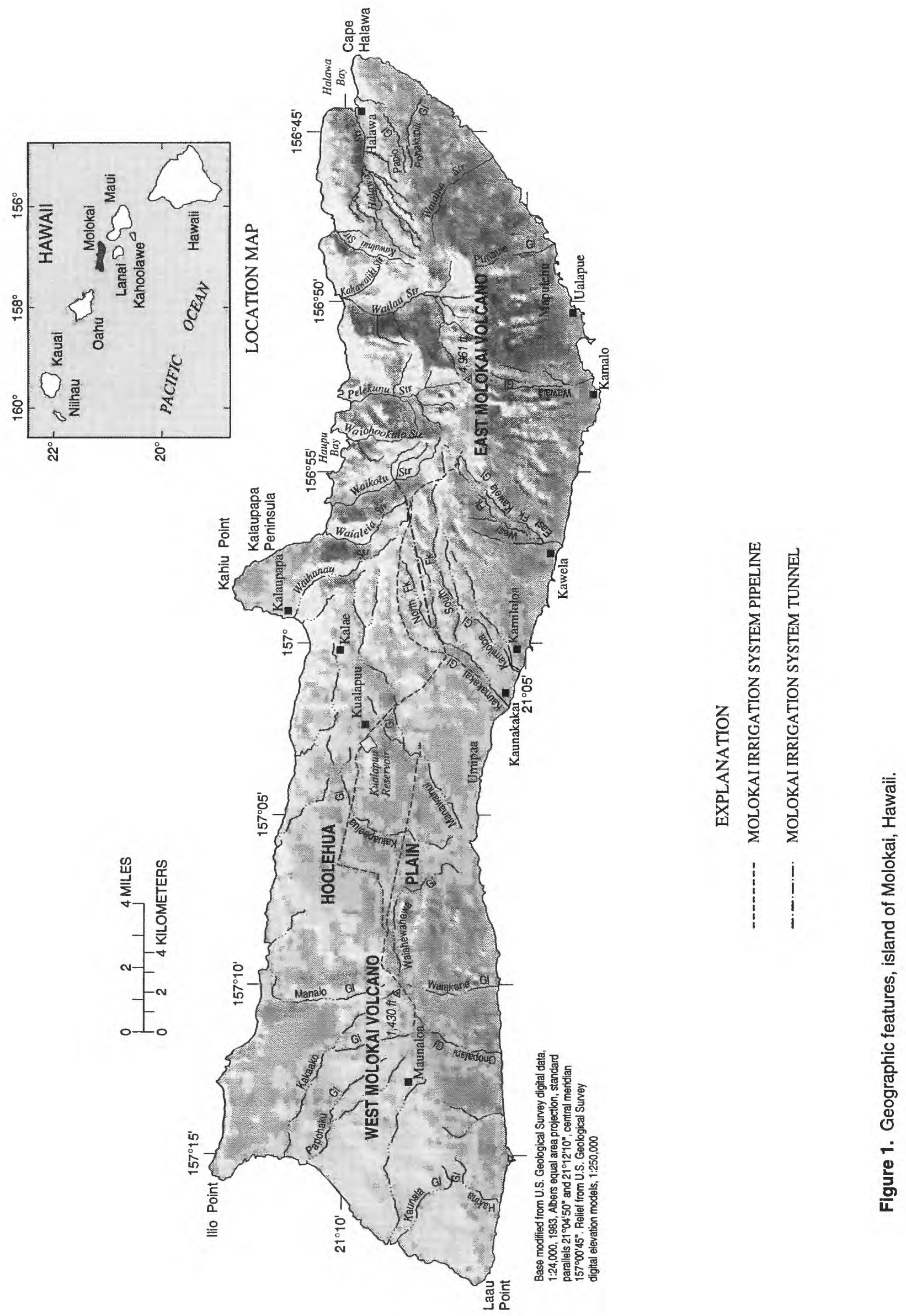
is composed mainly of two coalesced shield volcanoes (Stearns and Macdonald, 1947): the older West Molokai Volcano, which rises to an altitude of $1,430 \mathrm{ft}$, and the younger East Molokai Volcano, which rises to an altitude of 4,961 ft. The Hoolehua Plain lies in the central saddle area of the island at altitudes less than about $800 \mathrm{ft}$. A high sea cliff runs along much of the northern coast. Kalaupapa Peninsula, formed by a rejuvenatedstage volcanic vent associated with the East Molokai Volcano, extends beyond the northern sea cliff. A coastal plain lies along the southern coast.

\section{Land Use}

Land use on Molokai is classified by the Hawaii State Land Use Commission into conservation, urban, rural, and agricultural areas. The conservation areas cover $77.8 \mathrm{mi}^{2}$ (Oliver, 1995) mainly in the wet, northeastern part of the island. Urban and rural areas cover $6.8 \mathrm{mi}^{2}$ (Oliver, 1995) mainly near the towns of Maunaloa, Kualapuu, Kalae, and Kalaupapa and along the southern, eastern, and western coasts. The remainder of the island is classified as agricultural land used for, among other things, field crops, nurseries, and livestock grazing.

A large-scale sugarcane operation was unsuccessfully attempted in 1898 by the American Sugar Company. Sugarcane was planted on about $0.8 \mathrm{mi}^{2}$ on the Hoolehua Plain and irrigated with pumped ground water. The operation failed because of a lack of a reliable freshwater source (Stearns and Macdonald, 1947, p. 5).

In 1923, Libby, McNeill, \& Libby began largescale pineapple operations near the plantation town of Maunaloa, and in 1927, the California Packing Corporation began large-scale pineapple operations near Kualapuu (Anderson and others, 1973). By 1945, pineapple was grown on $13.2 \mathrm{mi}^{2}$ by Libby, McNeill, \& Libby and on $7.5 \mathrm{mi}^{2}$ by California Packing Corporation (Stearns and Macdonald, 1947, p. 5). In 1968, pineapple was grown on $27.0 \mathrm{mi}^{2}$ of Molokai (State of Hawaii, 1975). At the end of 1975, Dole Company, which had taken over the pineapple operations of Libby, McNeill, \& Libby, ceased operations (The Honolulu Advertiser, August 9, 1975, p. A1). Del Monte Corporation (formerly California Packing Corporation) closed its operations at the end of 1988 (The Honolulu Advertiser, May 8, 1987, p. A1).
Molokai Ranch, which is currently owned by Brierley Investments Limited of New Zealand, controls about a third of the land on Molokai. Their land is used mainly for grazing and recreation. In western Molokai, Kukui (Molokai), Inc., which is owned by Tokyo Kosan, controls about $7.5 \mathrm{mi}^{2}$ of land. Alpha USA, a subsidiary of Seikihyo Seibaku Co., Ltd. of Japan, controls about $9.5 \mathrm{mi}^{2}$ of land in southwestern Molokai (The Honolulu Advertiser, December 5, 1994, p. A2). In central and eastern Molokai, the land is controlled mainly by the State of Hawaii and private land owners. DHHL controls $39.7 \mathrm{mi}^{2}$, or about 15 percent of land on Molokai (The Honolulu Advertiser, June 22, 1997. p. A1).

\section{Climate}

The climate of Molokai is characterized by mild temperatures, cool and persistent tradewinds, a rainy winter season from October through April, and a dry summer season from May through September (Blumenstock and Price, 1967). Climate is controlled primarily by topography and the location of the north Pacific anticyclone and other migratory systems relative to the island. During the dry season the stability of the north Pacific anticyclone produces persistent northeasterly winds known locally as tradewinds. Summer tradewinds blow 80 to 95 percent of the time. During the rainy season migratory high-pressure systems often move past the Hawaiian islands resulting in less persistent tradewinds. Winter tradewinds blow 50 to 80 percent of the time. Southerly winds associated with lowpressure systems can bring heavy rains to the island. The dry coastal areas receive much of their rainfall as a result of these low-pressure systems.

\section{Rainfall}

Rainfall on Molokai is characterized by maxima at high altitudes and steep spatial gradients (fig. 2). Highest mean annual rainfall occurs in northeastern Molokai. The maximum mean annual rainfall is near the summit of the East Molokai Volcano and exceeds 150 in. Over West Molokai Volcano, the maximum mean annual rainfall is about $25 \mathrm{in}$. Along the coastal areas of southern and western Molokai, mean annual rainfall is less than 16 in. For comparison, mean annual rainfall over the open ocean is estimated to be between 21.7 in. and 27.6 in. (Elliot and Reed, 1984; Dorman and Bourke, 1979). 


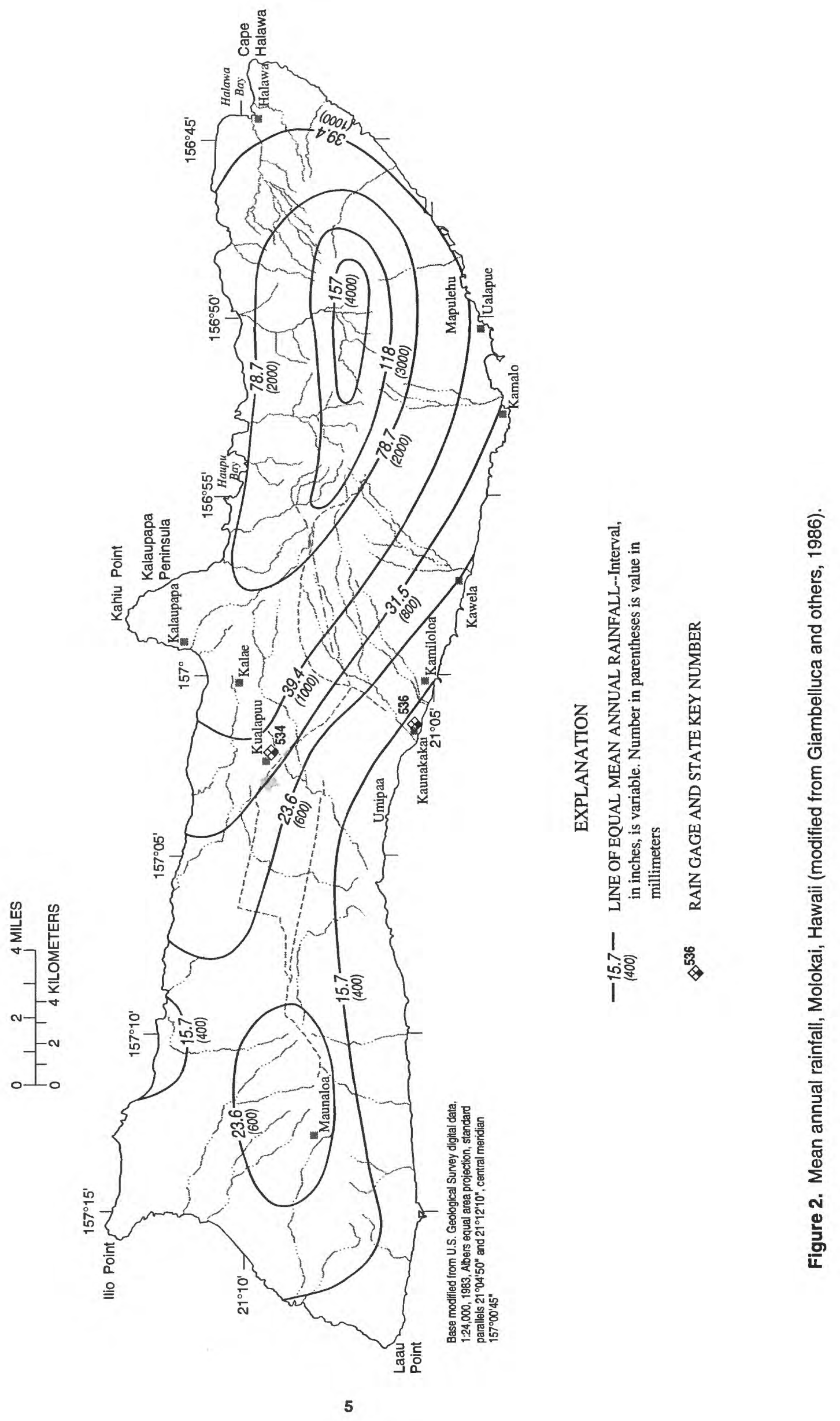


The spatial distribution of rainfall on East Molokai Volcano is influenced by topography. Warm, moistureladen air flowing over the ocean from the northeast is forced up the slopes of the East Molokai Volcano. The warm air is orographically lifted, cooled, and condensed resulting in cloud formation and precipitation. Giambelluca and others (1986) note that the rainfall maximum over East Molokai Volcano is not as great as for other peaks of similar altitude in Hawaii because the mountain's ridge line is oriented roughly parallel to the northeasterly tradewinds. The summit of West Molokai Volcano is much lower than the summit of East Molokai Volcano and, as a result, western Molokai is considerably drier than eastern Molokai.

Annual rainfall at Kualapuu (rain gage 534, fig. 2) varied from about 13 to 59 in. during 1900-93 (fig. 3). Farther south at Kaunakakai (rain gage 536, fig. 2) rainfall is less and has varied from about 3 to 35 in. during 1933-94 (fig. 3).

\section{Evaporation}

Published pan-evaporation records for Molokai are available for only two sites, both located in the Hoolehua Plain. Mean annual pan evaporation at the two sites ranges from 106.4 to 118.1 in. (Ekern and Chang, 1985). The high pan-evaporation rate on the dry, windy uplands of central Molokai is attributed to the extreme positive advection of heat from the dry surrounding areas (Ekern and Chang, 1985). Over the open ocean, the computed evaporation rate is about $65 \mathrm{in} / \mathrm{yr}$ (Seckel, 1962).

\section{Previous Investigations}

Lindgren (1903) made the first detailed field study of the geology and water resources of the island of Molokai. Lindgren (1903, p. 59) speculated that about $24.5 \mathrm{Mgal} / \mathrm{d}$ of ground water could be developed from wells along the southern coast of the island. Stearns and Macdonald (1947) provided a comprehensive and refined description of the geohydrologic framework of Molokai and compiled available ground-water and surface-water data. An inventory of the water resources of Molokai and sustainable yield estimates for the island are presented in a water-supply plan for CWRM (State of Hawaii, 1990). Anthony (1995) evaluated available ground-water data on Molokai by examining (1) wellconstruction and aquifer-test information, (2) historic distribution and rates of ground-water withdrawals, and
(3) spatial and temporal changes of ground-water levels and chloride concentrations.

During the latter part of 1938 , an electrical resistivity survey was completed to estimate the freshwaterlens thickness and water-table altitude in western and central Molokai (Swartz, 1939). From the results of the resistivity survey, MacCarthy (1941) estimated that the water table was about 1 to $14 \mathrm{ft}$ above sea level within the surveyed area. Other geophysical studies on Molokai include gravity (Moore and Krivoy, 1965; Strange and others, 1965) and magnetic (Malahoff and Woollard, 1966) surveys which can be used to interpret the subsurface geology.

Numerous investigators (Lindgren, 1903; Howell, 1938; Stearns and Macdonald, 1947; Austin and Stearns, 1954) suggested that water from the large northeastern Molokai streams could be diverted to other areas, including the dry Hoolehua Plain. In 1962, the Molokai Irrigation System tunnel (fig. 1) was completed for the State to transport water from Waikolu Stream to the North Fork of Kaunakakai Gulch (Hirashima, 1963). A pipeline (fig. 1), also part of the Molokai Irrigation System, transports the diverted surface water and ground water to the central and western parts of the island.

\section{HYDROGEOLOGY}

The island of Molokai is formed primarily by the extrusive shield- and postshield-stage lavas of the older West Molokai Volcano and the younger East Molokai Volcano, and secondarily by rejuvenated-stage volcanic rocks at Kalaupapa Peninsula (fig. 4) (Langenheim and Clague, 1987). The central saddle area between the two volcanoes was formed by lava flows from East Molokai Volcano banking up against and being deflected by the West Molokai Volcano. Intrusive volcanic rocks in the form of dikes associated with rift zones and volcanic vents exist on both West and East Molokai. Coastal deposits consisting of sediments and limestone reefs are found along the southern coast.

\section{Extrusive Volcanic Rocks}

\section{Geology}

Extrusive volcanic rocks consist mainly of lava flows that effused from fissures and vents. Lava flows 

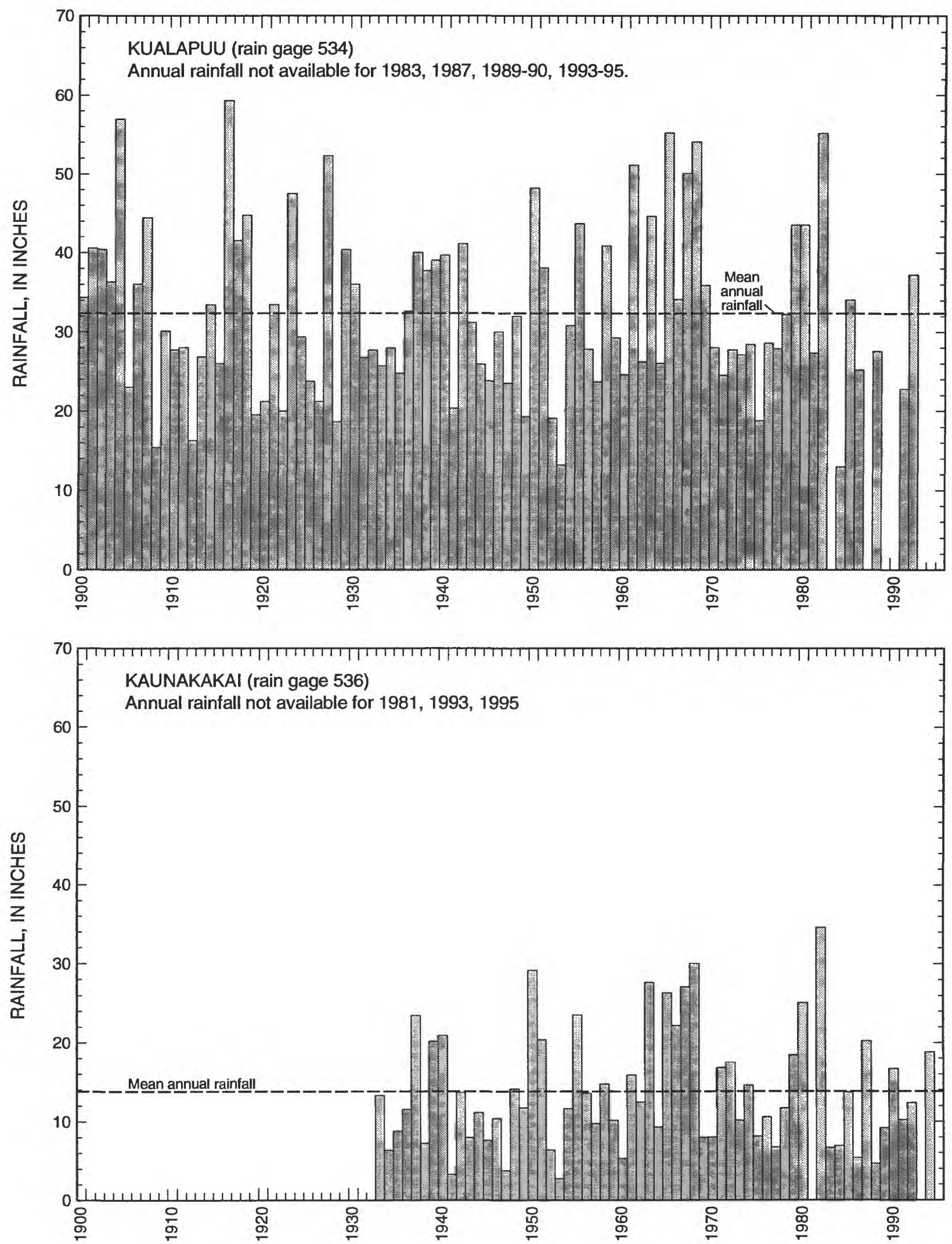

Figure 3. Annual rainfall at Kualapuu and Kaunakakai rain gages, Molokai, Hawaii (Data from U.S. Department of Commerce, National Climatic Data Center, and State of Hawaii, Commission on Water Resources Management). 


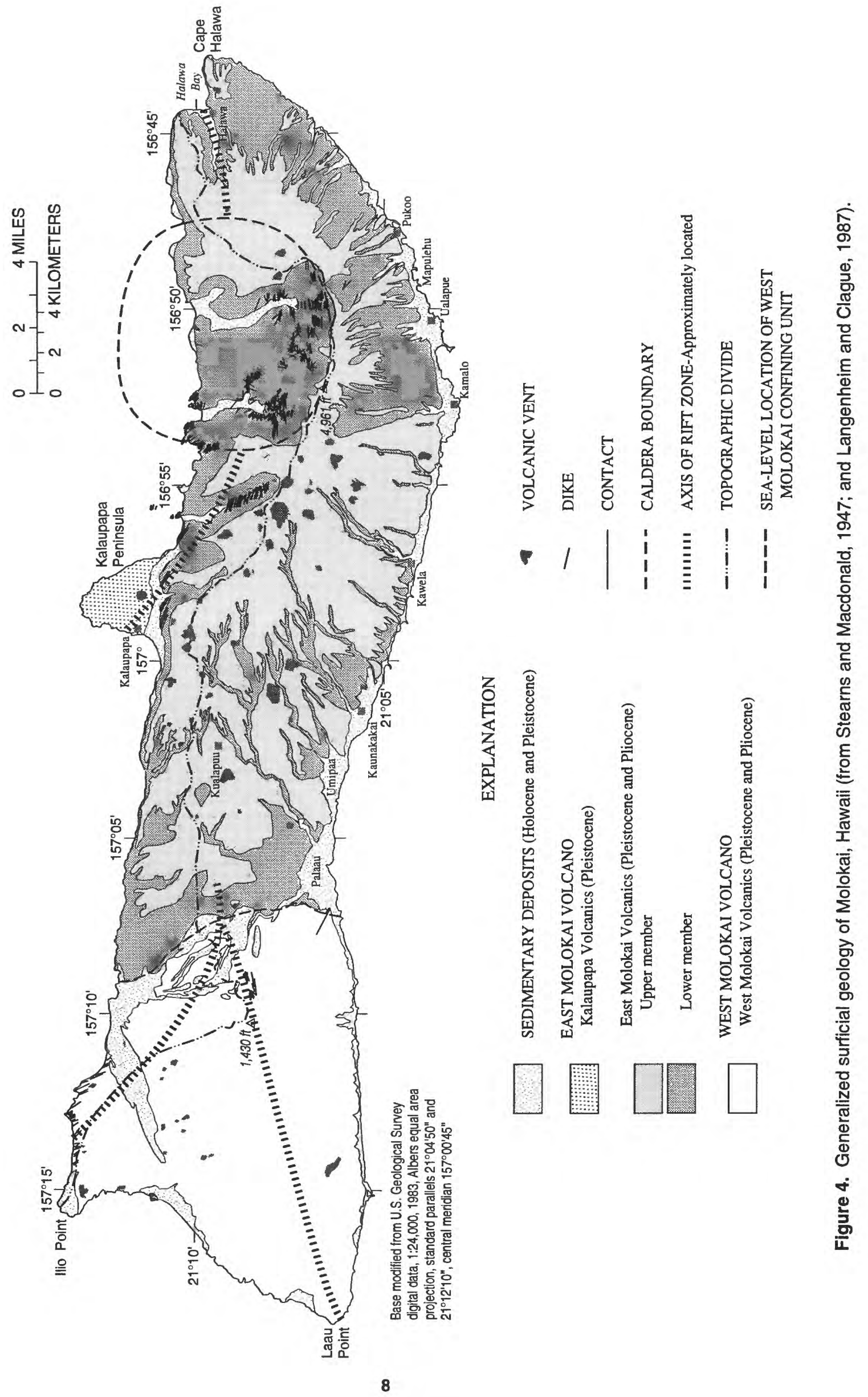


associated with the flanks and rift zones of the West and East Molokai Volcanoes form the bulk of the island.

Extrusive volcanic rocks also include pyroclastic material, such as ash, cinder, and tuff, which probably form less than 1 percent of the mass of a Hawaiian volcano (Wentworth and Macdonald, 1953).

Most lava flows emerge from fissures as pahoehoe, characterized by smooth, ropy surfaces, and can change to aa as they advance downslope. Pahoehoe flows dominate near the rift zones of volcanoes, whereas aa flows dominate farther down the flanks. Aa flows contain massive central cores typically sandwiched between rubbly clinker layers.

West Molokai is made up of shield-stage tholeiitic basalt and postshield-stage hawaiite and alkalic basalt. Collectively, the volcanic rocks of West Molokai Volcano are known as the West Molokai Volcanics (Langenheim and Clague, 1987). Potassium-argon determinations of West Molokai Volcanics indicate an age of 1.52 to $1.90 \mathrm{Ma}$ (million years) (Naughton and others, 1980; McDougall, 1964). The lavas of the West Molokai Volcano have typical dips of $2^{\circ}$ to $10^{\circ}$, except in the northeast part of the volcano where faulting has occurred.

East Molokai is made up of the East Molokai Volcanics and Kalaupapa Volcanics. The East Molokai Volcanics are divided into two informal members. The lower member consists of shield-stage tholeiitic basalt, olivine tholeiitic basalt, and picritic tholeiitic basalt, and postshield-stage alkalic basalt. The upper member consists of postshield-stage mugearite, with lesser amounts of hawaiite and trachyte. The upper member of the East Molokai Volcanics forms a relatively thin veneer, about 50 to $500 \mathrm{ft}$ thick, over the lower member (Stearns and Macdonald, 1947). Potassium-argon determinations of East Molokai Volcanics indicate an age of 1.52 to 1.76 Ma for the lower member and 1.35 to $1.49 \mathrm{Ma}$ for the upper member (Langenheim and Clague, 1987). Lavas of the East Molokai Volcano have dips of $3^{\circ}$ to $15^{\circ}$, except on the north coast between Waikolu and Wailau Streams, where dips are $8^{\circ}$ to $25^{\circ}$ southward (Stearns and Macdonald, 1947), and within the central saddle of the Hoolehua Plain, where dips are from $1^{\circ}$ to $3^{\circ}$ (Stearns and Macdonald, 1947, p. 13).

On the basis of the potassium-argon age dates, the West and East Molokai Volcanoes appear to have been formed penecontemporaneously. Stearns and Macdonald (1947) note, however, that an erosional unconformity, which dips about $10^{\circ}$ to the east, is exposed at an altitude of $250 \mathrm{ft}$ in the east bank of Waiahewahewa Gulch (fig. 1). At this site, East and West Molokai Volcanics are separated by $3 \mathrm{ft}$ of soil and $6 \mathrm{ft}$ of spheroidally weathered basalt, with the West Molokai Volcanics at the bottom of the sequence. The sequence indicates that West Molokai Volcanics are older than East Molokai Volcanics at the site of the exposed unconformity.

Kalaupapa Volcanics include the rejuvenatedstage alkalic basalt and basanite that forms Kalaupapa Peninsula (Langenheim and Clague, 1987). Age of the Kalaupapa Volcanics is estimated to be between 0.35 and 0.57 Ma (Clague and others, 1982).

\section{Hydraulic Conductivity}

Hydraulic conductivity or permeability is a measure of the capacity of a rock to transmit water. No published estimates exist for the hydraulic conductivity of dike-free extrusive volcanic rocks on Molokai. However, the permeability of the subaerial, shield-building lavas that occur along the flanks of the volcanoes generally is high (Stearns and Macdonald, 1947). The main elements of lava flows contributing to the high permeability are (1) clinker zones associated with aa flows, (2) voids along the contacts between flows, (3) cooling joints normal to flow surfaces, and (4) lava tubes associated with pahoehoe flows.

Weathering tends to reduce the permeability of the volcanic rocks. The reduction of permeability may be attributed to secondary mineralization which clogs the original open spaces, or clays and colloids that precipitate from percolating water (Mink and Lau, 1980). An injection test conducted in weathered basalt on Oahu yielded a hydraulic conductivity of $0.058 \mathrm{ft} / \mathrm{d}$ (feet per day) (R.M. Towill Corporation, 1978). On the basis of laboratory permeameter tests on core samples, Wentworth (1938) estimated the hydraulic conductivity of weathered basalt to be between 0.083 and $0.128 \mathrm{ft} / \mathrm{d}$. Miller (1987) used the water-retention characteristics of core samples collected in central Oahu to estimate the saturated hydraulic conductivity of saprolite and found values ranging from 0.0028 to $283 \mathrm{ft} / \mathrm{d}$. The wide range of hydraulic-conductivity values estimated by Miller (1987) was attributed to the variability in macroporosity among samples.

The zone of weathered West Molokai Volcanics and soil located beneath the contact of the West and East Molokai Volcanics likely impedes ground-water flow between East and West Molokai. In this report the 
zone is referred to as the West Molokai confining unit. No data are available to determine whether this unit is truly an effective barrier to ground-water flow. However, on the basis of information from Oahu on weathered volcanic rocks and a similar geohydrologic barrier (Oki, 1997), the hydraulic conductivity of the West Molokai confining unit is probably of the order of $1 \mathrm{ft} / \mathrm{d}$.

\section{Intrusive Volcanic Rocks}

\section{Geology}

Intrusive volcanic rocks include those rocks, such as dikes, that formed when magma cooled below the ground surface. Dikes associated with the rift zones of the West and East Molokai Volcanoes are the dominant intrusive rocks on Molokai, and are most abundant within the central area of the rift zones. The locations and strikes of dikes on Molokai were mapped by Stearns and Macdonald (1947) (fig. 4).

The West and East Molokai Volcanoes each have two primary rift zones (fig. 4) (Stearns and Macdonald, 1947; Moore and Krivoy, 1965; Langenheim and Clague, 1987). These rift zones are marked by cinder and spatter cones and by subvertical and nearly parallel dikes. The dikes and the rocks they intrude are collectively referred to as dike complexes. Within the central part of a dike complex, the dike rocks typically compose 10 percent or more of the total rock volume. At the outer part of the dike complex, within the marginal dike zone, dikes usually constitute less than 5 percent of the total rock volume (Takasaki and Mink, 1985). Wentworth and Macdonald (1953) estimated that 200 dikes are needed to build $1,000 \mathrm{ft}$ of a shield volcano. The rift zones are hydrologically important because dikes have low permeability and tend to impound ground-water to high altitudes within inter-dike compartments.

The primary rift zones of the West Molokai Volcano trend roughly northwest and southwest (fig. 4) in the direction of broad ridges that extend from near the summit of the volcano. The northwest rift zone is marked by numerous dikes exposed by erosion along the northern coast. The southwest rift zone is marked by several southwest-trending dikes near the summit region. In addition, a positive gravity anomaly that extends from near the summit region through Laau Point at the southwestern tip of the island (Moore and Krivoy, 1965; Strange and others, 1965) (fig. 5) suggests the presence of dense, intrusive dikes associated with the southwest rift zone. A few southeast-trending dikes exposed near the southern coast may be evidence of a third rift zone associated with West Molokai Volcano. There is no surface evidence of a summit caldera on West Molokai Volcano (Langenheim and Clague, 1987).

The primary rift zones of the East Molokai Volcano trend northwest and east, emanating from a central caldera complex (fig. 4). Macdonald (1956) suggests that there also may be a southern rift zone emanating from the caldera. Furthermore, on the basis of a magnetic survey, Malahoff and Woollard (1966) suggest that there may be a southwest rift zone emanating from the caldera complex. The northwest and east rift zones are marked by numerous vertical to nearly vertical intrusive dikes (Stearns and Macdonald, 1947). The caldera complex of East Molokai Volcano is exposed in Pelekunu and Wailau Stream valleys, and is composed of stocks, plugs, crater fills, ponded lavas, and talus and fault breccias cut by dike swarms (Stearns and Macdonald, 1947). Much of the caldera complex is covered with older alluvium. The rocks of the caldera complex contain calcite, quartz, and secondary minerals deposited by hydrothermal action (Stearns and Macdonald, 1947, p. 19). Langenheim and Clague (1987) show the generalized location of the caldera complex of East Molokai Volcano (fig. 4).

Stearns and Macdonald (1947) mapped numerous vent features, including cinder and spatter cones, along the western and southern flanks of the East Molokai Volcano (fig. 4). Additional vent features associated with the lower member of the East Molokai Volcano are probably hidden by younger flows. Many of these features do not appear to lie along the trends of the two primary rift zones of the volcano, which may indicate that (1) a marginal dike zone exists or (2) more than two primary rift zones exist.

\section{Hydraulic Conductivity}

In general, the average hydraulic conductivity of a rift zone decreases as the number of dike intrusions within the rift zone increases. In addition, hydraulic conductivity is expected to be higher in a direction along the strike of the dikes rather than perpendicular to the strike. Although the geometry and the local-scale hydrologic effects of the feeder dikes associated with the scattered vent features of East Molokai Volcano are not known, these feeder dikes must intrude the aquifer to some extent and probably lower the overall permeability of the aquifer. 


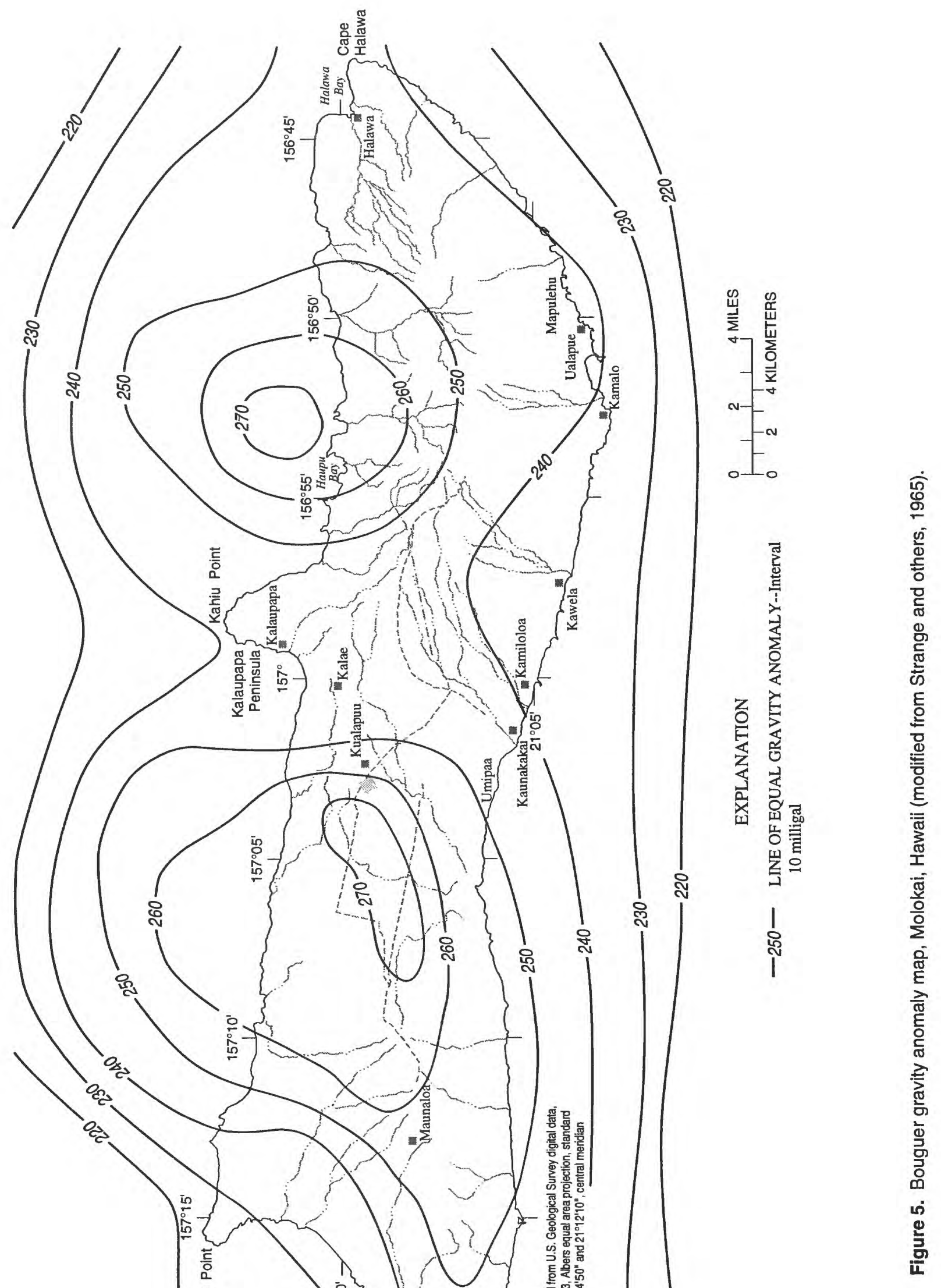


On the basis of a numerical model analysis, Meyer and Souza (1995) suggest that the average, effective hydraulic conductivity of a dike complex ranges from about 0.01 to $0.1 \mathrm{ft} / \mathrm{d}$. These values reflect the influence of both the intrusive dikes as well as the extrusive lava between dikes. The hydraulic conductivity of the intrusive dike material was estimated to range from $10^{-5}$ to $10^{-2} \mathrm{ft} / \mathrm{d}$ (Meyer and Souza, 1995). An aquifer test was conducted in 1961 in the dike complex near Waikolu Stream valley and later analyzed by Williams and Soroos (1973), who estimated aquifer transmissivity (the product of hydraulic conductivity and effective aquifer thickness) to be between $1.6 \times 10^{4}$ and $3.4 \times 10^{4}$ $\mathrm{ft}^{2} / \mathrm{d}$.

\section{Coastal Deposits}

Along southern Molokai, a coral reef extends from the coast to about $1 \mathrm{mi}$ offshore, and limestone has also been described in a geologic log from a well near the southern coast of the island (Lindgren, 1903). In addition, along the southern shore of East Molokai Volcano and the Hoolehua Plain, an apron of alluvium has formed by deposition of eroded soil. Neither geologic logs nor geophysical survey data are available to define the thickness of the coastal deposits off the southern coast of Molokai. However, coastal-deposit thickness can be estimated as the difference in altitude between the offshore-projected surface of the volcano, obtained using slopes corresponding to measured dips of the lava flows, and the measured bathymetry (see for example National Oceanic and Atmospheric Administration, 1989 and 1993). Along the southern coast, lava flows dip about $10^{\circ}$ on East Molokai Volcano and $4^{\circ}$ on West Molokai Volcano. Off the northern coast of Molokai, only a thin veneer of recent sediments exists (Mathewson, 1970).

Data do not exist to estimate the hydraulic conductivity of the coastal deposits of southern Molokai. These coastal deposits are similar to some of those found on Oahu. Coastal deposits and underlying weathered volcanic rocks impede the seaward discharge of freshwater on Oahu (Souza and Voss, 1987) and probably also do on southern Molokai. The permeability of the interbedded coastal deposits may vary widely, from low-permeability compacted alluvium to cavernous limestone deposits. Wentworth (1938) estimated the hydraulic conductivity of alluvium and weathered alluvium core samples from Oahu to range from about $0.01 \mathrm{ft} / \mathrm{d}$ to 1.0 $\mathrm{ft} / \mathrm{d}$. Data from Oahu indicate that the hydraulic conductivity of limestone units may range from 2 to $30,000 \mathrm{ft} / \mathrm{d}$ (Camp Dresser and McKee, 1993).

\section{Faults}

The northeast side of West Molokai Volcano is terminated in a set of fault scarps, 100 to $500 \mathrm{ft}$ high (Stearns and Macdonald, 1947). The downthrown part of the volcano is generally to the northeast, and lies under the Hoolehua Plain, buried by lavas from the East Molokai Volcano. The northern part of East Molokai Volcano was removed by the Wailau debris avalanche (Moore and others, 1989). The fault scarp associated with this avalanche has been modified by wave erosion to the present sea cliff of northern Molokai. In northeastern Molokai, faults are numerous near the mouth of Pelekunu Stream valley and in the cliffs bounding Haupu Bay (Stearns and Macdonald, 1947). No data exist to evaluate the hydrologic effects of the faults on ground-water flow.

\section{HYDROLOGY}

Precipitation is the source of all freshwater on Molokai. The precipitation either (1) runs off, (2) evaporates or is transpired by vegetation, or (3) recharges the ground-water system. Water that recharges the groundwater system flows from zones of higher to lower hydraulic head, as measured by water levels. Ground water is either withdrawn from wells or discharges to streams, the ocean, or other surface-water bodies.

\section{Ground-Water Recharge}

Ground-water recharge on Molokai was estimated to be $144 \mathrm{Mgal} / \mathrm{d}$ on the basis of an annual water budget (State of Hawaii, 1990). Shade (in press) estimated that ground-water recharge was $188.6 \mathrm{Mgal} / \mathrm{d}$ for natural vegetation conditions. This represents an average of about $15 \mathrm{in} / \mathrm{yr}$ over the island. However, recharge varies greatly areally from a minimum of near zero in/yr in western Molokai to a maximum of about $100 \mathrm{in} / \mathrm{yr}$ in northeastern Molokai. The estimate of $188.6 \mathrm{Mgal} / \mathrm{d}$ (Shade, in press) represents the average of two different monthly water-budget computation methods. The two computation methods differ by the order in which 
recharge and evapotranspiration are taken into account in the water budget. Each water-budget computation method produced a recharge estimate that differed from the average value by about 25 percent.

Compared to natural vegetation, pineapple can increase recharge to an area because evapotranspiration from unirrigated pineapple is less than evapotranspiration from natural vegetation. On the basis of lysimeter measurements, Ekern (1965) estimated that pineapple evapotranspiration at full canopy is only 20 percent of pan evaporation. Giambelluca (1983) used this information to estimate that pineapple cultivation increased recharge by $15.89 \mathrm{in} / \mathrm{yr}$ over that of natural vegetation in southern Oahu during the period from 1946 through 1975.

The areas of pineapple cultivation during the period 1954-61, which represents the middle of the pineapple-cultivation period on Molokai, were in central and western Molokai (fig. 6). The period 1954-61 is used to develop the ground-water model in the section of this report titled "Development of Ground-Water Flow Model." During this period, some of the pineapple fields in the Kualapuu area were irrigated with groundwater from wells 0901-01 and 0902-01 (fig. 6) or surface water from DHHL or Molokai Ranch sources. During peak months, irrigation totalled about $0.8 \mathrm{Mgal} / \mathrm{d}$ (fig. 7). Pineapple fields on Hawaiian Homes Commission lands were assumed to be unirrigated (Austin and Stearns, 1954). In addition, pineapple fields in western Molokai near Maunaloa town were generally unirrigated (Baker, 1960; State of Hawaii, 1966, p. 31).

The two monthly water-budget methods described by Shade (in press) were modified and used to estimate the effects of pineapple cultivation on recharge during 1954-61. For a pineapple plant root depth of 12 in.

(Giambelluca, 1983), and assuming that none of the irrigation water runs off, average annual recharge in areas of pineapple cultivation for 1954-61 was estimated to be $17.4 \mathrm{Mgal} / \mathrm{d}$, and for the entire island $201.3 \mathrm{Mgal} / \mathrm{d}$. These recharge estimates represent the average of the two monthly water-budget computation methods. For the areas previously occupied by pineapple fields (fig. 6), the recharge for natural vegetation conditions was estimated to be $4.7 \mathrm{Mgal} / \mathrm{d}$ (Shade, in press), which is $12.7 \mathrm{Mgal} / \mathrm{d}$ less than the estimate for pineapple. Giambelluca and others (1996) suggest that the uncertainty in daily water-budget recharge estimates for pineapple cover, because of uncertainty in the water-budget components, such as rainfall, evapotranspiration, or runoff, is 58 percent of the mean value.

\section{Ground-Water Withdrawals}

Most of the ground-water withdrawn on Molokai is from wells in the Kualapuu area, the south shore of eastern Molokai, and the dike complex in northeastern Molokai (fig. 8). The reported annual mean pumpage for Molokai during 1996 was $4.336 \mathrm{Mgal} / \mathrm{d}$ (computed from data supplied by Neal Fujii, CWRM, written commun., 1997).

Five production wells (0801-01 to -03, 0901-01, and 0902-01) have been drilled in the Kualapuu area for either irrigation or domestic use (fig. 8). Wells 0902-01 and 0901-01, drilled in 1946 and 1950, respectively, were originally used to irrigate pineapple fields in the Hoolehua Plain area. Well 0902-01 was abandoned in 1964 when water from the Molokai Irrigation System became available. Since 1976, water from well 0901-01 has been used for domestic and irrigation purposes in western Molokai. Prior to the completion of the Molokai Irrigation System tunnel, combined withdrawals from wells 0901-01 and 0902-01 varied seasonally from near zero to about $1.0 \mathrm{Mgal} / \mathrm{d}$ (fig. 9). DHHL wells 0801-01 and 0801-02 (fig. 8) were drilled in 1948 and 1979 , respectively, and Maui County well 0801-03 was drilled in 1987. Monthly mean withdrawal rates from wells 0801-01 to -03 have remained below $1 \mathrm{Mgal} / \mathrm{d}$ (fig. 9). During 1996, annual mean withdrawal from the four active wells in the Kualapuu area was 2.029 $\mathrm{Mgal} / \mathrm{d}$.

Along the south shore of eastern Molokai, groundwater withdrawals are mainly from two Maui-type wells (consisting of a shaft excavated to or below the water table, and one or more infiltration tunnels extending outward from the shaft); one near Kawela (0457-01) completed in 1921, and the other near Ualapue (044901) completed in 1936 (fig. 8). During 1996, annual mean withdrawals from wells 0457-01 and 0449-01 were 0.398 and $0.204 \mathrm{Mgal} / \mathrm{d}$, respectively. Total unreported withdrawals from several other drilled wells and numerous shallow dug wells along the southern coast of Molokai are probably small.

Three production wells (0855-01 to -03) (fig. 8) drilled in 1961 withdraw water from the dike complex in northeastern Molokai. Water from these wells enters the Molokai Irrigation System. Monthly mean combined withdrawal from these three wells is about 1 Mgal/d (fig. 9). During 1996, annual mean combined withdrawal was $1.438 \mathrm{Mgal} / \mathrm{d}$. 


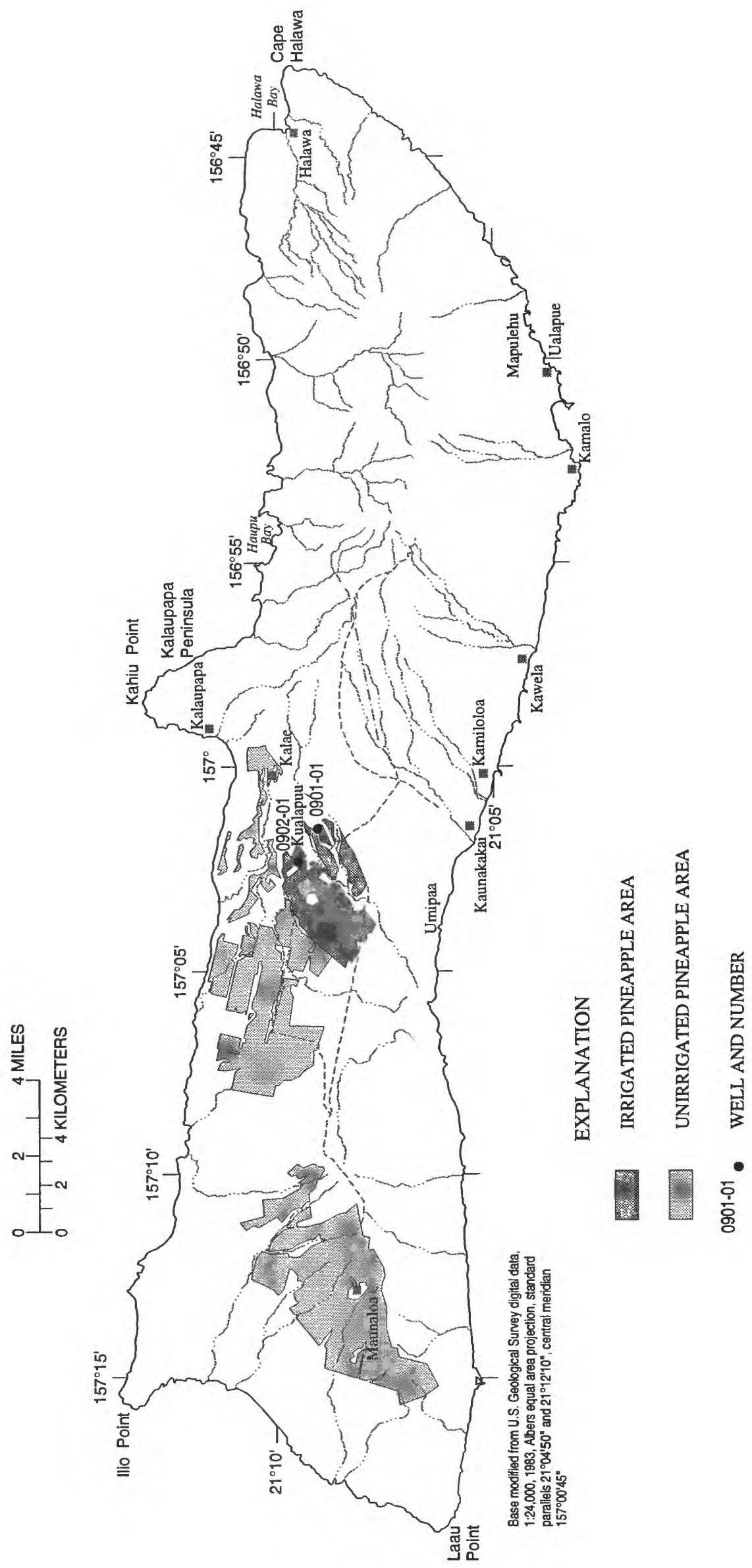

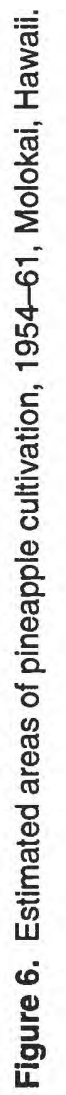




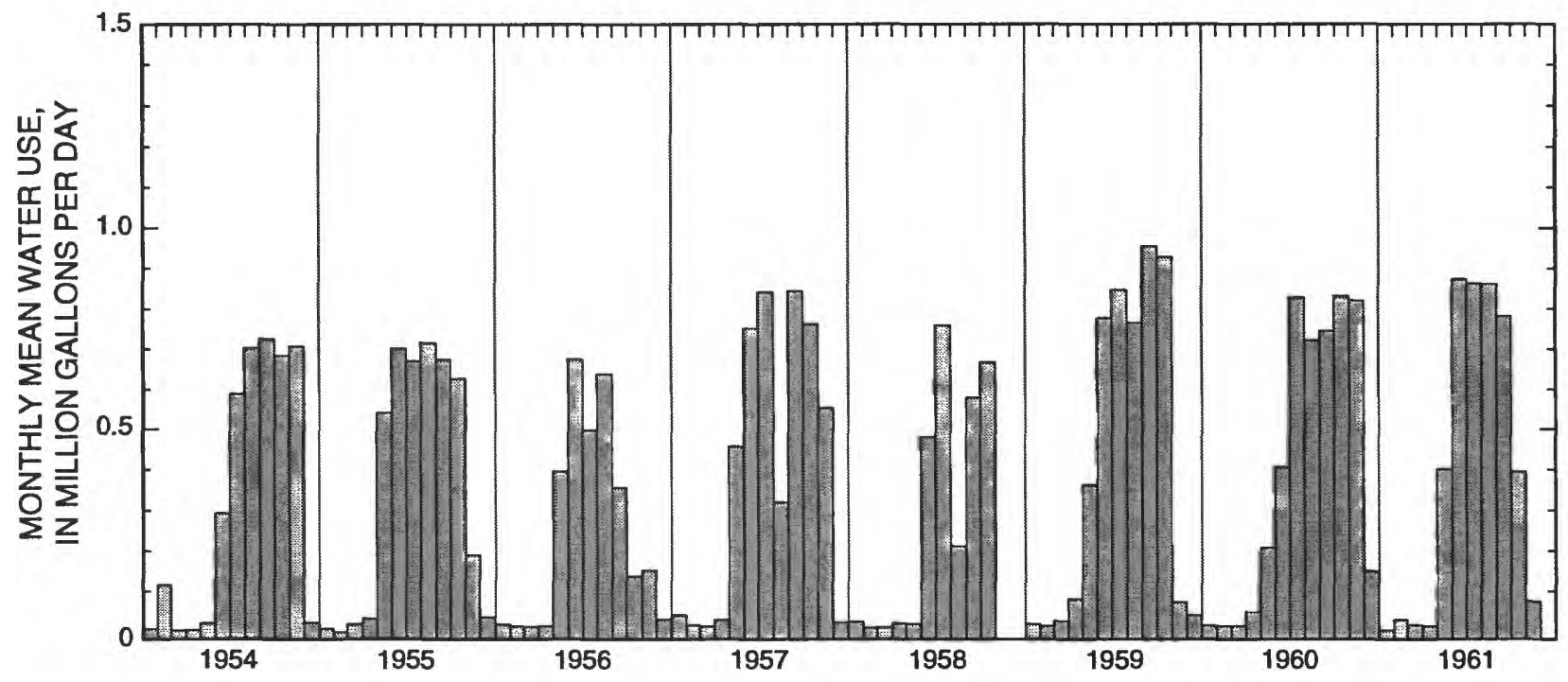

Figure 7. Monthly mean water use for pineapple irrigation in the Kualapuu area, 1954-61, Molokai, Hawaii.

Because parts of the Molokai Irrigation System tunnel are below the water table, ground water discharges directly into the tunnel by gravity. During periods in which the tunnel was not used to convey water from wells 0855-01 to -03 to west or central Molokai, direct discharge of ground water to the tunnel was 1.822 Mgal/d.

\section{Streamflow}

Streams on Molokai have steep gradients in the mountainous, high-rainfall regions and flat gradients near the coast. No perennial streams exist in western Molokai or the central Hoolehua Plain. In general, streams in the windward, northeastern valleys of Molokai are perennial throughout most of their lengths. Most streams that drain to the southern coast of East Molokai Volcano are perennial only in the upper reaches where rainfall is persistent or where water is drained from marsh areas or springs. These streams are generally perennial only where they flow over lavas of the upper member of the East Molokai Volcanics. Where streams flow over the more permeable lavas of the lower member, surface water is more readily lost to infiltration (Stearns and Macdonald, 1947, p. 47).

Daily streamflow records are available at nine stream-gaging stations on streams in the windward, northeastern valleys of Molokai (fig. 10). Streamflow consists of direct runoff of rainfall and baseflow. The latter is presumed to represent ground-water discharge.

To estimate the baseflow component of streamflow, a computerized baseflow separation method, known as the BFI program (Wahl and Wahl, 1995), was used. Two parameters, $\mathrm{N}$ (number of days) and $\mathbf{f}$ (turning point test factor) must be assigned values in the model. The model divides the daily streamflow record into nonoverlapping $\mathrm{N}$-day periods and determines the minimum flow within each $\mathrm{N}$-day window. If the minimum flow within a given N-day window is less than $\mathbf{f}$ times the adjacent minimums, then the central window minimum is made a turning point on the baseflow hydrograph. Wahl and Wahl (1995) recommend a value of 0.9 for the turning point test factor for most applications.

The sum of the estimated average annual baseflow in the gaged streams is $38.8 \mathrm{Mgal} / \mathrm{d}$ (table 1), which represents only a part of the total baseflow on Molokai. The total is unknown because not all streams are gaged at their mouths. At station 16408000, Waikolu Stream, only data prior to 1961 were used because of diversions after November 1960. Baseflow at gaging station 16403900 was not included in the $38.8 \mathrm{Mgal} / \mathrm{d}$ baseflow estimate because flow measured at this gaging station is included in the baseflow estimate at downstream station 16404000. 


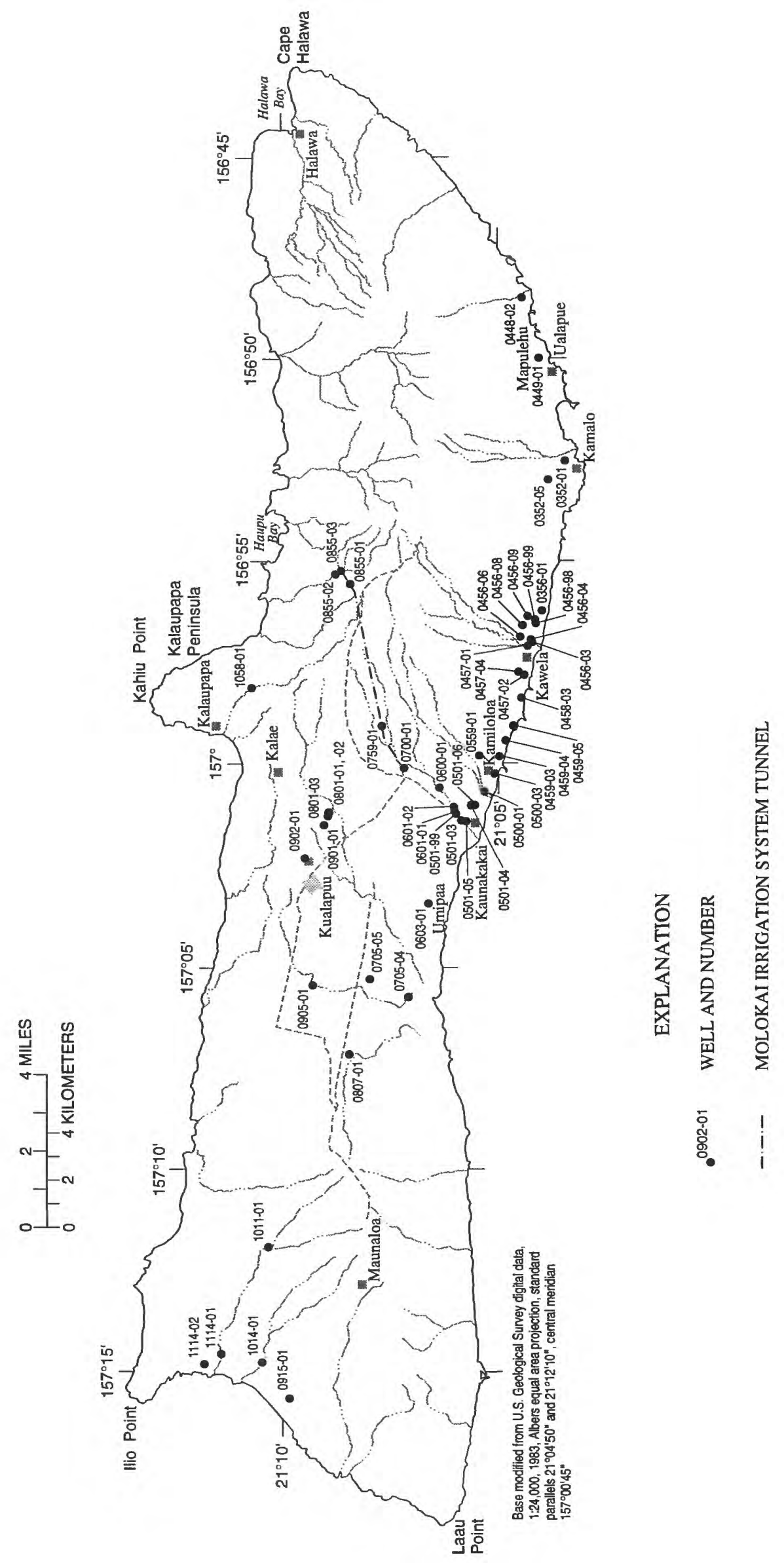

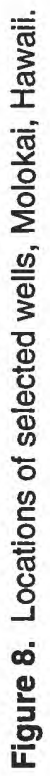



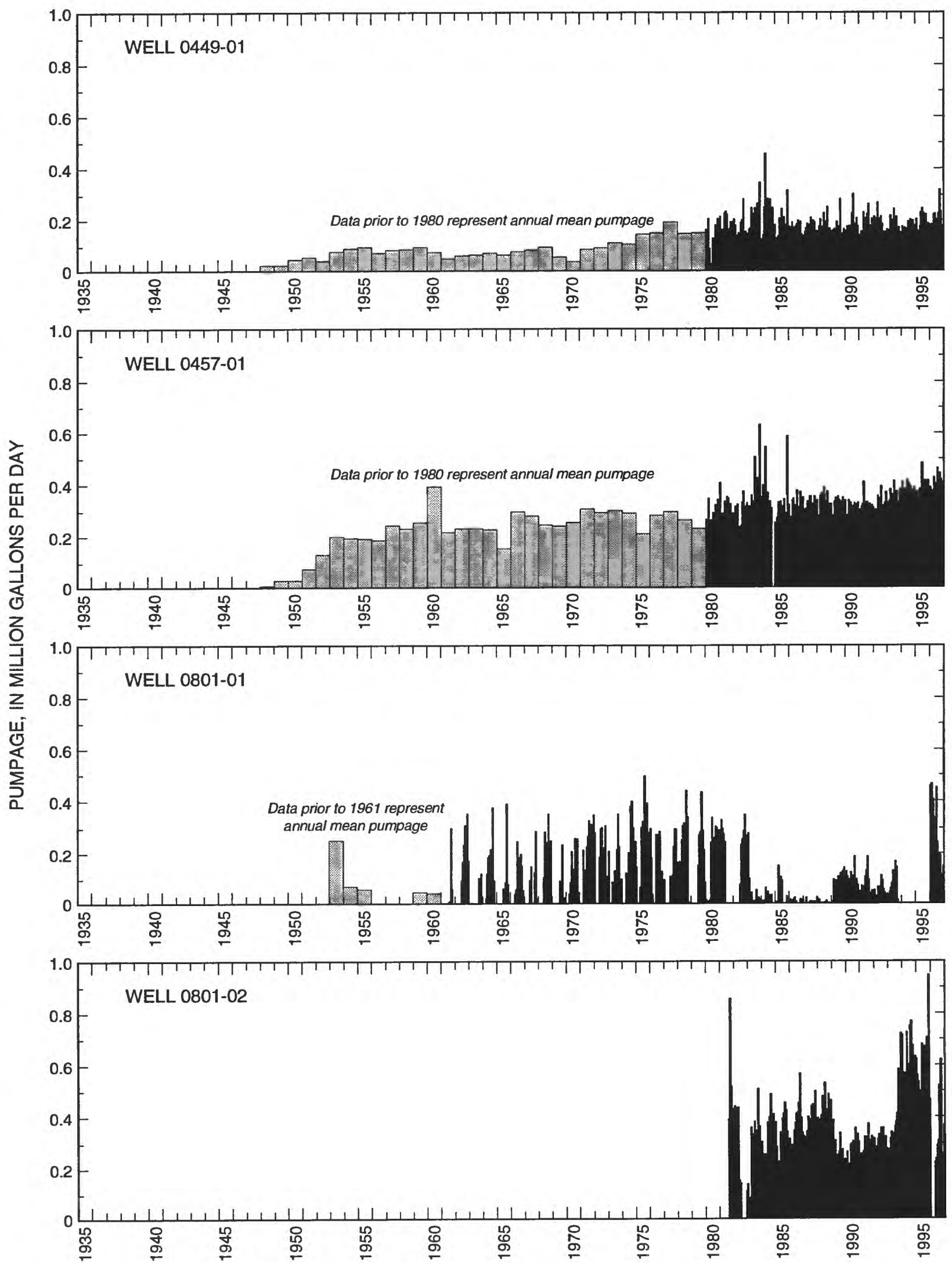

Figure 9. Monthly or annual mean pumpage from selected wells, Molokai, Hawaii. 

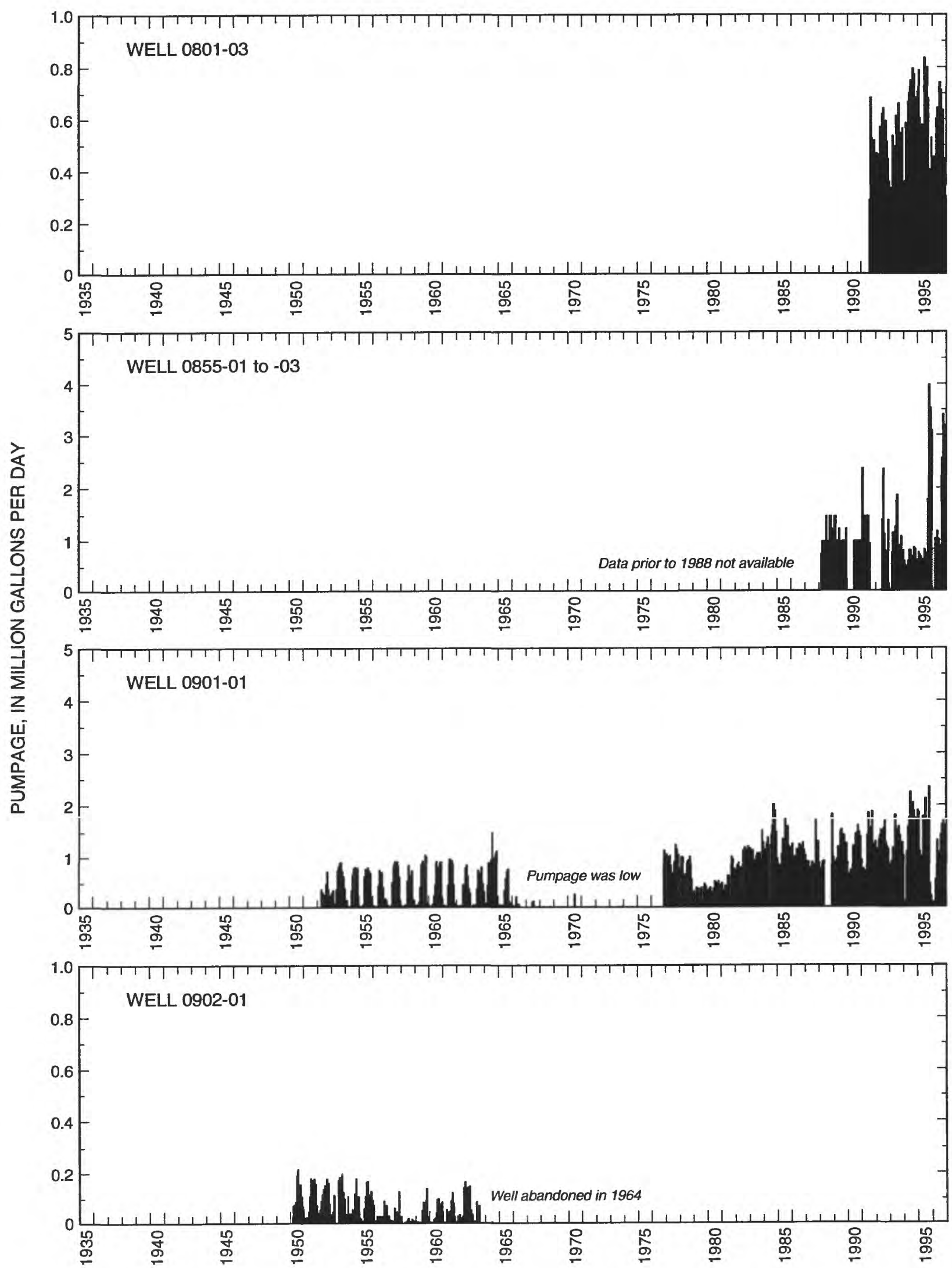

Figure 9. Monthly or annual mean pumpage from selected wells, Molokai, Hawaii--Continued. 


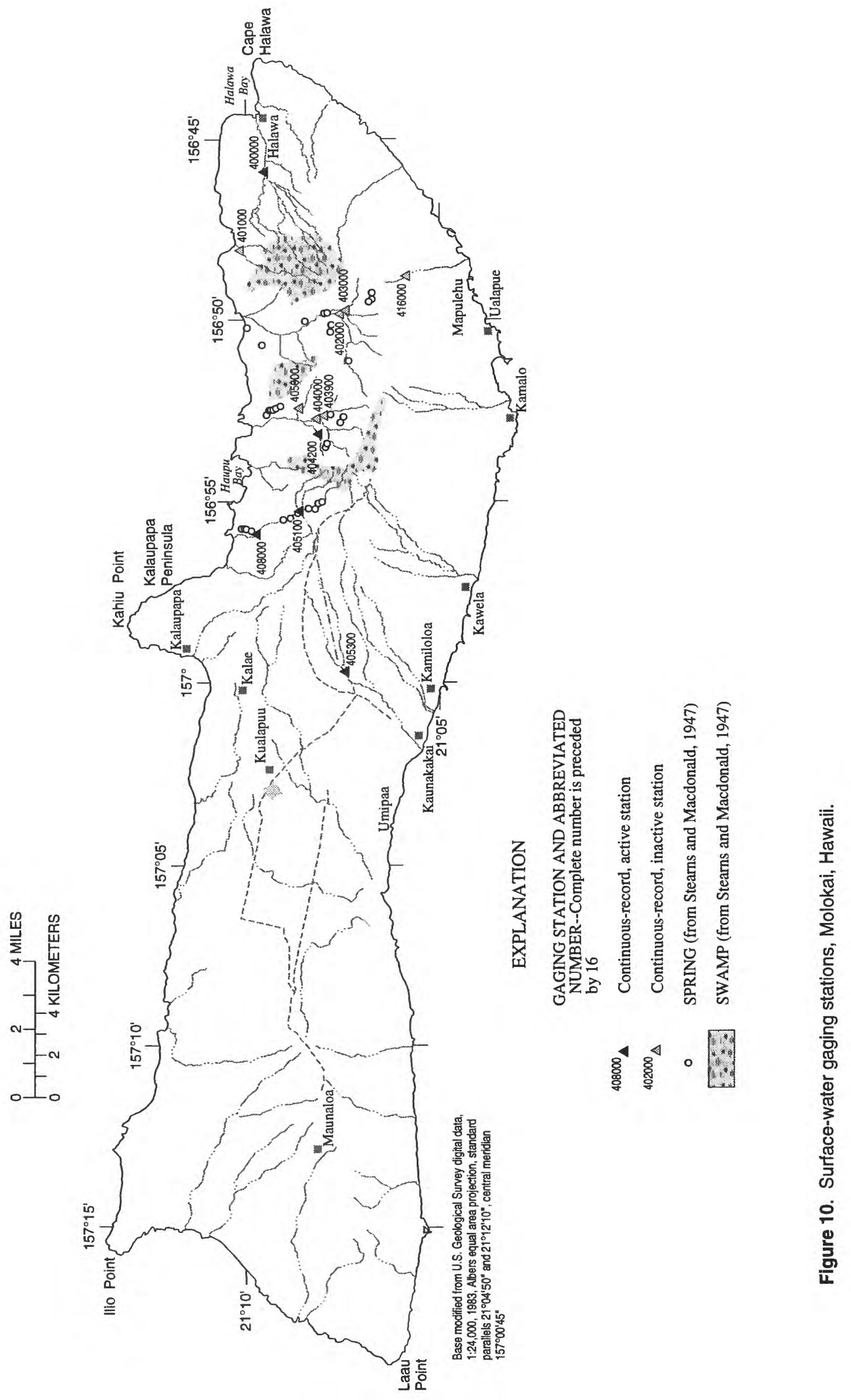


Table 1. Estimated baseflow for northeastern Molokai streams, Hawaii

[BFI, base flow index program (Wahl and Wahl, 1995); Mgal/d, million gallons per day; --, no data]

\begin{tabular}{|c|c|c|c|c|c|c|c|c|}
\hline Station & Station name & $\begin{array}{l}\text { Complete years of } \\
\text { record used in BFI } \\
\text { program }\end{array}$ & $\begin{array}{c}\text { BFI } \\
\text { parameter } \\
\text { (N) }\end{array}$ & $\begin{array}{c}\text { BFI } \\
\text { parameter } \\
\text { (f) }\end{array}$ & $\begin{array}{c}\text { Average } \\
\text { streamflow } \\
\text { (Mgal/d) }\end{array}$ & $\begin{array}{c}\text { Average } \\
\text { baseflow } \\
\text { for 1954- } \\
61 \text { data } \\
\text { (Mgal/d) }\end{array}$ & $\begin{array}{c}\text { Average } \\
\text { baseflow, } \\
\text { entire } \\
\text { period of } \\
\text { record } \\
\text { (Mgal/d) }\end{array}$ & $\begin{array}{c}1954-61 \\
\text { model- } \\
\text { calcula- } \\
\text { ted } \\
\text { baseflow } \\
\text { (Mgal/d) }\end{array}$ \\
\hline 16400000 & Halawa Stream near Halawa & $\begin{array}{l}1919,1922-32,1939- \\
96\end{array}$ & 4 & 0.9 & 19.5 & 5.7 & 5.2 & 0 \\
\hline 16401000 & Papalaua Stream near Pukoo & $1922-29$ & 3 & 0.9 & 13.8 & -- & 4.1 & 2.3 \\
\hline 16402000 & Pulena Stream near Wailau & $1921-28,1939-57$ & 5 & 0.9 & 22.2 & 8.4 & 8.9 & 11.2 \\
\hline 16403000 & Waiakeakua Stream near Wailau & $1921-29,1939-57$ & 5 & 0.9 & 7.5 & 3.5 & 3.8 & 2.8 \\
\hline 16403900 & Kawainui Stream near Pelekunu & $1970-80,1996$ & 5 & 0.9 & 5.1 & -- & 2.2 & 1.9 \\
\hline 16404000 & Pelekunu Stream near Pelekunu & $\begin{array}{l}1921-29,1939-47 \\
1950-57,1973-82\end{array}$ & 5 & 0.9 & 10.6 & 5.0 & 4.6 & 4.6 \\
\hline 16404200 & Pilipililau Stream near Pelekunu & $1970-96$ & 3 & 0.9 & 1.0 & -- & 0.7 & 0.8 \\
\hline 16405000 & Lanipuni Stream near Pelekunu & $1921-29,1939-57$ & 4 & 0.9 & 9.1 & 4.0 & 4.3 & 2.8 \\
\hline 16408000 & $\begin{array}{l}\text { Waikolu Stream below pipeline } \\
\text { crossing near Kalaupapa }\end{array}$ & $\begin{array}{l}1922-30,1939-48, \\
1950-60\end{array}$ & 3 & 0.9 & 12.3 & 7.5 & 7.2 & 7.3 \\
\hline
\end{tabular}

\section{Ground-Water Levels}

Ground-water flow rates and directions are difficult to measure directly, and are usually inferred from water-levels. Ground-water levels also are an indicator of changes in recharge or withdrawals from the groundwater system, and can be an indicator of freshwater-lens thickness.

\section{Spatial Distribution}

Measured water levels are available primarily at wells along the southern coast and in the central plain area (figs. 11 and 12, table 2). In the vicinity of Kualapuu, water levels are generally about 10 to $12 \mathrm{ft}$ above sea level. Along the south shore, water levels are generally 1 to $3 \mathrm{ft}$ above sea level between Umipaa and Kawela, and 4 to $5 \mathrm{ft}$ above sea level between Kamalo and Mapulehu. Anthony (1995) has attributed the higher water levels between Kamalo and Mapulehu to (1) a shorter ground-water flow path between the crest of the mountains and the coast, (2) a greater groundwater flow rate, or (3) a greater thickness of low permeability sedimentary deposits near the coast relative to the area between Umipaa and Kawela. In addition, it is possible that the overall permeability of the volcanic rocks may be lower in the area between Kamalo and Mapulehu relative to the area between Umipaa and Kawela.

Within the northwest rift zone of the East Molokai Volcano near Waikolu Stream valley, water levels at wells $0855-01$ to -03 were about $900 \mathrm{ft}$ above sea level in 1961. At the northern margin of the dike complex, near Kalaupapa Peninsula, the water level at well 105801 was reported to be $9 \mathrm{ft}$ above sea level.

The 9-ft water level at well 1058-01 probably represents an upper limit for the water-table altitude in the dike-free Kalaupapa Volcanics. Results from an electrical resistivity survey indicated that the lens in the Kalaupapa Volcanics was thin (Takasaki, 1986).

In the West Molokai Volcanics, the water level at well 1011-01 was reported by Stearns and Macdonald (1947, p. 61) to be $5.6 \mathrm{ft}$ above sea level in 1946.

The general distribution of water levels on Molokai, from measurements taken over a period of about 58 years, is shown in figure 11. A detailed contour map of water levels for the entire island cannot be drawn on the basis of existing well data. MacCarthy (1941) used electrical resistivity measurements in conjunction with the Ghyben-Herzberg principle to estimate the altitude of the water table in western Molokai (fig. 11). MacCarthy (1941) estimated that the water-table altitude in western Molokai ranges from about 1 to $14 \mathrm{ft}$ above sea level.

\section{Temporal Variation}

At many wells, only single water-level measurements are available (table 2), and the reference datums used for some of these wells are questionable. At 12 wells, water-level measurements are available for a period of at least 7 years. Water-level hydrographs orig- 


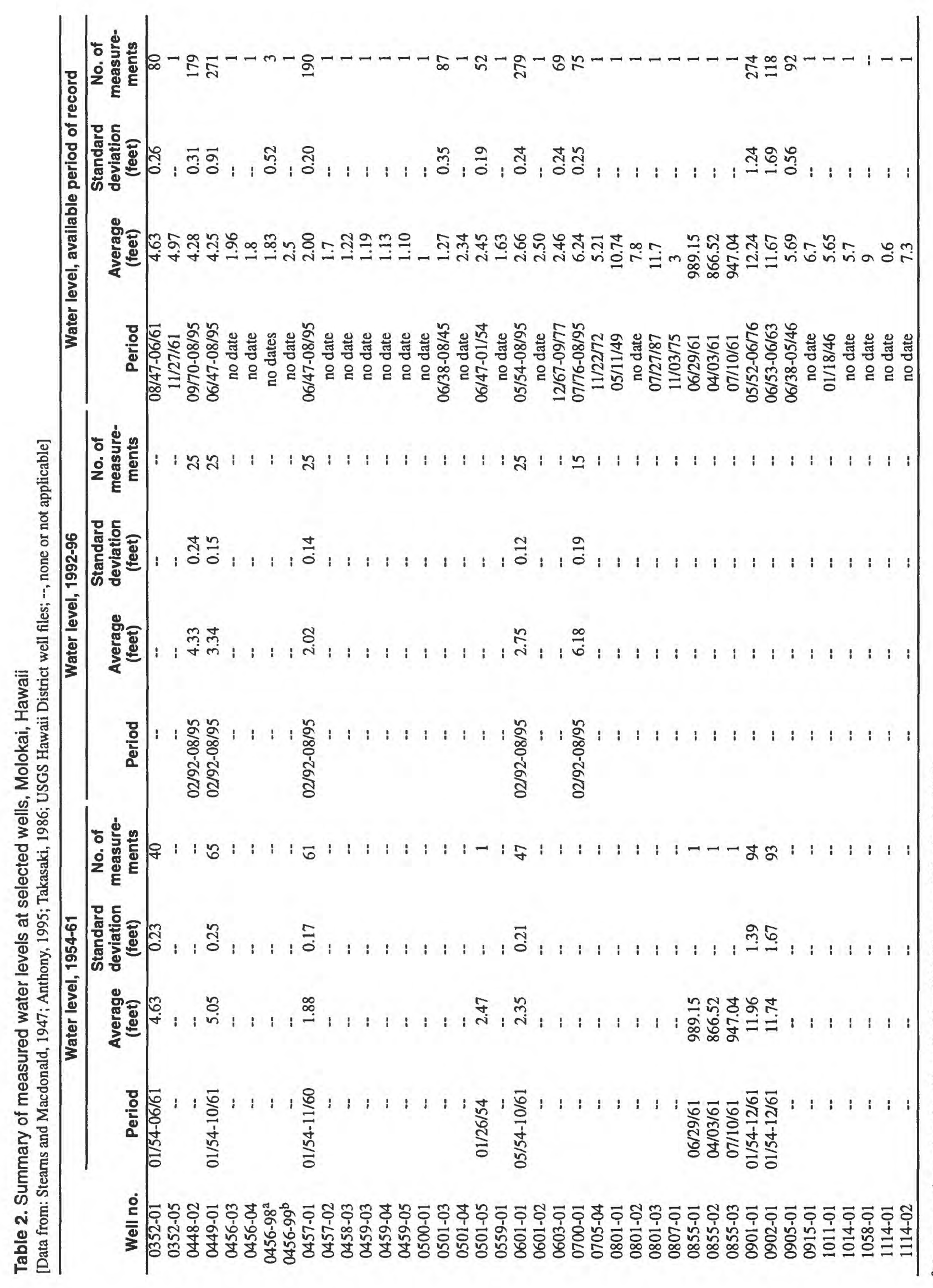

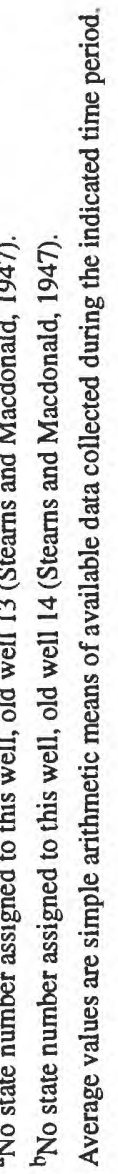




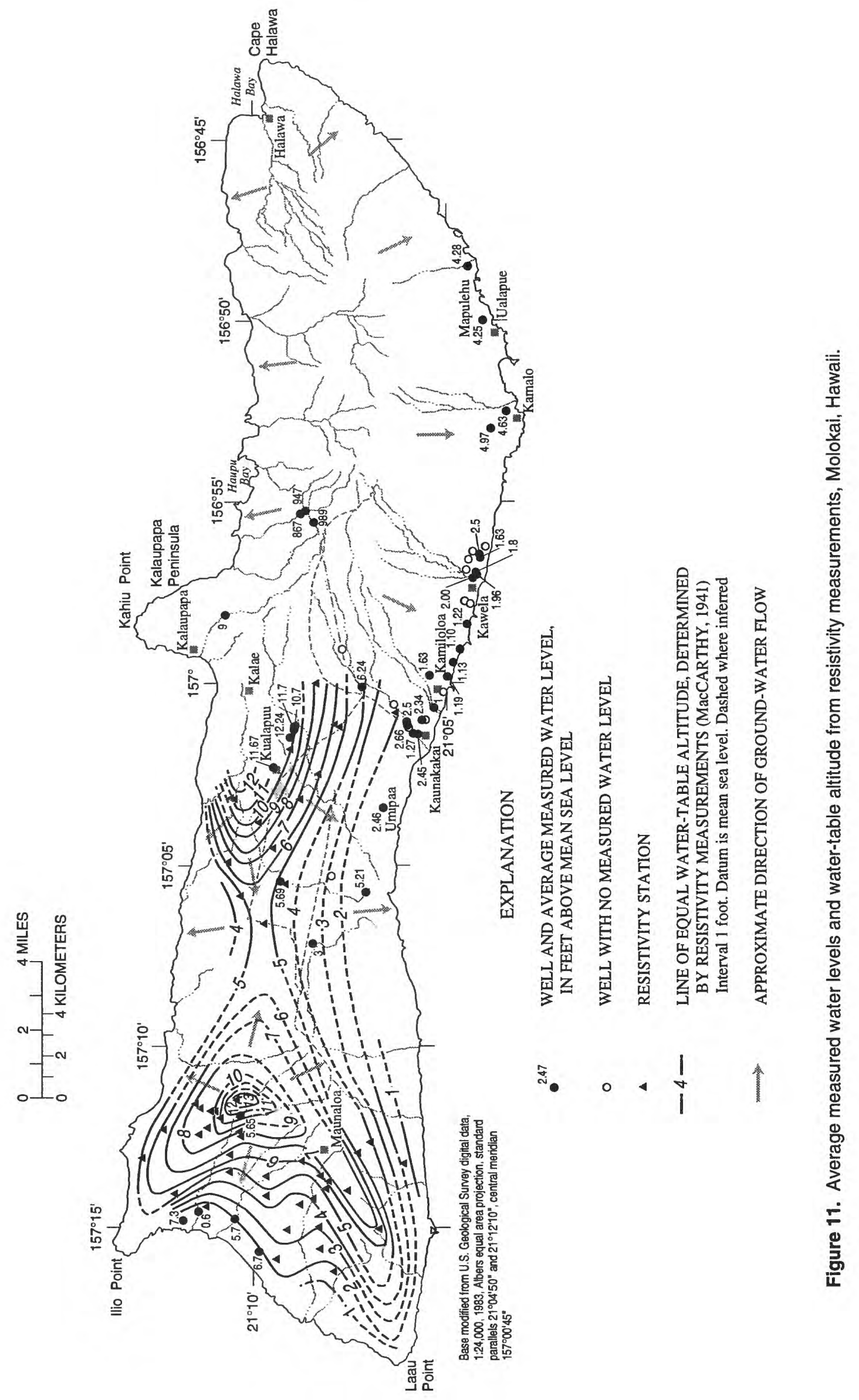




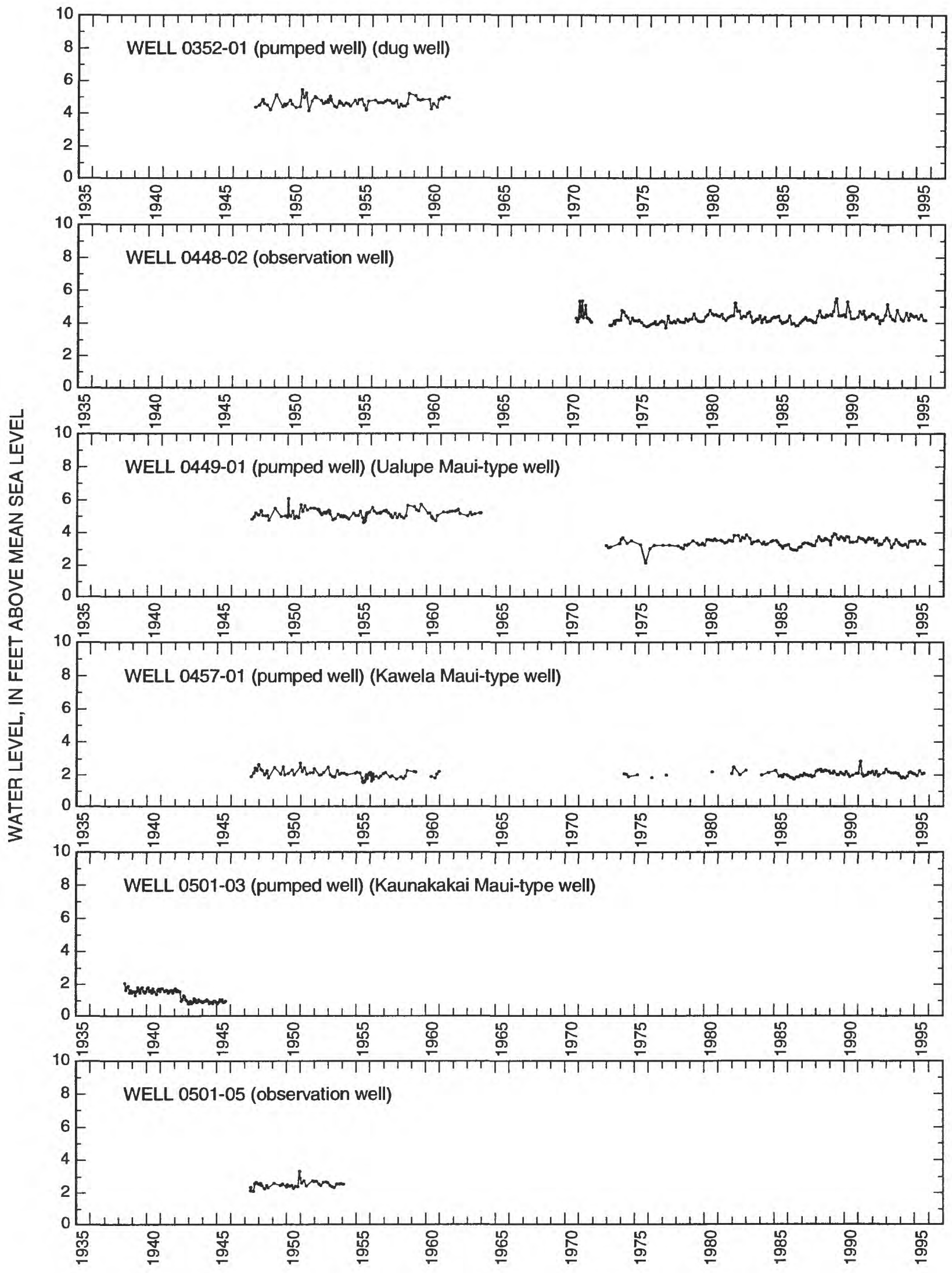

Figure 12. Water levels from selected wells, Molokai, Hawaii (data points not connected for data gaps exceeding one year). 


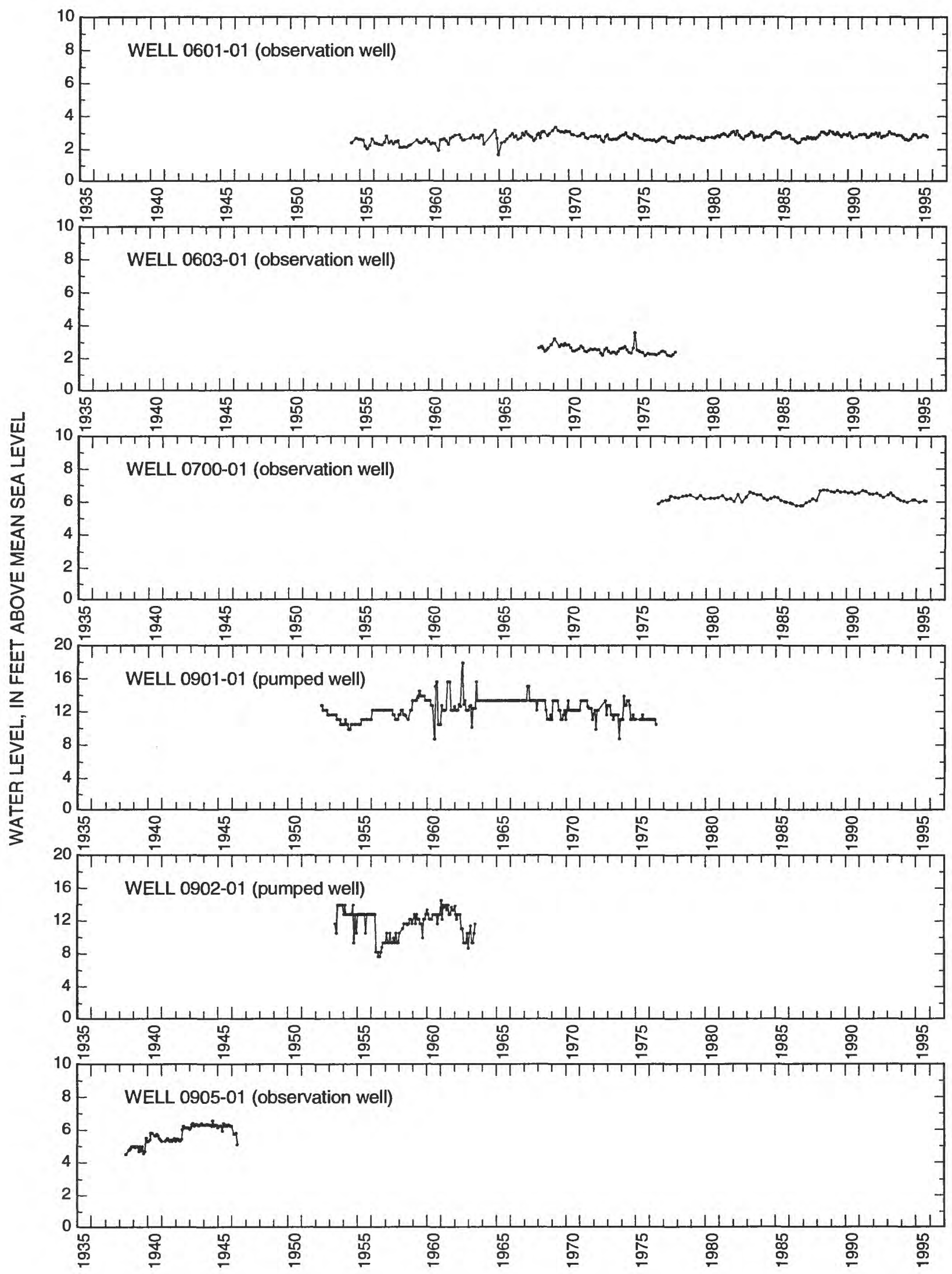

Figure 12. Water levels from selected wells, Molokai, Hawaii (data points not connected for data gaps exceeding one year)--Continued. 
inally presented by Anthony (1995) were updated for this study to reflect data collected since 1992 (fig. 12). The collective time period covered by the hydrographs is from 1938 to 1995 . The seasonal and interannual variations in water levels appear to be less than a foot at most wells. In general, the hydrographs show no longterm trends in water levels. At well 0601-01, for instance, water levels have remained relatively steady over a period of more than 40 years since 1954 .

At well 0449-01, water levels appear to drop about $2 \mathrm{ft}$ between 1963 and 1972. This drop most likely reflects a change in datum rather than a change in water level. Although the absolute water levels at this well are uncertain, the data do not indicate any long-term trends.

The hydrographs for wells 0901-01 and 0902-01, both in the Kualapuu area, show relatively large variations in water levels from one measurement to the next. These large variations could be caused by pumping but are most likely associated with the inaccuracy of the pressure measurements made with an air-line device. Despite this, the water levels at wells 0901-01 and 0902-01 do not indicate a trend.

\section{Chloride Concentration}

Chloride concentration is generally used as an indicator of saltwater intrusion into the ground-water system. Long-term records of chloride concentrations are available for six pumped wells and three observations wells (fig. 13) (Anthony, 1995). Chloride concentrations in water samples are generally less than 750 $\mathrm{mg} / \mathrm{L}$ in all of the nine wells, and less than $150 \mathrm{mg} / \mathrm{L}$ in six of the wells. For comparison, the chloride concentration of rainfall is typically less than $20 \mathrm{mg} / \mathrm{L}$ (Swain, 1973). Although chloride concentrations at wells can change in response to changes in withdrawals and recharge, existing data do not indicate a significant long-term change in chloride concentration.

Observation wells 0601-01 and 0603-01 are located along the south shore of eastern Molokai. At well 0603-01 near Umipaa, chloride concentration has ranged from 260 to $750 \mathrm{mg} / \mathrm{L}$ during $1967-77$. At well 0601-01 near Kaunakakai, the temporal pattern of chloride concentration shows a distinct change starting in 1966 (fig. 13). During 1954-66, the chloride concentration of sampled water at well 0601-01 averaged 93 $\mathrm{mg} / \mathrm{L}$, with a seasonal variation of about $100 \mathrm{mg} / \mathrm{L}$. Since 1966, the chloride concentration of sampled water has averaged about $25 \mathrm{mg} / \mathrm{L}$ with a seasonal variation of about $20 \mathrm{mg} / \mathrm{L}$. This decrease in average and seasonal variation of chloride concentration has been attributed by Anthony (1995) to: (1) a change in the depth from which water samples were collected in the $10-\mathrm{ft}$ water column, (2) the discontinued use of a nearby pumped well, (3) the periodic discharge of water from the west portal of the Molokai Irrigation tunnel into Kaunakakai Gulch since the early 1960's, or (4) changes in rainfall (Anthony, 1995, p. 24). Maui-type wells 0449-01 and 0457-01 are also located along the south shore of eastern Molokai. At both of these Mauitype wells, chloride concentrations of the pumped water have remained below $200 \mathrm{mg} / \mathrm{L}$.

The chloride concentration of water from wells in the Kualapuu area, where water levels are 10 to $12 \mathrm{ft}$ above sea level, has generally been below $200 \mathrm{mg} / \mathrm{L}$ except at well 0902-01. During 1950-61, the chloride concentration of water withdrawn from well 0902-01 ranged from 252 to $430 \mathrm{mg} / \mathrm{L}$. In 1995, wells 0801-01, 0801-02, 0801-03, and 0901-01 in the Kualapuu area all produced water with a chloride concentration less than $200 \mathrm{mg} / \mathrm{L}$.

\section{Ground-Water Flow System}

Ground-water recharge by direct infiltration of rainfall occurs over much of Molokai. Over West Molokai Volcano and the Hoolehua Plain, however, groundwater recharge rates are low because of the low rainfall and high evaporation rates. The area of greatest recharge lies near the topographic peak of East Molokai Volcano, where rainfall is greatest.

Fresh ground water on Molokai occurs in two main forms: (1) as impounded high-level ground water within volcanic rift zones, and (2) as a freshwater lens floating on denser, underlying saltwater. Stearns and Macdonald (1947) also suggest that perched water exists on Molokai.

\section{High-Level Ground Water}

Within the rift zones of the East Molokai Volcano, fresh ground-water is impounded to high levels in the volcanic rocks between low-permeability dikes. In the valleys of northeast Molokai, the presence of springs indicates that ground-water in the dike complex is probably impounded to altitudes greater than $2,000 \mathrm{ft}$ above sea level (Stearns and Macdonald, 1947, p. 75). The 


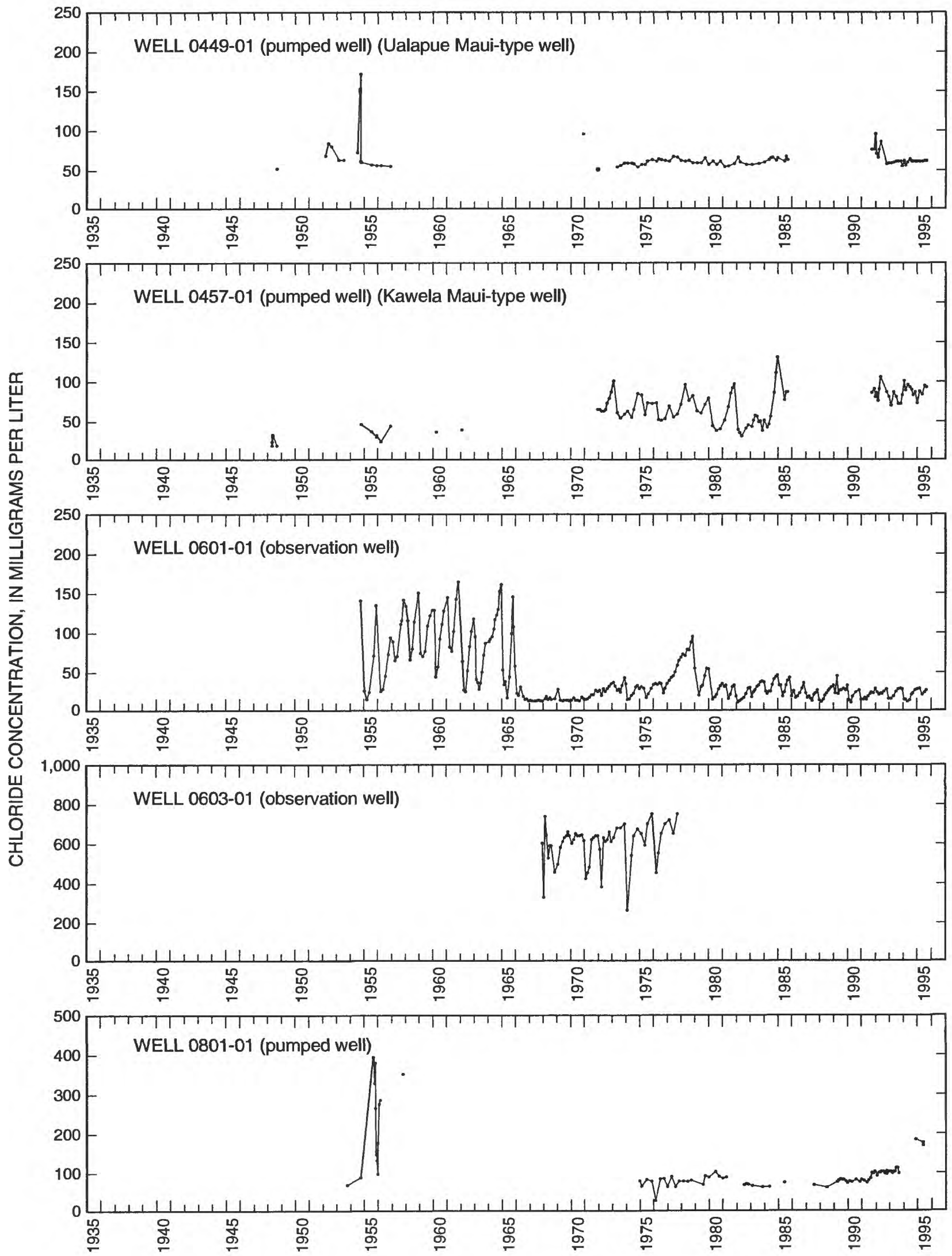

Figure 13. Chloride concentrations of ground water from selected wells, Molokai, Hawaii (data points not connected for data gaps exceeding one year). 


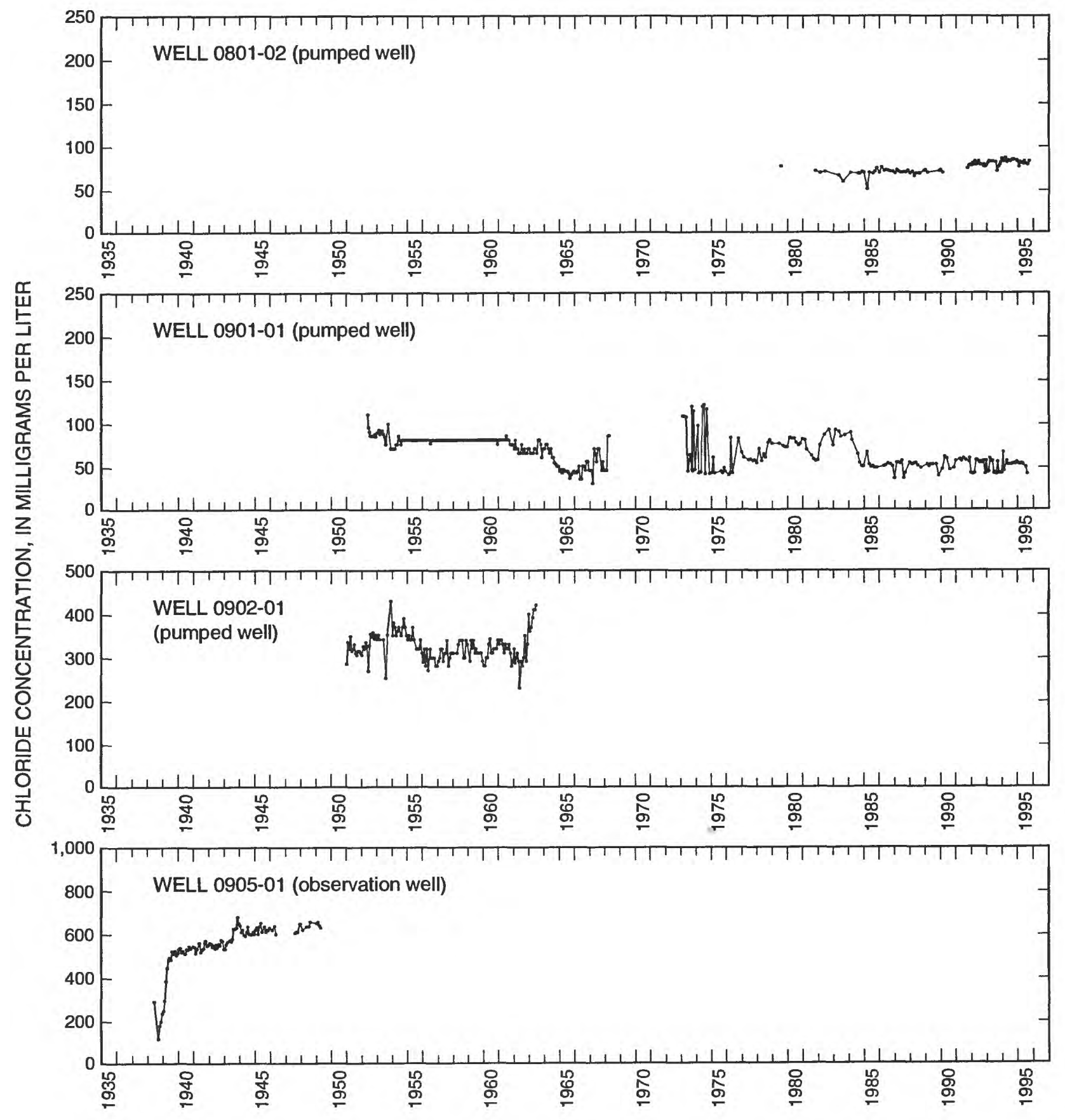

Figure 13. Chloride concentrations of ground water from selected wells, Molokai, Hawaii (data points not connected for data gaps exceeding one year)--Continued. 
abundance of dikes increases with depth, which reduces the overall permeability of the dike complex with depth. No data exist to evaluate the depth to which rocks are saturated with freshwater in the central part of the rift zone.

\section{Freshwater Lens}

Within the flank lava flows of the island, a lens of freshwater floats on denser, underlying saltwater. The source of freshwater in the lens is ground-water recharge from (1) upgradient high-level ground-water areas, (2) infiltration of rainfall, and (3) irrigation water. Fresh ground water flows from inland recharge areas to coastal discharge areas. A saltwater-circulation system exists beneath the lens (Souza and Voss, 1987). Saltwater flows landward in the deeper parts of the aquifer, rises, and then mixes with seaward-flowing freshwater. This mixing creates a freshwater-saltwater transition zone.

For hydrostatic conditions, the thickness of a freshwater lens can be estimated by the Ghyben-Herzberg principle. If the specific gravities of freshwater and saltwater are assumed to be 1.000 and 1.025 , respectively, then the Ghyben-Herzberg principle predicts that every foot of freshwater above sea level must be balanced by $40 \mathrm{ft}$ of freshwater below sea level. For dynamic conditions, the Ghyben-Herzberg principle tends to underestimate freshwater-lens thickness near the discharge zone and overestimate lens thickness near the recharge zone.

The thickness of a freshwater lens increases with (1) increasing rates of ground-water recharge, (2) decreasing rates of withdrawal, and (3) decreasing aquifer permeability. Where a coastal confining unit exists, water levels are higher and the thickness of a freshwater lens is expected to be greater than it would be in the absence of a confining unit.

\section{Regional Flow}

Regional ground-water flow directions drawn on the basis of water-level data, geophysical information, and topography, indicate that ground water flows from the mountainous interior areas to the coastal discharge areas (fig. 11). Ground water originating from eastern and western Molokai also flows toward the central Hoolehua Plain, from where it flows to either the northern or southern coast.
Ground-water discharges naturally from the aquifer at onshore springs and seeps in deeply incised valleys and subaerial and submarine coastal springs and seeps. In northeastern Molokai, springs typically occur where stream erosion has cut through dike compartments below the level of the water table. Ground-water discharge at these springs contributes to the baseflow of streams. Along the southern coast, fishponds have been created in shallow coastal waters by constructing rockwall enclosures extending from the shoreline. Because freshwater discharge to the ponds is necessary for growth of plants on which fish feed, the ponds may be evidence of the existence of springs (Stearns and Macdonald, 1947).

Ground water on Molokai is unconfined in the inland areas. Along the southern coast, ground water may be confined by sedimentary deposits that impede the seaward discharge of fresh ground water. A measured seismic velocity discontinuity at an altitude of about $-6,000 \mathrm{ft}$ measured in southwestern Oahu may coincide with a reduction in permeability of the volcanic rocks (Furumoto and others, 1970). Kauahikaua (1993) also suggests that a reduction in porosity on the island of Hawaii may occur near an altitude of $-6,000 \mathrm{ft}$. Although the base of the aquifer on Molokai is unknown, it may also extend down to an altitude near $-6,000 \mathrm{ft}$. Freshwater probably occurs in only the upper part of the aquifer, and in only a small fraction of the total thickness of the aquifer.

\section{DEVELOPMENT OF GROUND-WATER FLOW MODEL}

A two-dimensional, areal ground-water flow model using a modified version (see appendix A) of the computer code AQUIFEM-SALT (Voss, 1984) was developed to simulate steady-state ground-water flow on Molokai. AQUIFEM-SALT is a finite-element code that simulates flow of confined or unconfined fresh ground water in systems which may have a freshwater lens floating on denser underlying saltwater. AQUIFEM-SALT treats freshwater and saltwater as immiscible fluids separated by a sharp interface. The depth of the interface is determined by the GhybenHerzberg relation. In reality, a diffuse transition zone exists between the core of freshwater and the underlying saltwater. In this study, it is assumed that the position of the surface of 50-percent seawater salinity is 
approximated by the sharp interface position. AQUIFEM-SALT simulates the vertically averaged freshwater head in the aquifer and assumes that flow is entirely horizontal and all wells fully penetrate the freshwater lens.

\section{Model Construction}

A ground-water model for Molokai was developed to simulate ground-water levels and discharge for the period 1954-61. This period was selected for several reasons: (1) annual rainfall, ground-water withdrawal rates, and water levels do not vary significantly; (2) water-level data were available for the Kualapuu area, which represents the most important area for groundwater development; and (3) pineapple cultivation, which is the single largest human-induced stress on the ground-water flow system, existed during this period. The model accounts for spatially varying hydraulic characteristics of the geologic materials, recharge, and ground-water withdrawals.

The hydraulic characteristics were estimated from available data and were modified by varying them in the model to obtain acceptable agreement between measured and model-calculated water levels and baseflow discharges. However, the spatial coverage of long-term measured water levels is less than what is considered adequate to calibrate a numerical ground-water flow model. Long-term data were available at only six wells to define average water levels during the period 1954 61. The data set was supplemented by including data from all other wells in table 2 regardless of the period of measurement.

\section{Model Mesh}

The finite-element mesh used in this study consists of 6,432 nodes and 6,251 square elements, $1,640 \mathrm{ft}$ on a side, arranged in a rectangular array with 47 rows and 133 columns. The mesh is oriented with its short side in a north-south direction and has a geographic origin (upper left-hand, or northwest corner) at longitude $157^{\circ} 20^{\prime} 01^{\prime \prime} \mathrm{W}$ and latitude $21^{\circ} 14^{\prime} 39^{\prime \prime} \mathrm{N}$ (fig. 14). The mesh covers the entire island of Molokai and extends at least a mile offshore to include the entire zone where fresh ground water discharges to the ocean.

\section{Representation of the Physical System}

For modeling purposes, the island of Molokai was divided into seven horizontal-hydraulic-conductivity zones (fig. 14): (1) dike-free West Molokai Volcanics (flank-flow volcanic rocks), (2) dike-free East Molokai Volcanics (flank-flow volcanic rocks), (3) Kalaupapa Volcanics, (4) West Molokai Volcanics confining unit, (5) West Molokai Volcanics dike complex, (6) East Molokai Volcanics dike complex exclusive of the marginal dike zone, and (7) East Molokai Volcanics marginal dike zone. The first three zones represent the dikefree, flank-flow volcanic rocks. The West Molokai confining-unit zone represents the zone, formed by weathered volcanic rocks and soil, between West and East Molokai Volcanics. Although the confining unit dips at an angle of only $10^{\circ}$ it extends throughout the freshwater-lens thickness and likely impedes ground-water flow between the West and East Molokai Volcanics. In this study, the West Molokai confining unit is represented in the two-dimensional model as a barrier to horizontal flow with a zone of reduced hydraulic conductivity. The West and East Molokai dike-complex zones are modeled as zones of lower overall hydraulic conductivity relative to the dike-free volcanic-aquifer zones. A model zone was created for the assumed East Molokai marginal dike zone, where numerous volcanicvent features exist. The hydraulic conductivity of the East Molokai marginal dike zone is presumed to lie between the values for the dike-free volcanic rocks and the East Molokai dike complex. The bottom of the model was assigned an altitude of $-6,000 \mathrm{ft}$, relative to a zero datum of mean sea level, to coincide with an assumed aquifer bottom.

\section{Boundary Conditions}

AQUIFEM-SALT supports three types of boundary conditions: (1) specified head, (2) specified flow (which includes no flow), and (3) head-dependent discharge. Specified-head boundary conditions were not used for this study. The perimeter of the mesh is a noflow boundary.

Freshwater discharges at the coast and at springs in northeastern Molokai valleys were modeled using a head-dependent discharge boundary condition. Six discharge zones were defined (fig. 15): (1) southeastern Molokai coast, (2) southwestern Molokai coast, (3) northern Molokai coast exclusive of Kalaupapa Peninsula, (4) Kalaupapa Peninsula, (5) northeastern Molokai streams in the dike complex within the caldera area, and (6) northeastern Molokai streams in the dike complex outside the caldera area. 


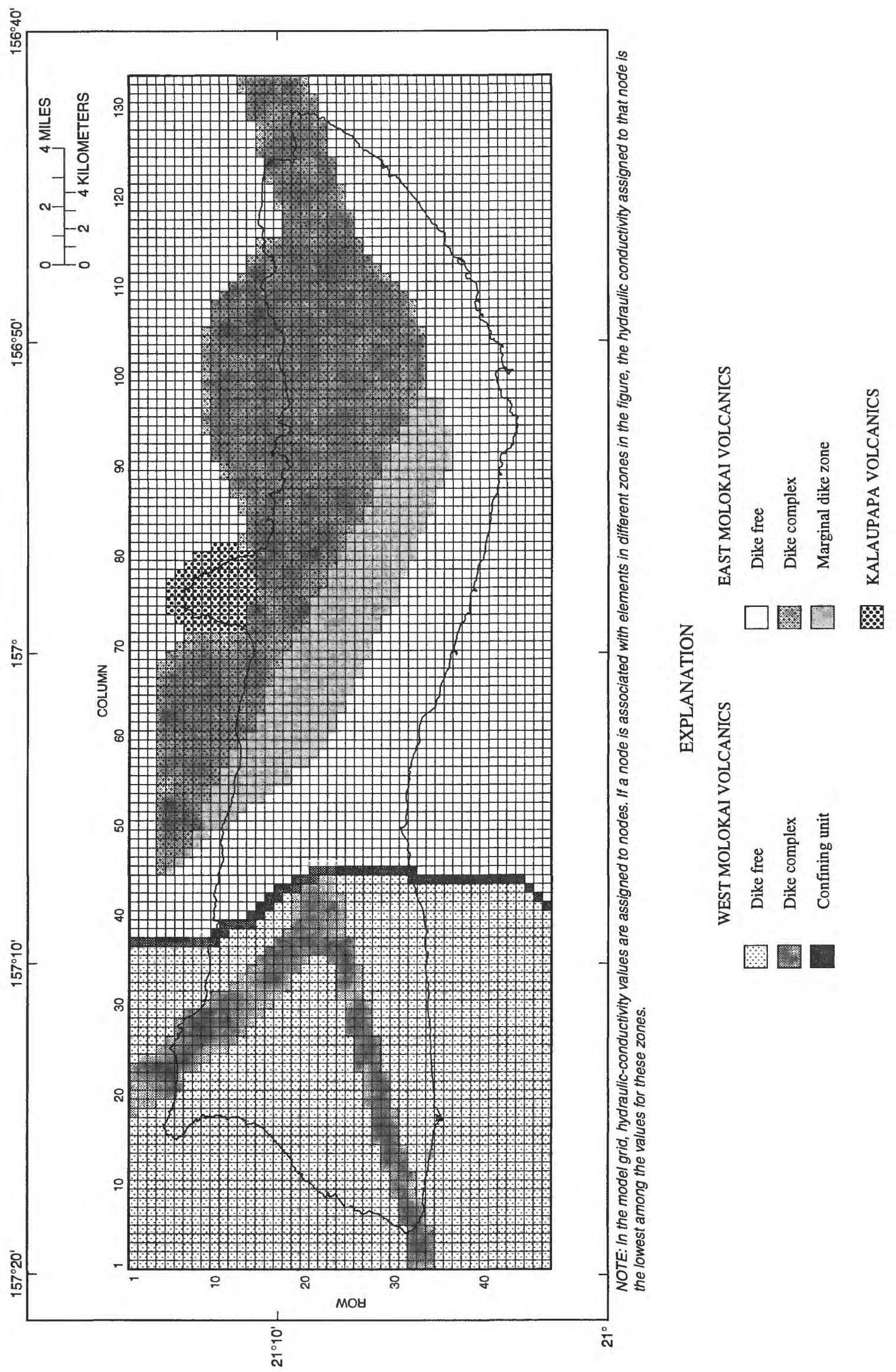

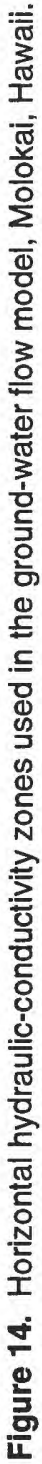




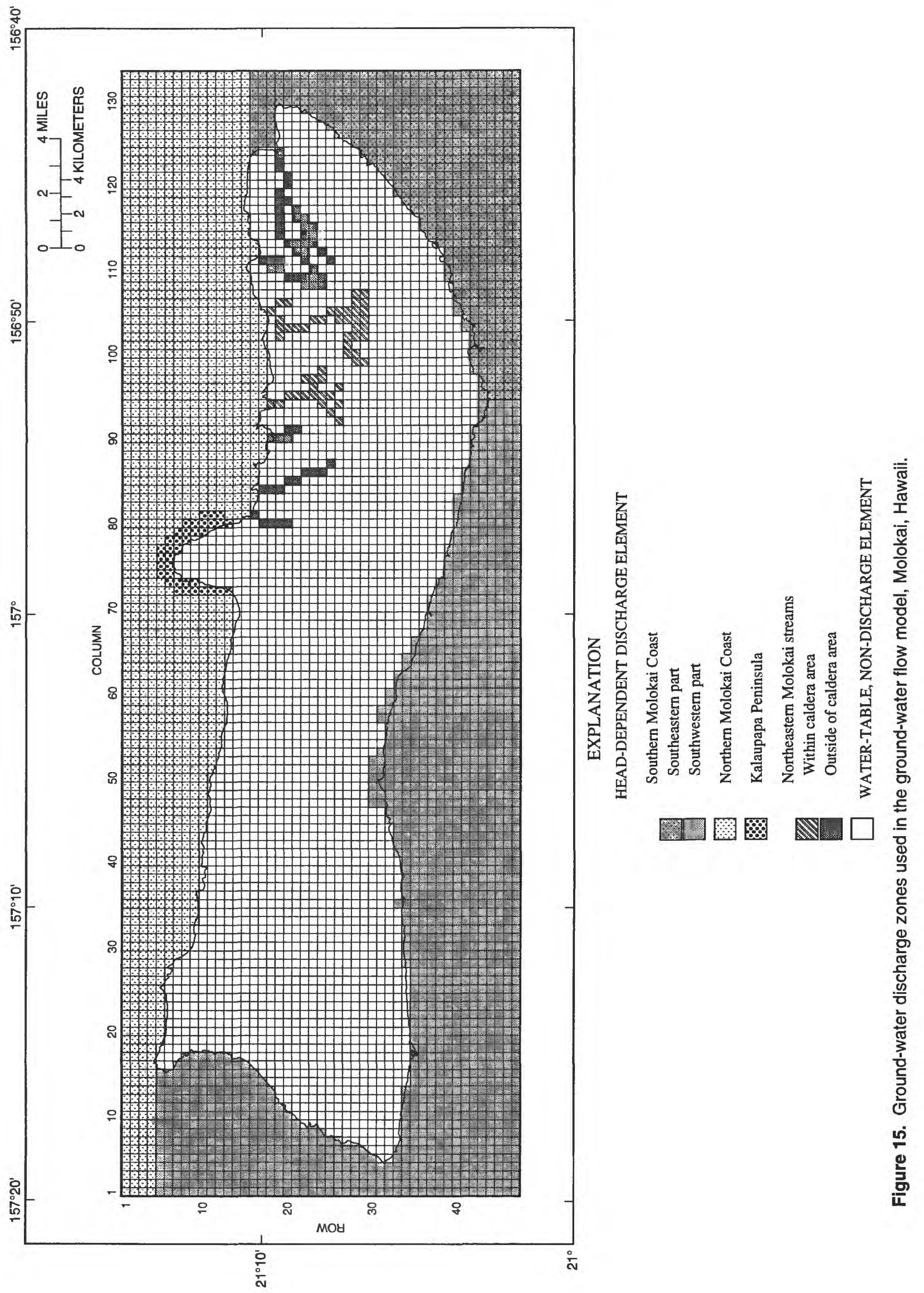


In the model, all elements not simulated as a headdependent discharge boundary are water-table elements. Head-dependent discharge elements associated with streams are simulated as confined elements if the model-calculated head is above the base of the stream, and as water-table elements otherwise. The base of the stream within an element was estimated from the average stream-channel altitude (U.S. Geological Survey, 1952) within that element.

Flow out of the model at head-dependent discharge elements is assumed to be linearly related to the difference between the head in the aquifer and the head overlying the confining unit at the discharge site according to the equation:

$$
Q=\left(K^{\prime} / B^{\prime}\right) A\left(h-h_{0}\right),
$$

where:

$Q$ is the rate of discharge within a model element $\left[\mathrm{L}^{3} / \mathrm{T}\right]$,

$K^{\prime}$ is the vertical hydraulic conductivity of the confining unit overlying the aquifer $[\mathrm{L} / \mathrm{T}]$,

$B^{\prime}$ is the thickness of the confining unit overlying the aquifer [L],

$A$ is the area of the model element $\left[\mathrm{L}^{2}\right]$,

$h$ is the head in the aquifer [L], and

$h_{0}$ is the head above the confining unit [L].

The confining-unit vertical hydraulic conductivity divided by the confining-unit thickness forms a lumped parameter known as the leakance. For eastern, southern, and western Molokai, the confining-unit thickness was estimated by noting the difference in altitude between the bathymetry (fig. 16) and offshore-projected surfaces of the West and East Molokai Volcanoes. The thickness of the southern Molokai coastal deposits is estimated to vary from about 10 to $500 \mathrm{ft}$ (fig. 17) on the basis of the method described in the subsection "Coastal Deposits." Because of the Wailau debris avalanche, no attempt was made to estimate separate values for confining-unit thickness and vertical hydraulic conductivity for northern Molokai; instead, the lumped parameter, leakance, was estimated by trial and error. For the stream elements, leakance was also estimated by trial and error.

The head, $h_{0}$, overlying the confining unit above onshore coastal-discharge elements is unknown but is probably near mean sea level, and is assumed to be zero. For offshore elements, $h_{0}$ was assigned a value corresponding to the freshwater equivalent head of the saltwater column overlying the ocean floor within the element (see appendix A). For these offshore elements, the freshwater equivalent head was computed from the equation:

$$
h_{0}=-Z / 40
$$

where $Z$ is the altitude of the ocean floor (fig. 16).

For elements representing the springs in northeastern Molokai valleys, $h_{0}$ was assigned a value corresponding to the average altitude (U.S. Geological Survey, 1952) of the stream channel within the model element. Ground-water discharge was modeled at elements representing Waialeia, Waikolu, Waiohookalo, Kawainui, and Halawa Streams in the dike complex outside of the caldera area, and at model elements representing Pelekunu, Wailau, and Kahawaiiki Streams in the caldera area.

\section{Ground-Water Withdrawals}

On the basis of available information, groundwater withdrawals on Molokai during 1954-61 averaged $0.731 \mathrm{Mgal} / \mathrm{d}$ (table 3) from five wells. All of the reported withdrawals are from wells either in the Kualapuu area or near the southern coast. Unreported withdrawals from wells not in table 3 are probably small and are not represented in the model.

\section{Recharge}

Average annual recharge for 1954-61 was 201.3 $\mathrm{Mgal} / \mathrm{d}$. The areal distribution of recharge used in the model is shown in figure 18. Total recharge used in the model was $200.0 \mathrm{Mgal} / \mathrm{d}$ because discretization at the coastline results in land area receiving $1.3 \mathrm{Mgal} / \mathrm{d}$ recharge being assigned to offshore elements. This loss in recharge is less than 1 percent of the total value, and is well within the range of uncertainty associated with the recharge estimates.

\section{Estimation of Hydraulic Characteristics}

The sequence of steps used to estimate the hydraulic characteristics (table 4) are described below.

1. The horizontal hydraulic conductivity for the West Molokai confining-unit zone was assigned a value of $1 \mathrm{ft} / \mathrm{d}$ and was not changed in subsequent steps.

2. The horizontal hydraulic conductivity for the Kalaupapa Volcanics zone and leakance for the Kalaupapa Peninsula were adjusted in a trial-and-error 
Table 3. Pumping rates used in the ground-water flow model, Molokai, Hawaii

\begin{tabular}{|c|c|c|c|}
\hline \multirow{2}{*}{$\begin{array}{l}\text { Well no. } \\
\text { or tunnel }\end{array}$} & \multirow[b]{2}{*}{ Model node no.' } & \multicolumn{2}{|c|}{$\begin{array}{c}\text { Average pumping rate } \\
\text { (million galions per day) }\end{array}$} \\
\hline & & $1954-61$ & $1992-96$ \\
\hline $0356-01$ & 3976 & 0.000 & 0.0005 \\
\hline 0449-01 & 5032 & 0.077 & 0.185 \\
\hline $0456-04$ & 3880 & 0.000 & 0.013 \\
\hline $0456-06$ & 3879 & 0.000 & 0.081 \\
\hline 0456-08 & 3927 & 0.000 & 0.061 \\
\hline $0456-09$ & 3975 & 0.000 & 0.026 \\
\hline $0457-01$ & 3831 & 0.233 & 0.370 \\
\hline $0457-04$ & 3734 & 0.000 & 0.053 \\
\hline 0501-04 & 3202 & 0.000 & 0.072 \\
\hline 0501-06 & 3203 & 0.000 & 0.004 \\
\hline 0601-01 & 3153 & 0.000 & 0.088 \\
\hline 0603-01 & 2767 & 0.000 & 0.065 \\
\hline $0705-05$ & 2474 & 0.000 & 0.012 \\
\hline 0801-01 & 3142 & 0.029 & 0.089 \\
\hline 0801-02 & 3142 & 0.000 & 0.447 \\
\hline 0801-03 & 3142 & 0.000 & 0.553 \\
\hline 0855-01 & 4104 & 0.000 & 0.304 \\
\hline 0855-02 & 4103 & 0.000 & 0.308 \\
\hline 0855-03 & 4151 & 0.000 & 0.436 \\
\hline 0901-01 & 3094 & 0.350 & 1.174 \\
\hline $0902-01$ & 2948 & 0.042 & 0.000 \\
\hline $1058-01$ & 3664 & 0.000 & 0.061 \\
\hline Molokai Irrigation System Tunnel & 4008 & 0.000 & 0.911 \\
\hline Molokai Irrigation System Tunnel & 4056 & 0.000 & 0.911 \\
\hline 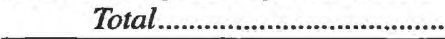 & ............. &. .0 .731 & 6.225 \\
\hline
\end{tabular}

${ }^{1}$ Finite element node number and element number can be determined from the row and column number of the cell:

Node number (upper left or northwest corner of cell) $=$ row $+48 \times($ column -1$)$

Node number (lower left or southwest corner of cell) $=$ row $+48 \times($ column -1$)+1$

Node number (upper right or northeast corner of cell) $=$ row $+48 \times$ (column)

Node number (lower right or southeast corner of cell $)=$ row $+48 \times($ column $)+1$

Element number $=$ row $+47 \times($ column -1$)$

Table 4. Final parameter values used in the Molokai ground-water flow model, Hawaii

\begin{tabular}{lc}
\hline Model zone & $\begin{array}{c}\text { Hydraulic conductivity } \\
\text { (feet per day) }\end{array}$ \\
West Molokai dike-free aquifer & 1,000 \\
West Molokai dike complex & 2 \\
West Molokai confining unit & 1 \\
East Molokai dike-free aquifer & 1,000 \\
East Molokai marginal dike zone & 100 \\
East Molokai dike complex & 0.02 \\
Kalaupapa Volcanics & 500 \\
Coastal discharge zone & \\
Northern Molokai & leakance $=0.1$ per day \\
Kalaupapa & 0.5 \\
Southern Molokai, east of Kamalo & 5 \\
Southern Molokai, west of Kamalo & \\
Stream discharge zone & \\
Waialeia, Waikolu, Papalaua, Halawa & \\
Waiohookalo, Pelekunu, Wailau, Kahawaiiki & leakance $=1.2 \times 10^{-3}$ per day \\
leakance $=6.1 \times 10^{-5}$ per day
\end{tabular}




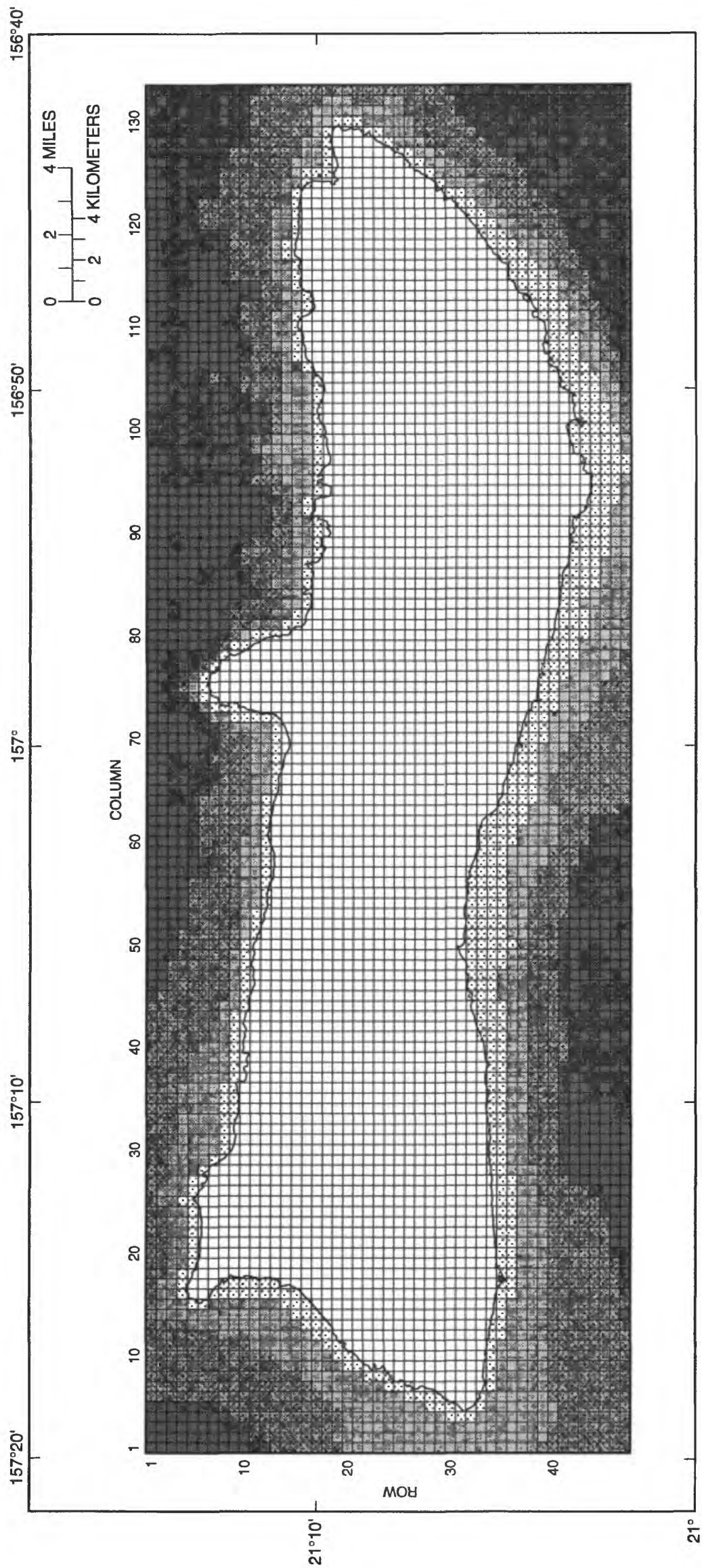

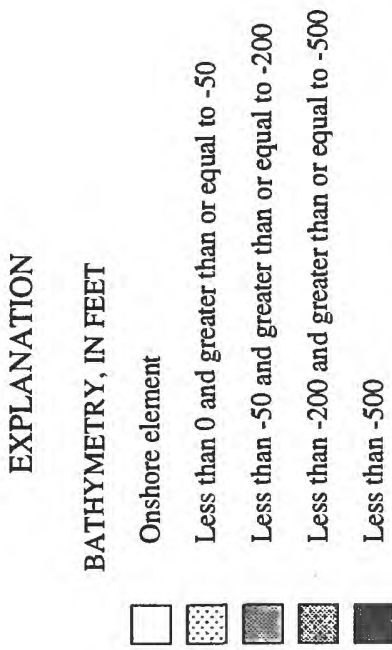

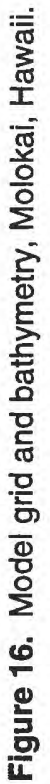



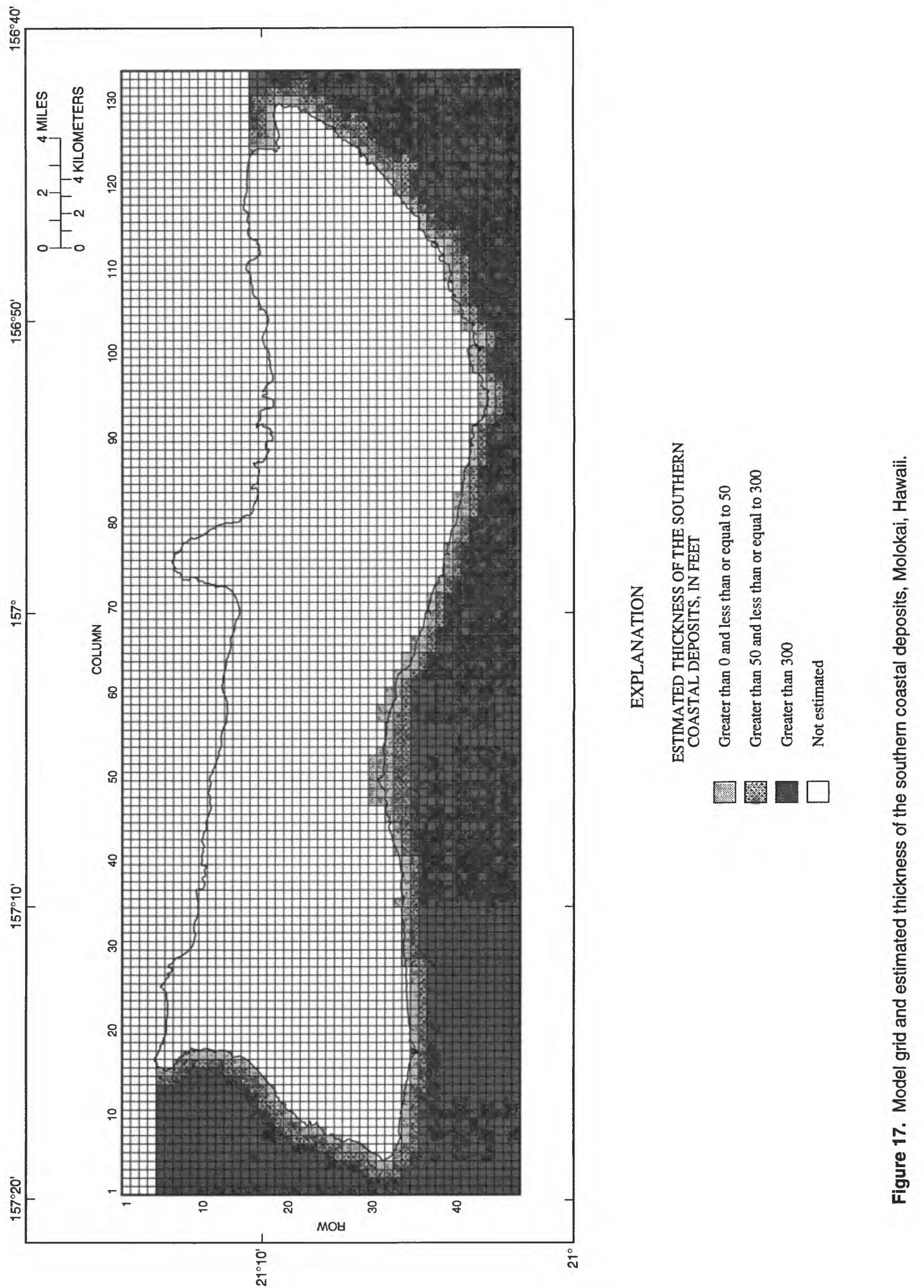


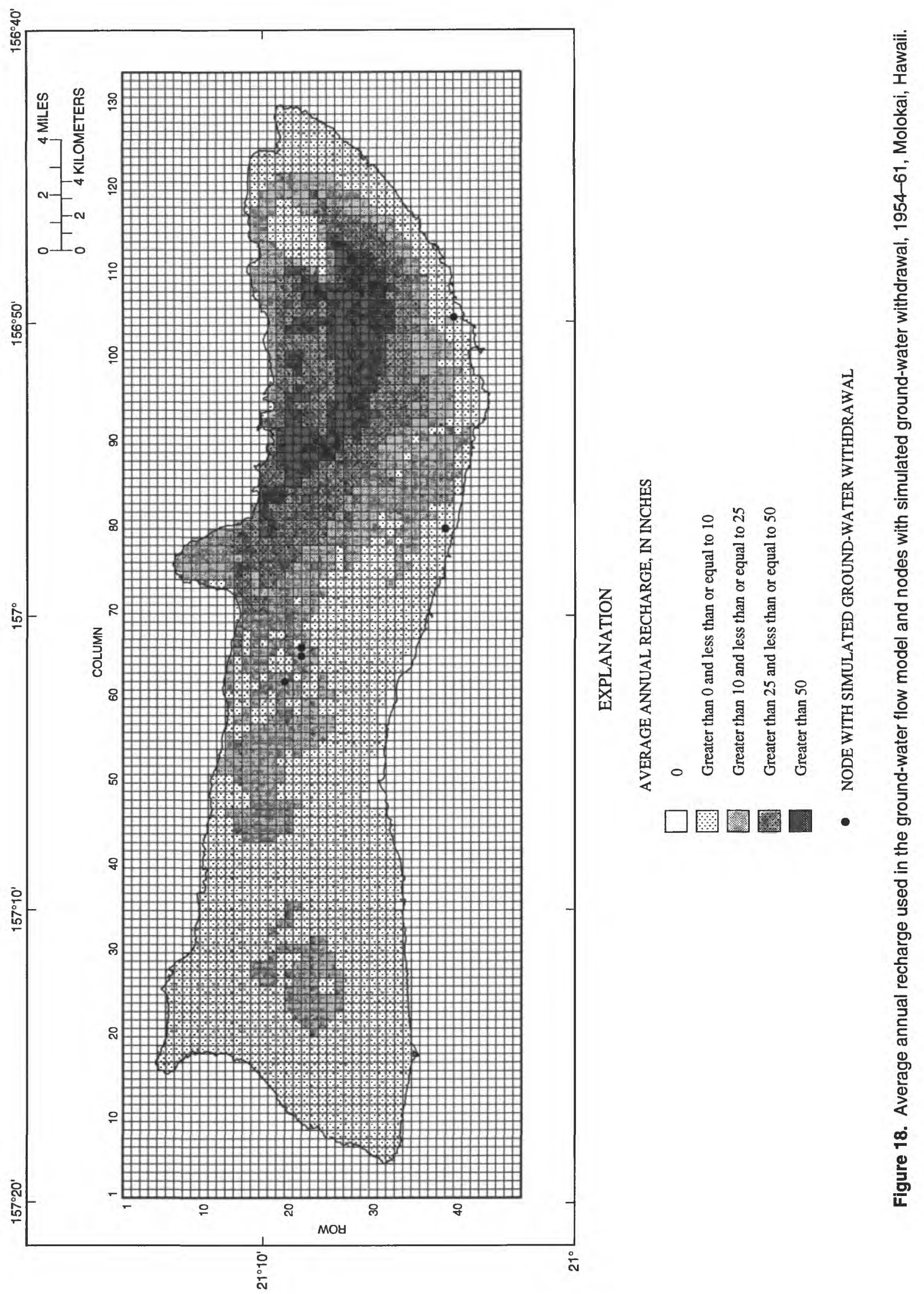


procedure to obtain a freshwater lens with a head of a few feet above sea level in the Kalaupapa Volcanics zone. The values of horizontal hydraulic conductivity and leakance obtained by this procedure were $500 \mathrm{ft} / \mathrm{d}$ and 0.1 per day, respectively. These values were not changed in subsequent steps.

3. The horizontal hydraulic conductivity for the West Molokai dike complex was estimated by trial and error to obtain a maximum model-calculated head of about $15 \mathrm{ft}$ near the summit, to be consistent with the results of MacCarthy's (1941) resistivity survey (fig. 11). The value obtained was $2 \mathrm{ft} / \mathrm{d}$ and was not changed in subsequent steps.

4. The horizontal hydraulic conductivity for the East Molokai dike complex and streambed leakances for the northeastern Molokai streams within and outside of the caldera area were adjusted by trial and error to obtain: (1) model-calculated water levels of about $1,000 \mathrm{ft}$ above mean sea level in the vicinity of wells $0855-01$ to -03 ; (2) maximum model-calculated water levels up to $2,000 \mathrm{ft}$ and possibly higher (Stearns and Macdonald, 1947, p. 75) where springs exist; and (3) model-calculated discharge to streams in agreement with estimated baseflow (table 1). The horizontal hydraulic conductivity for the East Molokai dike complex was estimated to be $0.02 \mathrm{ft} / \mathrm{d}$ and was not changed. The estimated hydraulic-conductivity value for the East Molokai dike complex is lower than the estimated value for the West Molokai dike complex, which may be attributed to a greater number of low-permeability dikes needed to build the higher East Molokai Volcano. The leakance for streams within and outside of the caldera area were estimated to be $6.1 \times 10^{-5}$ per day and $1.2 \times 10^{-3}$ per day, respectively, and were not changed.

5. A set of 64 simulations was made to determine the effects on water levels of the remaining hydraulic characteristics not finalized up to this step. In this set, zones were combined in an attempt to produce a parsimonious representation of the system. All possible combinations of four values of each of three different hydraulic characteristics $(4 \times 4 \times 4$ $=64$ ) were used: (1) values of $250 ; 500 ; 1,000$; and $2,000 \mathrm{ft} / \mathrm{d}$ for the horizontal hydraulic conductivity in a combined area consisting of three zones (dike- free West and East Molokai Volcanics, and East Molokai marginal dike zone); (2) values of 0.05 , $0.5,1.0$ and $5.0 \mathrm{ft} / \mathrm{d}$ for the vertical hydraulic conductivity in a combined area consisting of the southeastern and southwestern coastal discharge zones; and (3) values of $0.0001,0.001,0.01$, and 0.1 per day for the leakance of the northern coastal discharge zone. Results of these simulations (appendix B) indicate that a parsimonious model is not capable of producing model-calculated water levels in agreement with measured water levels in all areas. However, information from these simulations narrowed the ranges of hydraulic characteristics for the various zones and was used in the next and last step.

6. A trial-and-error procedure was used to estimate the final values of five hydraulic characteristics: (1) a horizontal hydraulic conductivity of $1,000 \mathrm{ft} / \mathrm{d}$ in the West and East Molokai Volcanics dike-free zones [note that these two zones were combined because data were insufficient to estimate independent values for each zone], (2) a horizontal hydraulic conductivity of $100 \mathrm{ft} / \mathrm{d}$ in the East Molokai marginal dike zone, (3) a vertical hydraulic conductivity of $0.5 \mathrm{ft} / \mathrm{d}$ in the southeastern coastal-discharge zone, (4) a vertical hydraulic conductivity of $5 \mathrm{ft} / \mathrm{d}$ in the southwestern coastal-discharge zone, and (5) a leakance of 0.1 per day in the northern coastal-discharge zone.

\section{Model-Calculated Water Levels}

The model-calculated water levels are in general agreement with the limited set of measured water levels (figs. 19 and 20). Considering the five wells with acceptable long-term water-level records (fig. 12) (well 0449-01 must be resurveyed and was therefore excluded), the average, average-absolute, and rootmean-square of the differences between measured and model-calculated water levels were $-0.077,0.953$, and $0.965 \mathrm{ft}$, respectively. Considering water-level data from all available wells, with the exception of those in the East Molokai dike complex and well 0449-01, the average, average-absolute, and root-mean-square of the differences were $-0.201,1.348$, and $1.838 \mathrm{ft}$, respectively. 


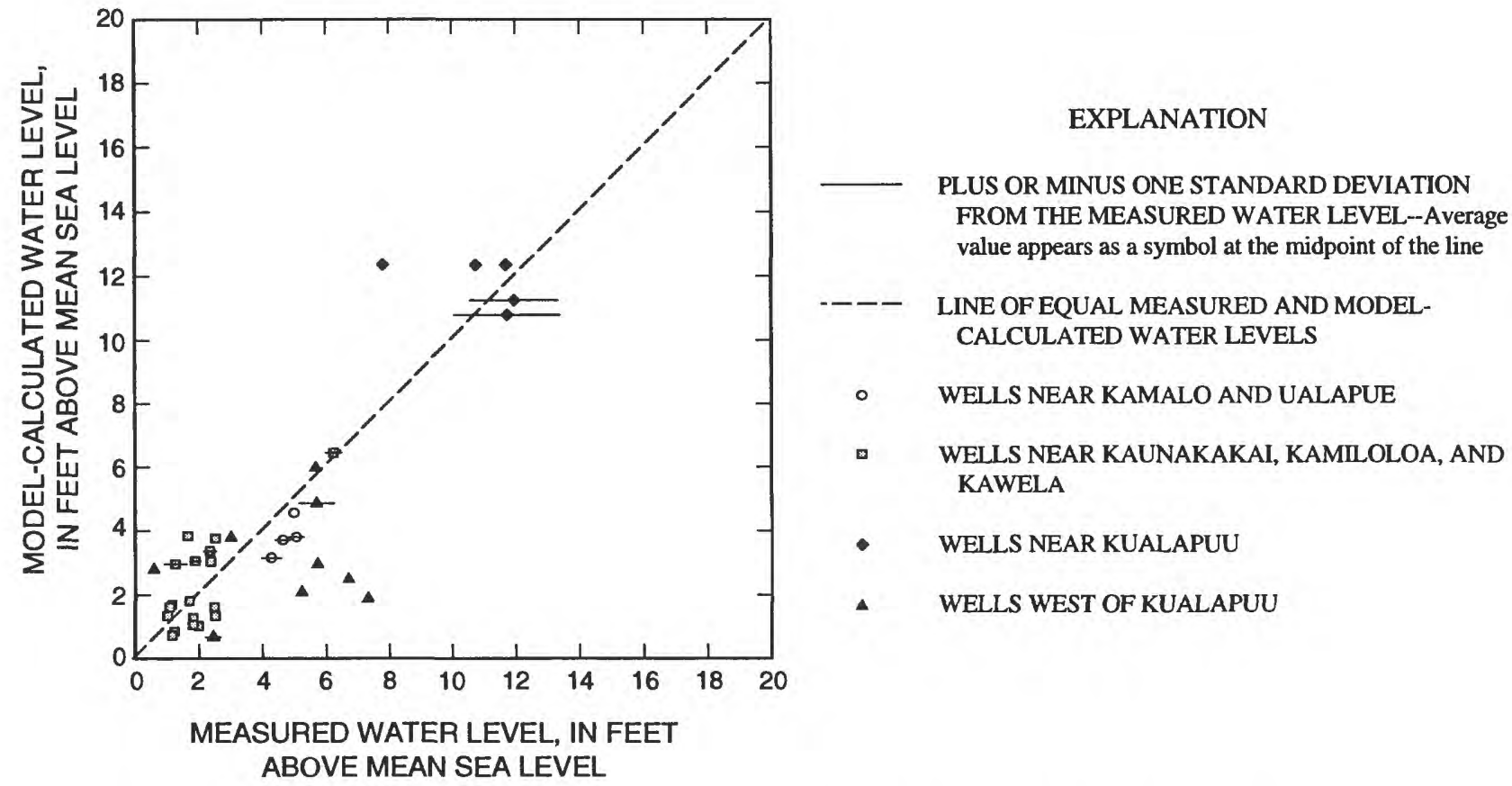

Figure 19. Final model-calculated and measured water levels, 1954-61, Molokai, Hawaii.

\section{Model-Calculated Ground-Water Discharge}

About 54 percent of the total model-calculated ground-water discharge is coastal discharge along eastern, southern, and western Molokai, 17 percent is coastal discharge along northern Molokai, 29 percent is discharge to streams in northeastern valleys, and the remainder $(0.35$ percent) is ground-water withdrawal from wells (table 5).

Model-calculated ground-water discharge to streams is in general agreement with estimated baseflow at the gaging stations except at Halawa Stream (table 1). Although there is baseflow in Halawa Stream, the model-calculated discharge to Halawa Stream is zero because the model-calculated heads near the stream are below the stream bed. The cause of this discrepancy is unknown but two can be suggested: (1) the baseflow in the stream may be from an upstream marsh (fig. 10) rather than ground-water discharge (Stearns and Macdonald, 1947, p. 47), and (2) there may be local low values of hydraulic conductivity and corresponding local high water levels, which are not represented in the regional model.

\section{EFFECTS OF PROPOSED WITHDRAWALS}

The final hydraulic characteristics (table 4) described in the previous section were used in the model to simulate water levels and discharges for a 1990's base-case scenario. This base case was used as a reference for computing water-level drawdown and changes in ground-water discharges from three different proposed withdrawal scenarios. In the three scenarios, the model-calculated decrease in depth to the freshwatersaltwater interface is 40 times the model-calculated drawdown.

\section{Simulation of Average Conditions in the 1990's}

Long-term average recharge for natural vegetation conditions, estimated to be $188.6 \mathrm{Mgal} / \mathrm{d}$ (Shade, in press), and average 1992-96 ground-water withdrawal rates were used in the base-case scenario. In the model, total recharge used was $187.3 \mathrm{Mgal} / \mathrm{d}$ because discretization at the coastline results in land area receiving 1.3 $\mathrm{Mgal} / \mathrm{d}$ recharge being assigned to offshore elements (fig. 21). Average reported withdrawal rates from wells 


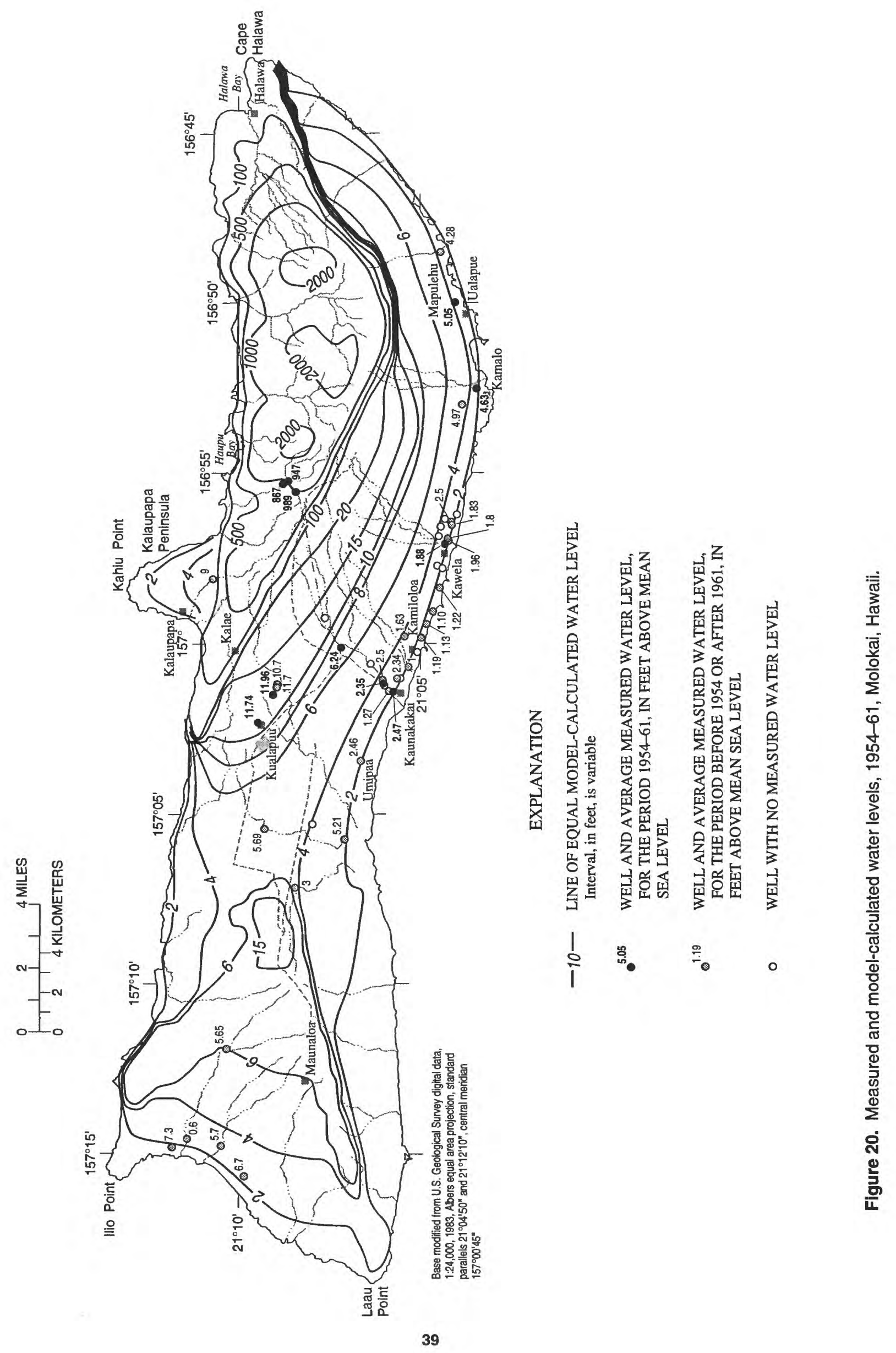




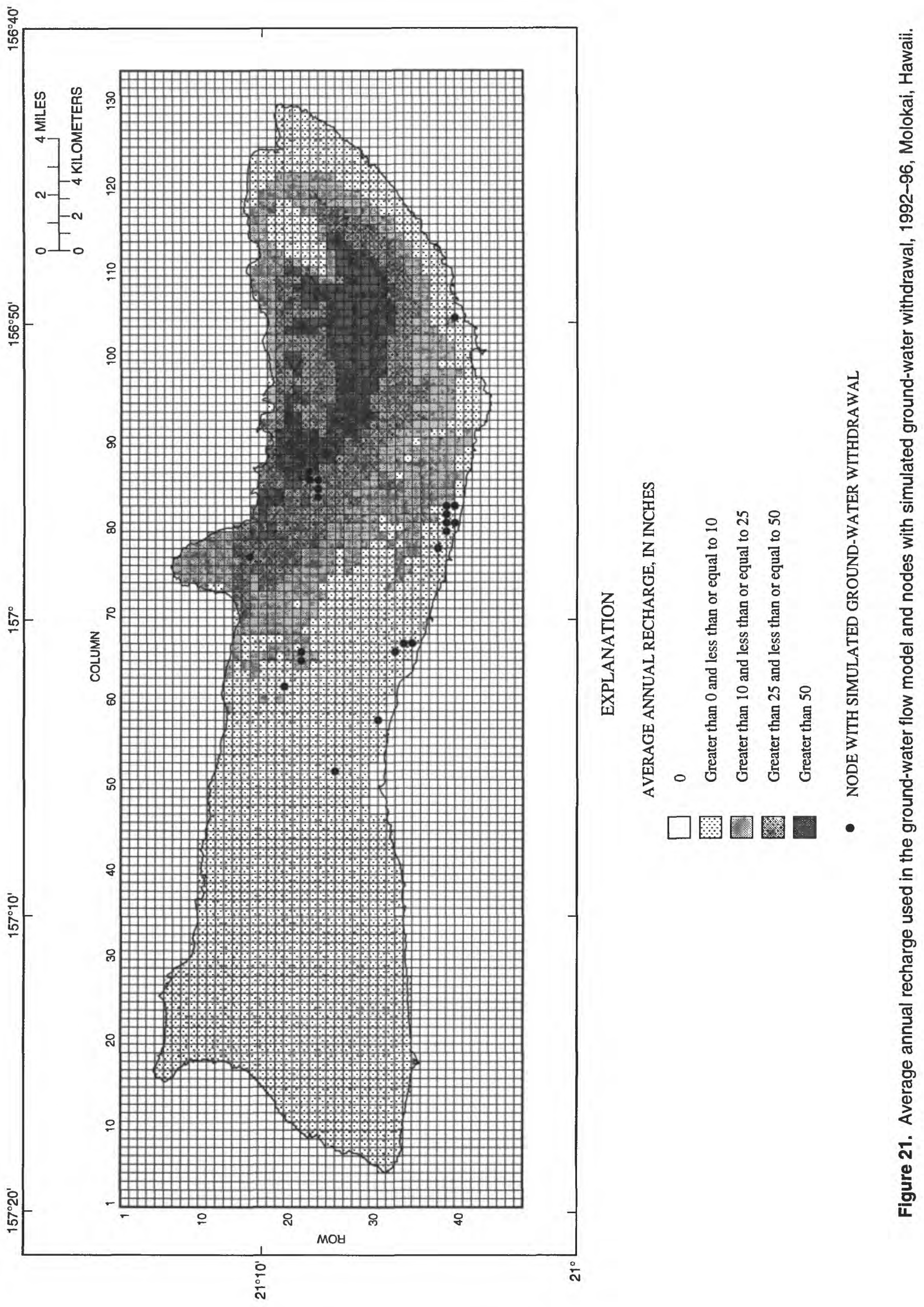


during the period 1992-96 (table 3) were computed from data provided by CWRM (Neal Fujii, written commun., 1997). Average reported total pumpage from wells during the period 1992-96 was $4.403 \mathrm{Mgal} / \mathrm{d}$. Additional ground-water withdrawal from the Molokai Irrigation System tunnel of about $1.822 \mathrm{Mgal} / \mathrm{d}$ was also represented as pumping at two model nodes.

Model-calculated water levels for average 199296 withdrawal rates (fig. 22) are lower than the modelcalculated water levels from the 1954-61 simulation period (fig. 20): water levels are lower by about $0.1 \mathrm{ft}$ along the southern coast, and 1 to $5 \mathrm{ft}$ near Kualapuu and the central part of West Molokai. In eastern Molokai, water levels from the two simulations differ by less than $0.01 \mathrm{ft}$. The general decrease in water levels can be attributed to a reduction of recharge associated with cessation of pineapple cultivation, and an increase in ground-water withdrawals. For the period 1954-61, recharge and ground-water withdrawal rates used in the model were 200.0 and $0.731 \mathrm{Mgal} / \mathrm{d}$, respectively. For the 1990's base-case scenario, recharge and groundwater withdrawal rates used in the model were 187.3 and $6.225 \mathrm{Mgal} / \mathrm{d}$, respectively, which represents a net loss of ground-water discharge of about $18 \mathrm{Mgal} / \mathrm{d}$ relative to the period 1954-61.

Model-calculated flow directions for the 1990's base-case scenario indicate that ground water generally flows from the mountainous, interior recharge areas to coastal-discharge areas (fig. 23). Ground water flowing eastward from the West Molokai Volcano converges with westward-flowing water from the East Molokai Volcano in the central Hoolehua Plain area, where a ground-water divide separates flow to the northern and southern coasts (fig. 23). The model-calculated groundwater divide separating flow to the northern and southern coasts lies to either the north or the south of the topographic divide but is generally not coincident with the topographic divide.

Total model-calculated ground-water discharge from the system for the 1990 's base case is 187.3 $\mathrm{Mgal} / \mathrm{d}$ (table 5). Of this discharge, 51 percent is coastal discharge along eastern, southern, and western Molokai, 16 percent is coastal discharge along northern Molokai, 30 percent is discharge to streams in northeastern valleys, and the remaining 3 percent is groundwater withdrawal from wells and the Molokai Irrigation System tunnel.
Table 5. Recharge used in the model and distribution of model-calculated ground-water discharge, Molokai, Hawaii

\begin{tabular}{lrr}
\hline & $1954-61$ & $1992-96$ \\
\hline Recharge, in million gallons per day & 200.0 & 187.3 \\
& & \\
Discharge, in million gallons per day & & \\
Pumpage & 0.7 & 6.2 \\
High-level spring discharge & 57.5 & 55.5 \\
Coastal discharge, northern Molokai & 34.4 & 30.4 \\
Coastal discharge, southern Molokai & 107.3 & 95.2 \\
Total discharge & 199.9 & 187.3 \\
\hline
\end{tabular}

\section{Simulation of the Hydrologic Effects of Additional Withdrawals}

The ground-water flow model developed for this study is the best available tool for qualitatively demonstrating the hydrologic effects of additional withdrawals on ground-water levels and coastal discharge on Molokai. To estimate the hydrologic effects, relative to the 1990's base-case scenario, three additional scenarios were simulated. In scenarios 1 and 2, withdrawal rates of 0.377 and $1.326 \mathrm{Mgal} / \mathrm{d}$, respectively, were simulated from a proposed well located about $4 \mathrm{mi}$ southeast of Kualapuu and 3 mi north of Kamiloloa. In scenario 3, the 1992-96 average withdrawal rate of $0.826 \mathrm{Mgal} / \mathrm{d}$ at well 0901-01 near Kualapuu was increased by 1.174 $\mathrm{Mgal} / \mathrm{d}$ to $2.000 \mathrm{Mgal} / \mathrm{d}$. The wells with additional withdrawals were sited in areas where model-calculated water levels were in general agreement with measured water levels. Wells with additional withdrawals were not sited in areas lacking measured water levels because of the uncertainty in model results in these areas.

\section{Scenarios 1 and 2-Additional Withdrawal from the Kamiloloa Area}

In scenarios 1 and 2 , the proposed well was pumped at rates of 0.337 and $1.326 \mathrm{Mgal} / \mathrm{d}$, respectively, which corresponds to the range of anticipated demand. For a withdrawal rate of $0.337 \mathrm{Mgal} / \mathrm{d}$, the model-calculated drawdown of $0.01 \mathrm{ft}$ or more extends $4 \mathrm{mi}$ southeast and $6 \mathrm{mi}$ northwest from the well (fig. 24). In the vicinity of wells in the Kualapuu area, model-calculated drawdown is less than $0.1 \mathrm{ft}$. For a withdrawal rate of $1.326 \mathrm{Mgal} / \mathrm{d}$, the model-calculated drawdown of $0.01 \mathrm{ft}$ or more extends $6 \mathrm{mi}$ southeast and $9 \mathrm{mi}$ northwest from the well (fig. 25). Model-calculated ground-water levels will be lowered by more than $0.1 \mathrm{ft}$ over an area extending from 2 to $4 \mathrm{mi}$ from the site 


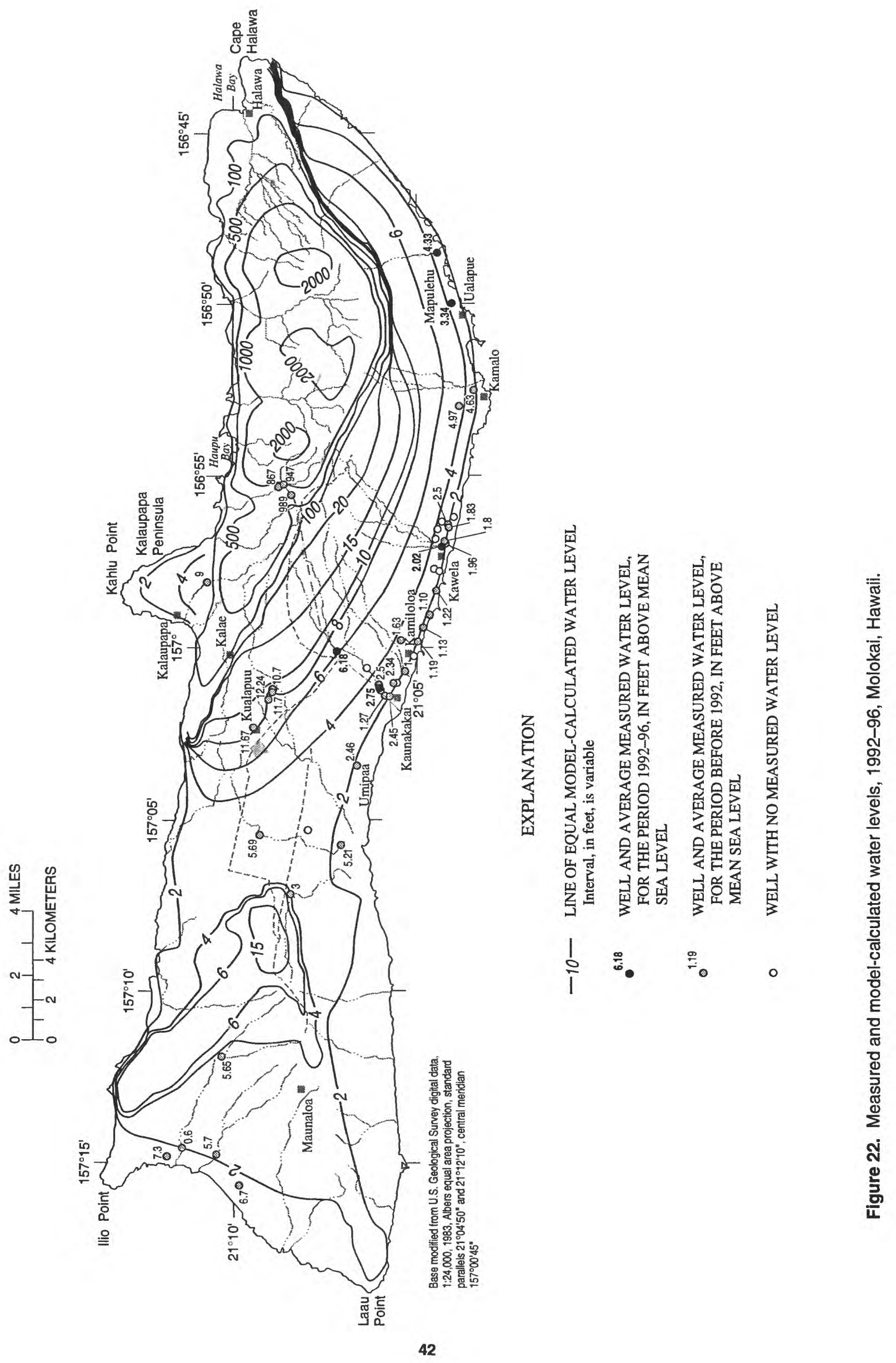




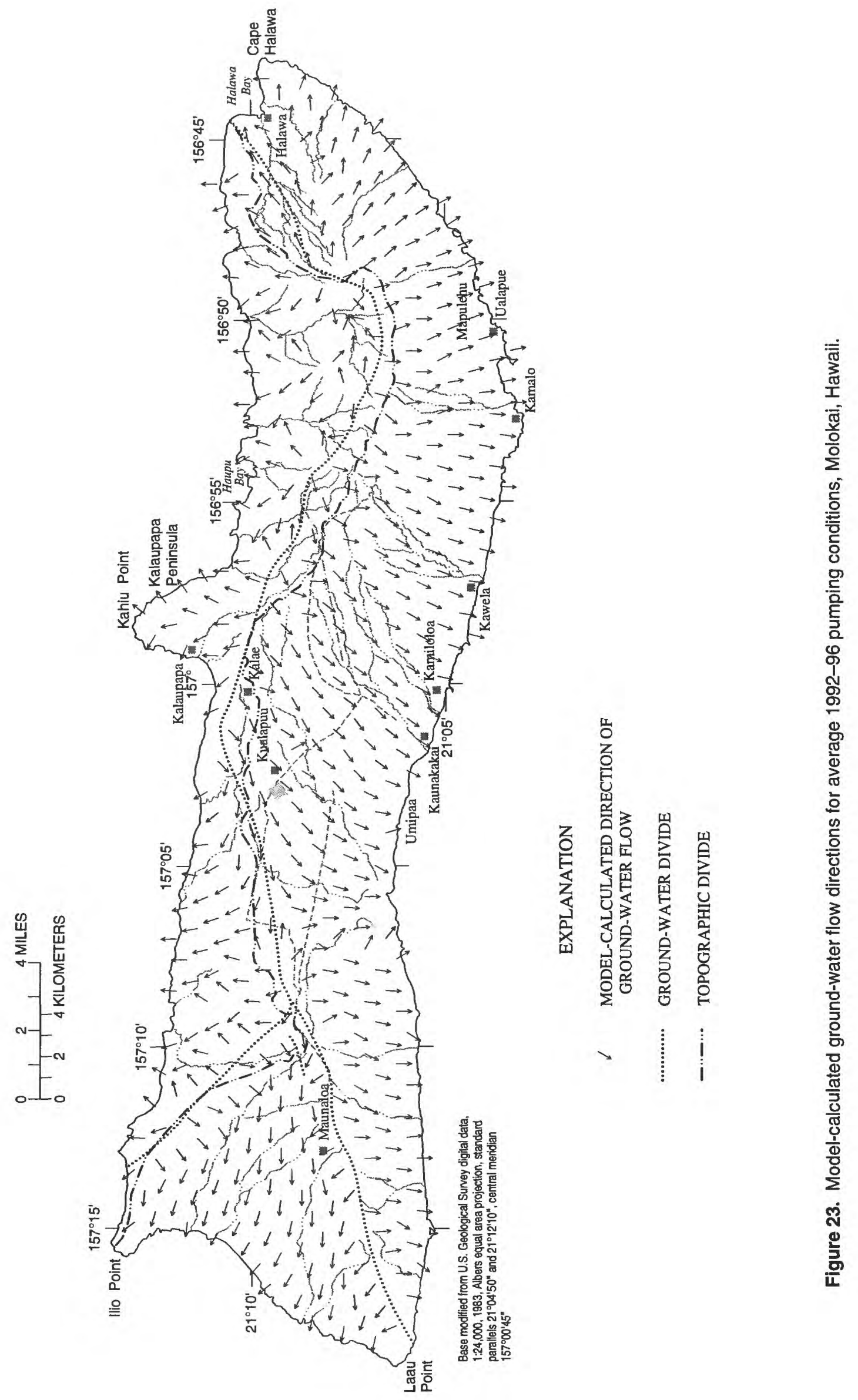




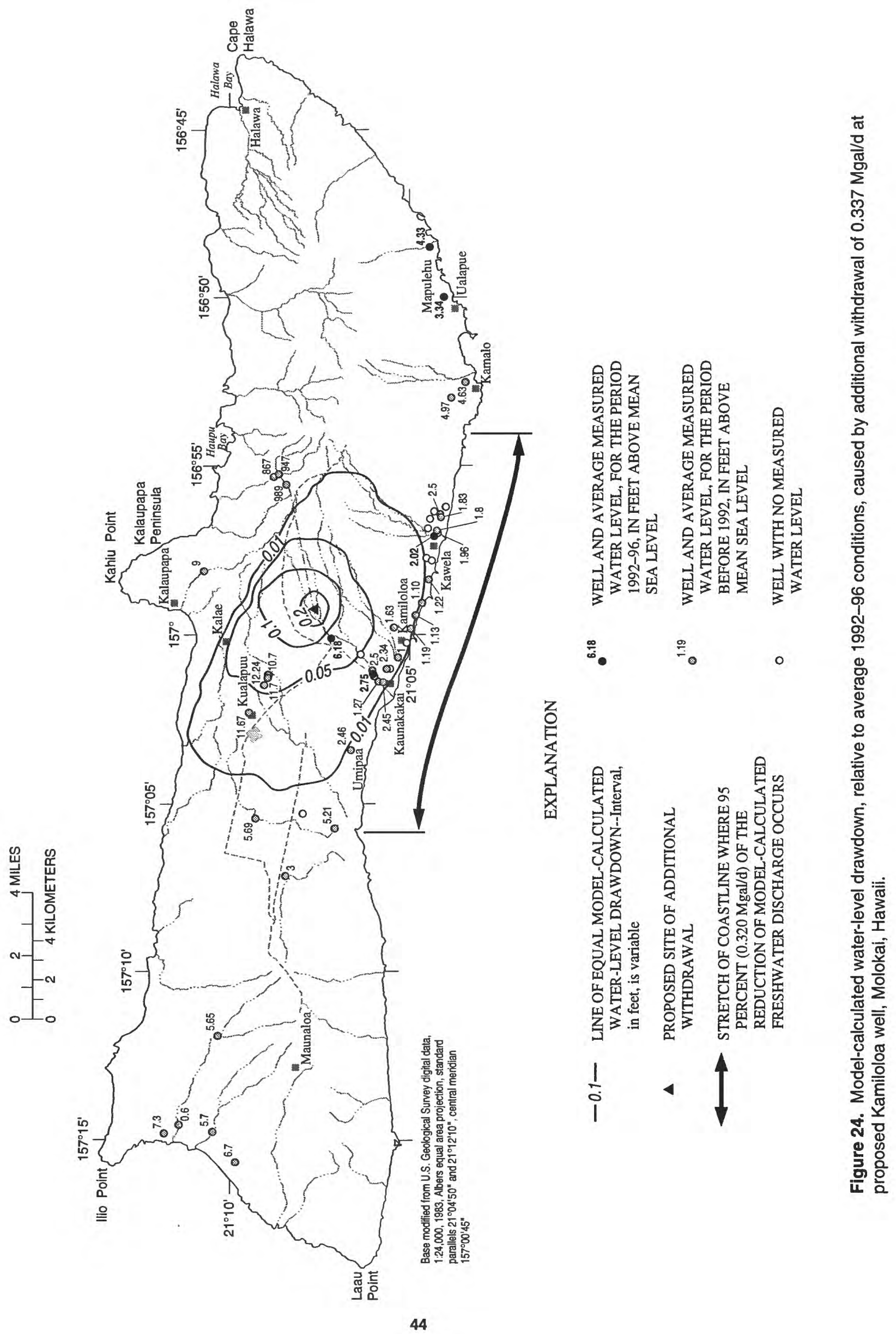




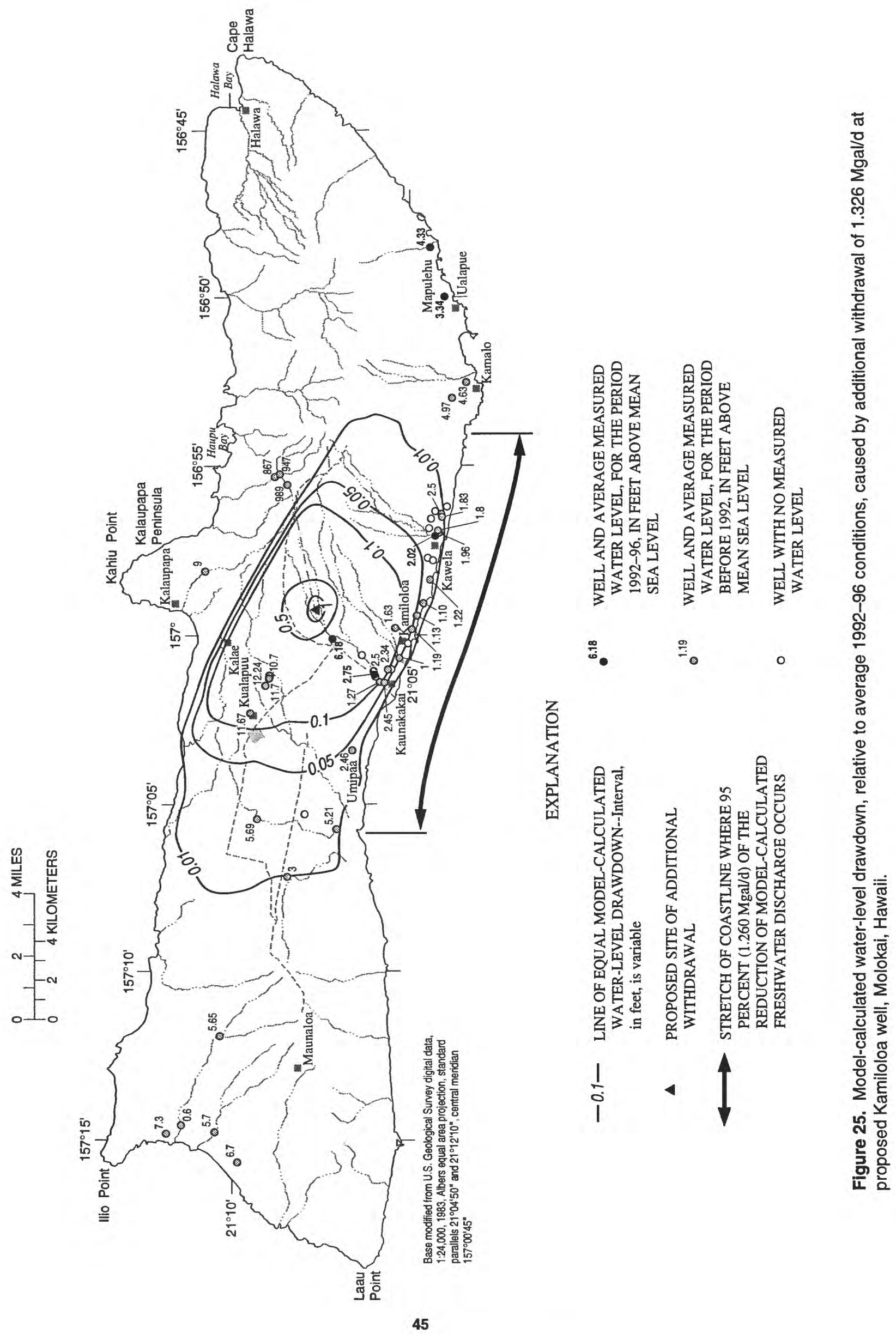


of the additional withdrawal. In the vicinity of wells in the Kualapuu area, model-calculated drawdown is between 0.1 and $0.5 \mathrm{ft}$. At both withdrawal rates, the model-calculated drawdown of $0.01 \mathrm{ft}$ or more extends into the East Molokai marginal dike zone near Kualapuu, but does not extend far into the East Molokai dike complex. The model-calculated drawdown is less than $0.01 \mathrm{ft}$ in the West Molokai dike-free volcanic rocks.

For steady-state conditions, the rate of groundwater discharge from the system will be reduced by an amount equal to the rate of additional withdrawal from the system. Model results indicate that, for both withdrawal rates at the proposed well, the stretch of coastline where discharge reduction is 95 percent of the additional withdrawal rate extends for a distance of about $13 \mathrm{mi}$ along the southern coast of the island (figs. 24 and 25). Along this 13-mi stretch of coastline, the rate of discharge, without the additional withdrawal, is $38.5 \mathrm{Mgal} / \mathrm{d}$. For additional withdrawal rates of 0.337 and $1.326 \mathrm{Mgal} / \mathrm{d}$, discharge along the delineated $13-\mathrm{mi}$ stretch of coastline is reduced by 0.8 and 3 percent, respectively. In both scenarios the reduction of modelcalculated discharge to northeastern Molokai streams is negligible.

\section{Scenario 3--Additional Withdrawal from the Kualapuu Area}

In scenario 3, the withdrawal rate from well 090101 was increased by $0.826 \mathrm{Mgal} / \mathrm{d}$, from $1.174 \mathrm{Mgal} / \mathrm{d}$ in the 1990 's base case to $2.000 \mathrm{Mgal} / \mathrm{d}$. Model-calculated drawdown of $0.01 \mathrm{ft}$ or more extends $6 \mathrm{mi}$ southeast and $8 \mathrm{mi}$ northwest from the well 0901-01 (fig. 26). In the Kualapuu area, model-calculated drawdown caused by withdrawing the additional $0.826 \mathrm{Mgal} / \mathrm{d}$ from well $0901-01$ is generally about 0.5 to $1.0 \mathrm{ft}$.

Along the northern coast of the island, the modelcalculated rate of discharge is reduced over a total stretch of coastline of $6 \mathrm{mi}$ (fig. 26). This reduction of model-calculated discharge is 14 percent of the additional withdrawal rate. Along this 6-mi stretch of coastline, the rate of discharge, in the absence of the additional withdrawal, is $4.3 \mathrm{Mgal} / \mathrm{d}$. For an additional withdrawal rate of $0.826 \mathrm{Mgal} / \mathrm{d}$, discharge along this stretch of coastline is reduced by 3 percent.

The stretch of southern coastline where discharge reduction is 81 percent of the additional withdrawal extends for a distance of about $10 \mathrm{mi}$ (fig. 26). This 10 - mi stretch of southern coastline, combined with the affected 6-mi stretch of northern coastline, account for 95 percent of the reduction in discharge. Within the $10-$ mi stretch of southern coastline, the rate of discharge, in the absence of the additional withdrawal is $19.4 \mathrm{Mgal} / \mathrm{d}$. For an additional withdrawal rate of $0.826 \mathrm{Mgal} / \mathrm{d}$ at well 0901-01, discharge within the delineated 10-mi stretch of southern coastline is reduced by 3 percent.

\section{MODEL LIMITATIONS}

The ground-water flow model of Molokai developed for this study has several limitations. Because available data are limited, the flow model is not considered to be calibrated. There are an insufficient number of monitor wells to define the spatial distribution of water levels in western Molokai, the inland parts of southeastern Molokai, and the dike complex of northeastern Molokai. Furthermore, no monitor wells exist to clearly define the water-level distribution in the vicinity of Kualapuu. Thus, the distribution of model-calculated water levels, although informative, is unverified in places.

Because of the lack of sufficient water-level data, the model developed for this study is not unique. That is, it is possible that different distributions of hydraulic conductivity and leakance can be used in a model to produce equally acceptable model-calculated water levels. A model zone was created to represent the marginal dike zone of East Molokai Volcano, and two coastal discharge zones were created for southern Molokai. Although this zonation is plausible, it is probable that other zonation geometries could produce similar results. The model developed for this study can be refined and a better representation of the flow system can be obtained as more data become available to constrain the model.

The recharge estimates used for this study were made on the basis of a detailed spatial analysis. However, it is recognized that the uncertainty associated with the recharge estimates may exceed 25 percent. Thus, the results of the ground-water flow model are limited by the uncertainty in the recharge estimates.

Because the ground-water flow model contains only a single layer, vertical hydraulic gradients cannot be simulated and model-calculated drawdown caused by additional withdrawals underestimates actual drawdown near partially penetrating wells. In addition, the 


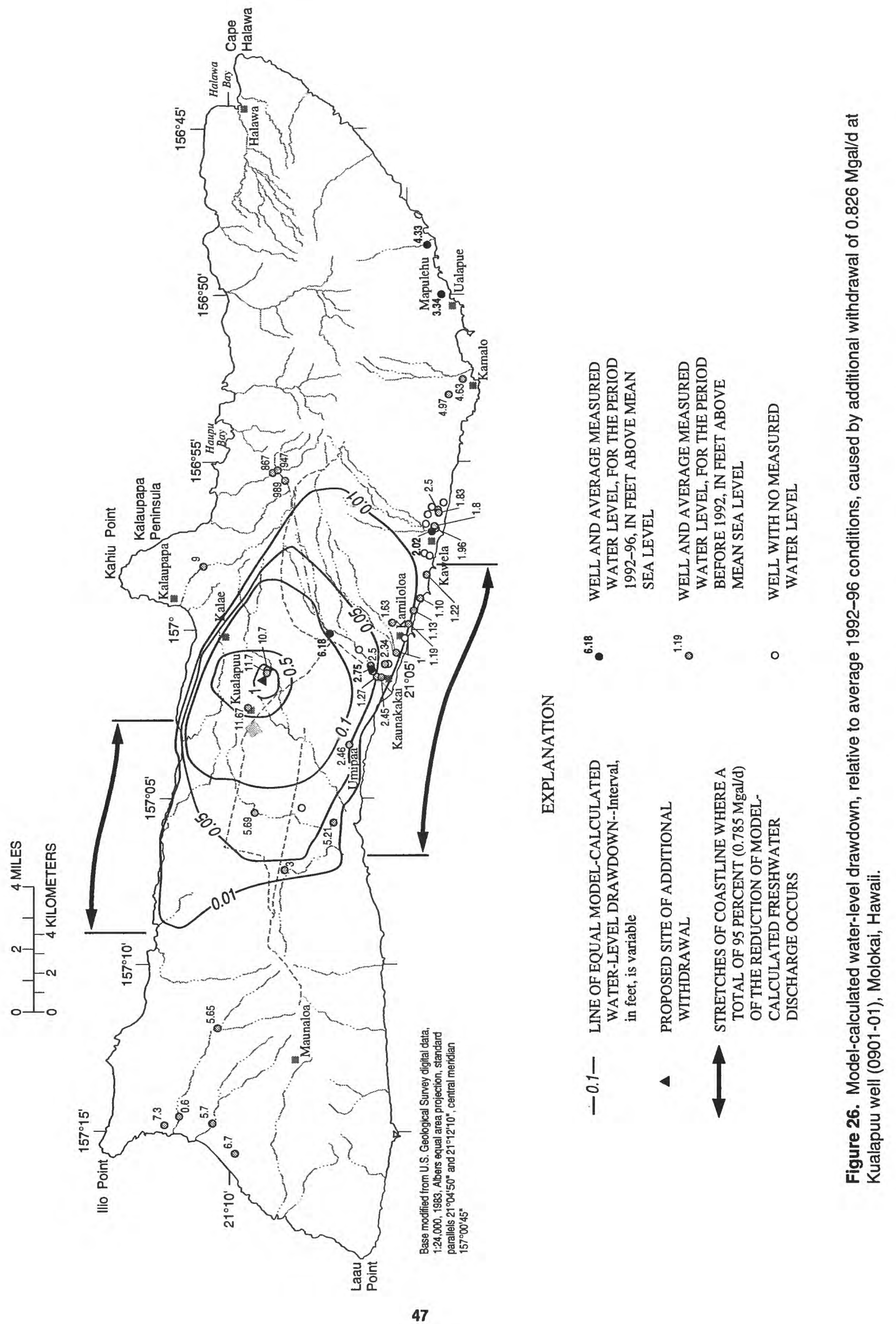


model should not be viewed as a quantitatively precise predictive tool because of the uncertainty in the model hydraulic-conductivity distribution. The model is, nevertheless, the best available tool for demonstrating the possible regional hydrologic effects of additional withdrawals on Molokai for steady-state conditions. The transient hydrologic effects of additional withdrawals are not modeled in this study.

The AQUIFEM-SALT code, which assumes a sharp interface between freshwater and saltwater, was used to simulate the regional flow system on Molokai. No deep monitor wells exist on Molokai which can provide information on the thickness of the transition zone between freshwater and underlying saltwater. This information is necessary to evaluate the validity of the sharp-interface assumption. In addition, the model developed for this study cannot be used to predict changes in salinity, either at the regional- or local-scale.

\section{DATA NEEDS}

Additional data are needed to improve the understanding of the ground-water flow system on Molokai. As more data become available, the ground-water flow model developed for this study can be refined and the accuracy of model predictions can thereby be improved. A few specific data needs are briefly described below.

1. A wider spatial distribution of water-levels is needed to define directions of ground-water flow and longer periods of measurement are needed to characterize the hydrologic effects of changes in recharge or withdrawals from the ground-water system. Additional water-level data also are needed to calibrate a ground-water flow model.

2. Aquifer-test data are needed to obtain independent estimates of hydraulic conductivity throughout the island. These independent estimates can serve as a check of the hydraulic conductivity estimates obtained using a numerical ground-water flow model.

3. Improved recharge estimates can lead to enhanced confidence in ground-water flow-model predictions.

4. Deep monitor wells are needed to define the vertical distribution of salinity in ground water. Data from these wells are essential to estimate the availability of fresh ground-water.
5. Streamflow data at additional sites are needed to estimate the total baseflow from streams. Improved baseflow estimates can be used as a check of model performance in northeastern Molokai.

6. More information is needed to better understand the subsurface geology, which is an important control on the distribution of water levels and the rates and directions of ground-water flow.

\section{SUMMARY AND CONCLUSIONS}

The island of Molokai, Hawaii, is composed mainly of two coalesced shield volcanoes: the older West Molokai Volcano, which rises to an altitude of $1,430 \mathrm{ft}$, and the younger East Molokai Volcano, which rises to an altitude of $4,961 \mathrm{ft}$. The Hoolehua Plain lies in the central saddle area of the island at altitudes less than about $800 \mathrm{ft}$. A high sea cliff runs along much of the northern coast. Kalaupapa Peninsula, formed by a rejuvenated-stage volcanic vent associated with the East Molokai Volcano, extends beyond the northern sea cliff. A coastal plain lies along the southern coast.

The West and East Molokai Volcanoes each have two primary rift zones marked by nearly vertical and nearly parallel dikes. The rift zones are hydrologically important because dikes have low permeability and tend to impound ground-water to high altitudes within interdike compartments. Numerous vent features associated with the East Molokai Volcano do not appear to lie along the trends of the two primary rift zones of the volcano, which may indicate that (1) a marginal dike zone exists or (2) more than two primary rift zones exist.

The zone of weathered West Molokai Volcanics and soil located beneath the contact of the West and East Molokai Volcanics likely impedes ground-water flow between East and West Molokai. However, no data are available to determine whether this unit is truly an effective barrier to ground-water flow.

Shade (in press) estimated that ground-water recharge was $188.6 \mathrm{Mgal} / \mathrm{d}$ for natural vegetation conditions. For the period from 1954-61, pineapple was cultivated in central and western Molokai, and average annual recharge in these areas was estimated to be 17.4 $\mathrm{Mgal} / \mathrm{d}$. Recharge for the entire island during this same period was estimated to be $201.3 \mathrm{Mgal} / \mathrm{d}$.

Most of the ground-water withdrawn is from the Kualapuu area, along the south shore of eastern Molo- 
kai, or from the dike complex in Waikolu Stream valley. The annual mean pumpage from wells reported during 1996 was $4.336 \mathrm{Mgal} / \mathrm{d}$. As of June 1997, the permitted ground-water withdrawals totaled $8.844 \mathrm{Mgal} / \mathrm{d}$.

Measured water levels are available primarily at wells along the southern coast and in the central plain area. In the vicinity of Kualapuu, water levels are generally about 10 to $12 \mathrm{ft}$ above sea level. Along the south shore, water levels are generally 1 to $3 \mathrm{ft}$ above sea level between Umipaa and Kawela, and 4 to $5 \mathrm{ft}$ above sea level between Kamalo and Mapulehu. The seasonal and interannual variations in water levels appear to be less than a foot at most wells. In general, hydrographs show no long-term trends in water levels.

Chloride concentration is generally used as an indicator of saltwater intrusion into the ground-water system. Although chloride concentrations at wells can change in response to changes in ground-water withdrawals and recharge, existing data do not indicate a significant long-term change in chloride concentration. In 1995, wells in the Kualapuu area produced water with a chloride concentration less than $200 \mathrm{mg} / \mathrm{L}$.

A two-dimensional, areal ground-water flow model using a modified version of the computer code AQUIFEM-SALT (Voss, 1984) was developed to simulate steady-state ground-water flow on Molokai. The finite-element mesh used in this study covers the entire island of Molokai.

For modeling purposes, the island was divided into seven horizontal-hydraulic-conductivity zones: (1) dike-free West Molokai Volcanics (flank-flow volcanic rocks), (2) dike-free East Molokai Volcanics (flankflow volcanic rocks), (3) Kalaupapa Volcanics, (4) West Molokai Volcanics confining unit, (5) West Molokai Volcanics dike complex, (6) East Molokai Volcanics dike complex exclusive of the marginal dike zone, and (7) East Molokai Volcanics marginal dike zone. The first three zones represent the dike-free, flank-flow volcanic rocks. The West Molokai confining-unit zone represents the zone formed by weathered volcanic rocks and soil, between West and East Molokai Volcanics. In this study, the West Molokai confining unit is represented in the two-dimensional model as a zone of reduced hydraulic conductivity. The West and East Molokai dike-complex zones are modeled as zones of lower overall hydraulic conductivity relative to the dike-free volcanic-aquifer zones. A model zone was created for the assumed East Molokai marginal dike zone, where numerous volcanic-vent features exist.

To estimate the hydraulic conductivities of the model zones, average recharge, withdrawals, and waterlevel conditions for the period 1954-61 were simulated. On the basis of available information, ground-water withdrawals on Molokai during the period 1954-61 averaged $0.731 \mathrm{Mgal} / \mathrm{d}$, and average annual recharge was estimated to be $201.3 \mathrm{Mgal} / \mathrm{d}$. On the basis of model results, the following horizontal hydraulic conductivities were estimated: (1) 1,000 feet per day for the dike-free volcanic rocks of East and West Molokai, (2) 100 feet per day for the marginal dike zone of the East Molokai Volcano, (3) 2 feet per day for the West Molokai dike complex, (4) 0.02 feet per day for the East Molokai dike complex, and (5) 500 feet per day for the Kalaupapa Volcanics. The spatial distribution of model-calculated water levels are in general agreement with the limited set of measured water levels. Modelcalculated ground-water discharge to streams is in general agreement with estimated baseflow.

The final hydraulic characteristics estimated from the model simulations for the 1954-61 period were used in the model to simulate water levels and discharges for a 1990's base-case scenario. Model-calculated water levels from the base case are lower than the model-calculated water levels from the 1954-61 simulation period because of decreased recharge and increased ground-water withdrawal rates.

Model results are in agreement with the general conceptual model of the flow system on Molokai, where ground water flows from the interior, high-recharge areas to the coast. The model-calculated ground-water divide separating flow to the northern and southern coasts lies to either the north or the south of the topographic divide but is generally not coincident with the topographic divide.

To estimate the hydrologic effects, relative to the 1990's base-case scenario, of withdrawing additional ground water, three scenarios were simulated. In scenarios 1 and 2, withdrawal rates of 0.377 and 1.326 $\mathrm{Mgal} / \mathrm{d}$, respectively, were simulated from a well located about $4 \mathrm{mi}$ southeast of Kualapuu and $3 \mathrm{mi}$ north of Kamiloloa. In scenario 3, the 1992-96 average withdrawal rate of $0.826 \mathrm{Mgal} / \mathrm{d}$ at well 0901-01 near Kualapuu was increased by $1.174 \mathrm{Mgal} / \mathrm{d}$ to 2.000 $\mathrm{Mgal} / \mathrm{d}$. 
In scenario 1 , model-calculated drawdown of 0.01 $\mathrm{ft}$ or more extends $4 \mathrm{mi}$ southeast and $6 \mathrm{mi}$ northwest from the proposed well. In the vicinity of wells in the Kualapuu area, model-calculated drawdown is less than $0.1 \mathrm{ft}$. Model results indicate that the stretch of coastline where discharge reduction is 95 percent of the additional withdrawal rate extends for a distance of about 13 $\mathrm{mi}$ along the southern coast of the island.

In scenario 2, model-calculated drawdown of 0.01 $\mathrm{ft}$ or more extends $6 \mathrm{mi}$ southeast and $9 \mathrm{mi}$ northwest from the well. In the vicinity of wells in the Kualapuu area, model-calculated drawdown is between 0.1 and $0.5 \mathrm{ft}$. As in scenario 1 , model results indicate that the stretch of coastline where discharge reduction is 95 percent of the additional withdrawal rate extends for a distance of about $13 \mathrm{mi}$ along the southern coast of the island.

In scenario 3, model-calculated drawdown of 0.01 $\mathrm{ft}$ or more extends $6 \mathrm{mi}$ southeast and $8 \mathrm{mi}$ northwest from the well 0901-01. In the Kualapuu area, modelcalculated drawdown caused by withdrawing the additional $0.826 \mathrm{Mgal} / \mathrm{d}$ from well $0901-01$ is generally about 0.5 to $1.0 \mathrm{ft}$. Model results indicate that the reduction in discharge along the northern coast of the island occurs over a total stretch of $6 \mathrm{mi}$. Model results also indicate that the stretch of southern coastline where discharge reduction accounts for 81 percent of the additional withdrawal extends for a distance of about $10 \mathrm{mi}$.

The ground-water flow model of Molokai developed for this study has several limitations. The most significant limitation is that, because of the lack of sufficient water-level data, the ground-water flow model is not considered to be calibrated and furthermore is not unique.

As more data become available, the ground-water flow model developed for this study can be refined and the accuracy of model-predictions can thereby be improved. Additional data needed to improve the understanding of the ground-water flow system on Molokai include: (1) a wider spatial distribution and longer periods of measurement of water-levels, (2) independent estimates of hydraulic conductivity, (3) improved recharge estimates, (4) information about the vertical distribution of salinity in ground water, (5) streamflow data at additional sites, and (6) improved information about the subsurface geology.

\section{REFERENCES CITED}

Anderson, R.N., Bradshaw, Blaine, and Marders, W.G., 1973, Molokai present and future: University of Hawaii, College of Tropical Agriculture, Hawaii Agricultural Experiment Station, Departmental Paper 17, 108 p.

Anthony, S.A., 1995, Evaluation of ground-water resources from available data, 1992, East Molokai Volcano, Hawaii: U.S. Geological Survey Water-Resources Investigations Report 95-4180, 32 p.

Austin, H.A.R., and Stearns, H.T., 1954, Methods for development and delivery of water for irrigation of Hawaiian Homes Commission Lands at Hoolehua, Island of Molokai: Report to the Hawaii Irrigation Authority, Territory of Hawaii, $57 \mathrm{p}$.

Baker, H.L., 1960, Molokai: Present and potential land use: University of Hawaii Land Study Bureau Bulletin no. 1, $90 \mathrm{p}$.

Blumenstock, D.I., and Price, Saul, 1967, Climate of Hawaii, in Climates of the States, no. 60-51, Climatography of the United States: U.S. Department of Commerce.

Camp Dresser and McKee, 1993, Groundwater modelling study: review of existing data, Ewa marina project: Report to Haseko (Ewa), Inc., Honolulu, Hawaii, September 1993, variously paged.

Clague, D.A., Dao-Gong, Chen, Murnane, Richard, Beeson, M.H., Lanphere, M.A., Dalrymple, G.B., Friesen, Walter, Holcomb, R.T., 1982, Age and petrology of the Kalaupapa Basalt, Molokai, Hawaii: Pacific Science, v. 36 , no. 4 , p. $411-420$.

Dorman, C.E., and Bourke, R.H., 1979, Precipitation over the Pacific Ocean, $30^{\circ} \mathrm{S}$ to $60^{\circ} \mathrm{N}$ : Monthly Weather Review, v. 107 , no. 7, p. 896-910.

Ekern, P.C., 1965, Evapotranspiration of pineapple in Hawaii: Plant Physiology, v. 40, no. 4, p. 736-739.

Ekern, P.C., and Chang, J-H., 1985, Pan evaporation: State of Hawai'i, 1894-1983: State of Hawaii, Department of Land and Natural Resources, Report R74, 172 p.

Elliot, W.P., and Reed, R.K., 1984, A climatological estimate of precipitation for the world ocean: Journal of Applied Meteorology, v. 23, no. 3, p. 434-439.

Furumoto, A.S., Campbell, J.F., and Hussong, D.M., 1970, Seismic studies of subsurface structure in the Ewa coastal plain, Oahu, Hawaii: Pacific Science, v. 24, no. 4, p. 529-542.

Giambelluca, T.W., 1983, Water balance of the Pearl HarborHonolulu basin, Hawai 'i, 1946-1975: University of Hawaii Water Resources Research Center Technical Report no. 151, 151 p.

Giambelluca, T.W., Loague, Keith, Green, R.E., and Nullet, M.A., 1996, Uncertainty in recharge estimation: impact on groundwater vulnerability assessments for the Pearl 
Harbor Basin, O'ahu, Hawai 'i, U.S.A.: Journal of Contaminant Hydrology, v. 23, p. 85-112.

Giambelluca, T.W., Nullet, M.A., and Schroeder, T.A., 1986, Rainfall atlas of Hawai ' $i$ : State of Hawaii, Department of Land and Natural Resources, Report R76, 267 p.

Hirashima, G.T., 1963, Aspects of ground-water storage and depletion along the Molokai Irrigation Tunnel, Molokai, Hawaii: State of Hawaii, Department of Land and Natural Resources, Circular C20, 21 p.

Howell, Hugh, 1938, Final report on water supply studies, Hawaii, F.P. No. 45, island of Molokai (abridged); Description of project objectives, estimate of costs: U.S. Bureau of Reclamation, $61 \mathrm{p}$.

Kauahikaua, Jim, 1993, Geophysical characteristics of the hydrothermal systems of Kilauea Volcano, Hawai'i: Geothermics, v. 22, no. 4, p. 271-299.

Langenheim, V.A.M., and Clague, D.A., 1987, The Hawaiian-Emperor volcanic chain, part II, stratigraphic framework of volcanic rocks of the Hawaiian islands, chap. 1 of Decker, R.W., Wright, T.L., and Stauffer, P.H., eds., Volcanism in Hawaii: U.S. Geological Survey Professional Paper 1350 , v. 1, p. 55-84.

Lindgren, Waldemar, 1903, The water resources of Molokai, Hawaiian islands: U.S. Geological Survey Water-Supply and Irrigation Paper No. 77, 62 p.

MacCarthy, G.R., 1941, Geophysical studies on the island of Molokai, Territory of Hawaii: Department of the Interior Press Release 160579, October 3, 1941, 2 p.

Macdonald, G.A., 1956, The structure of Hawaiian volcanoes: Verhandelingen Van Het Koninklijk Nederlandsh Geologisch Mijnbouwkundig Genootschap, vol. 16, p. 1-22.

Malahoff, Alexander, and Woollard, G.P., 1966, Magnetic surveys over the Hawaiian Islands and their geologic implications: Pacific Science, v. 20, no, 3, p. 265-311.

Mathewson, C.C., 1970, Submarine canyons and the shelf along the north coast of Molokai island, Hawaiian Ridge: Pacific Science, v. 24, no. 2, p. 235-244.

McDougall, Ian, 1964, Potassium-argon ages from lavas of the Hawaiian islands: Geological Society of America Bulletin, v. 75, no. 2, p. 107-128.

Meyer, William, and Souza, W.R., 1995, Factors that control the amount of water that can be diverted to wells in a high-level aquifer, in Hermann, Raymond, Back, William, Sidle, R.C., and Johnson, A.I., eds., Water Resources and Environmental Hazards: Emphasis on Hydrologic and Cultural Insight in the Pacific Rim, Proceedings of the American Water Resources Association Annual Summer Symposium, Honolulu, Hawaii, June 25-28, 1995, p. 207-216.

Miller, M.E., 1987, Hydrogeologic characteristics of central Oahu subsoil and saprolite: Implications for solute trans- port: Honolulu, Hawaii, University of Hawaii, M.S. thesis, $231 \mathrm{p}$.

Mink, J.F., and Lau, L.S., 1980, Hawaiian groundwater geology and hydrology, and early mathematical models: University of Hawaii Water Resources Research Center Technical Memorandum Report no. 62, 74 p.

Mink, J.F., and Lau, L.S., 1992, Aquifer identification and classification for Moloka'i: Groundwater protection strategy for Hawaii: University of Hawaii Water Resources Research Center Technical Report 187, 31 p.

Moore, J.G., Clague, D.A., Holcomb, R.T., Lipman, P.W., Normark, W.R., and Torresan, M.E., 1989, Prodigious submarine landslides on the Hawaiian ridge: Journal of Geophysical Research, v. 94, no. B12, p. 17,465-17,484.

Moore, J.G., and Krivoy, H.L., 1965, A reconnaissance gravity survey of the island of Molokai, Hawaii: Pacific Science, v. 19 , no. 3 , p. 343-345.

National Oceanic and Atmospheric Administration, 1989, Channels between Oahu, Molokai and Lanai, Nautical Chart 19351, 1:80,000 scale.

National Oceanic and Atmospheric Administration, 1993, Channels between Molokai, Maui, Lanai and Kahoolawe, Nautical Chart 19347, 1:80,000 scale.

Naughton, J.J., Macdonald, G.A., and Greenberg, V.A., 1980, Some additional potassium-argon ages of Hawaiian rocks: The Maui Volcanic Complex of Molokai, Maui, Lanai and Kahoolawe: Journal of Volcanology and Geothermal Research, v. 7, no. 3/4, p. 339-355.

Oki, D.S., 1997, Modeling the effects of pumping, barometric pressure, and ocean tides on ground-water levels in northern Oahu: Honolulu, Hawaii, University of Hawaii, Ph.D. dissertation, $321 \mathrm{p}$.

Oliver, A.M., 1995, Hawaii fact and reference book: Mutual Publishing, Honolulu, Hawaii, 274 p.

R.M. Towill Corporation, 1978, Feasibility study, surface water impoundment/recharge Pearl Harbor basin Oahu, Hawaii: variously paginated.

Seckel, G.R., 1962, Atlas of the oceanographic climate of the Hawaiian islands region: Fishery Bulletin 193, from Fishery Bulletin of the Fish and Wildlife Service, v. 61, p. 373-427, Fish and Wildlife Service, U.S. Department of the Interior.

Shade, P.J., in press, Water budget for the island of Molokai, Hawaii: U.S. Geological Survey Water-Resources Investigations Report 97-4155.

Souza, W.R., and Voss, C.I., 1987, Analysis of an anisotropic coastal aquifer system using variable-density flow and solute transport simulation: Journal of Hydrology, v. 92, p. 17-41.

State of Hawaii, 1966, Water resources development Molokai: Department of Land and Natural Resources, Division of Water and Land Development Bulletin 16, 69 p. 
State of Hawaii, 1975, The State of Hawaii data book, a statistical abstract: State of Hawaii, Department of Planning and Economic Development, November 1975.

State of Hawaii, 1990, Water Resources Protection Plan, volumes I and II, Hawaii Water Plan: State of Hawaii, Commission on Water Resource Management.

Stearns, H.T., and Macdonald, G.A., 1947, Geology and ground-water resources of the island of Molokai, Hawaii: Hawaii Division of Hydrography Bulletin 11, Territory of Hawaii, 113 p.

Strange, W.E., Woollard, G.P., and Rose, J.C., 1965, An analysis of the gravity field over the Hawaiian islands in terms of crustal structure: Pacific Science, v. 19, no. 3, p. 381-389.

Swain, L.A., 1973, Chemical quality of ground water in Hawaii: State of Hawaii, Department of Land and Natural Resources, Report R48, 54 p.

Swartz, J.H., 1939, Geophysical investigations in the Hawaiian islands: Transactions, American Geophysical Union, v. 20, p. 292-298.

Takasaki, K.J., 1986, Results of exploratory drilling for water in Waihanau Valley, Molokai, Hawaii: U.S. Geological Survey Water-Resources Investigations Report 85-4332, $26 \mathrm{p}$.

Takasaki, K.J., and Mink, J.F., 1985, Evaluation of major dike-impounded ground-water reservoirs, island of Oahu: U.S. Geological Survey Water-Supply Paper $2217,77 \mathrm{p}$.
U.S. Geological Survey, 1952, Topographic map of the island of Molokai, Hawaii, 1:62,500 scale.

Voss, C.I., 1984, AQUIFEM-SALT: A finite-element model for aquifers containing a seawater interface: U.S. Geological Survey Water-Resources Investigations Report 84-4263, $37 \mathrm{p}$.

Wahl, K.L., and Wahl, T.L., 1995, Determining the flow of Comal Springs at New Braunfels, Texas: Proceedings of Texas Water '95, A Component Conference of the First International Conference on Water Resources Engineering, American Society of Civil Engineers, August 1617, 1995, San Antonio, Texas, pp. 77-86.

Wentworth, C.K., 1938, Geology and ground water resources of the Palolo-Waialae District: Honolulu Board of Water Supply, Honolulu, Hawaii, 274 p.

Wentworth, C.K., and Macdonald, G.A., 1953, Structures and forms of basaltic rocks in Hawaii: U.S. Geological Survey Bulletin 994, 98 p.

Williams, J.A., and Soroos, R.L., 1973, Evaluation of methods of pumping test analyses for application to Hawaiian aquifers: University of Hawaii Water Resources Research Center Technical Report no. 70, 159 p. 


\section{APPENDIX A. MODIFICATION OF AQUIFEM-SALT CODE}

In the unmodified version of AQUIFEM-SALT (Voss, 1984), freshwater may enter the modeled aquifer in elements with an upper confining unit wherever $h_{0}$, the head overlying the confining unit, exceeds the model-calculated head in the aquifer. In offshore areas, $\mathrm{h}_{0}$ can be set to zero to avoid introducing freshwater sources from the ocean. The head overlying the ocean bottom, however, can be better-represented by using the freshwater head equivalent to the height of the saltwater column above the ocean bottom. With this representation, however, water overlying the ocean bottom can enter the aquifer where there is no freshwater lens or where the height of the equivalent freshwater column overlying the ocean bottom is greater than the head in the aquifer.

For this study, a modification was made to the AQUIFEM-SALT code, written in FORTRAN, to eliminate anomalous offshore sources of freshwater. The code was modified to set the confining-unit thickness to an arbitrary large value at elements where water enters the aquifer from the overlying confining unit. The effect of this modification is to decrease the confining-unit leakance to a value close to zero in those elements where water enters the aquifer from the overlying confining unit. If the head in the aquifer exceeds $h_{0}$ at any time step of the simulation, the confining-unit thickness reverts back to the originally assigned value. The code modifications are described below and will take effect if the parameter KOD1 is assigned a value of 1 in the AQUIFEM-SALT input file.

Change the following dimension statement in the subroutine AQUIFM from:

DIMENSION IN $(13, \mathrm{NE}), \operatorname{LRC}(\mathrm{NN}), \operatorname{INDEX}(\mathrm{NN}), \operatorname{IFLO}(\mathrm{NE}, 5)$,

$1 \quad \mathrm{LR}(\mathrm{NN}), \operatorname{NNEL}(\mathrm{NN})$, UFIX (NN)

to:

\footnotetext{
DIMENSION IN (13, NE), $\operatorname{LRC}(\mathrm{NN}), \operatorname{INDEX}(\mathrm{NN}), \operatorname{IFLO}(\mathrm{NE}, 5)$,

$1 \operatorname{LR}(\mathrm{NN}), \operatorname{NNEL}(\mathrm{NN}), \operatorname{UFIX}(\mathrm{NN}), \mathrm{THKO}(50000)$
}

Change the following line in subroutine AQUIFM from:

$$
244 \operatorname{READ}(1,860) \text { I, THK (I), HZERO (I) }
$$

to:

$$
\operatorname{READ}(1,860) I, \operatorname{THK}(I), \operatorname{HZERO}(I)
$$

244 THKO $(I)=$ THK $(I)$

Insert the following five lines of code

$$
\begin{aligned}
& \operatorname{IF}(\text { DLEAK (L) . GT . 0 . ) THEN } \\
& \text { THK (L) }=1.0 \mathrm{D}+50 \\
& \text { ELSE } \\
& \quad \text { THK (L) }=\text { THKO (L) } \\
& \text { ENDIF }
\end{aligned}
$$

between the following two existing lines in subroutine AQUIFM:

TLEAKT=TLEAKT+DLEAKT 
The modified AQUIFEM-SALT code is not suitable for transient simulations. In addition, the modified code is not suitable for simulating flow in an aquifer that receives freshwater inflow from an overlying aquifer through a confining unit.

A five-element strip model, consisting of two parallel rows of 6 nodes each, was made to test the modifications (fig. A1). The five square elements have a node spacing of $1,000 \mathrm{ft}$. Elements 1 and 2 are unconfined, and elements 3,4 , and 5 are confined and offshore. The altitude of the bottom of the aquifer was assumed to be $-6,000 \mathrm{ft}$ at all nodes. Nodes 1 to 4 were assigned aquifer-top altitudes of $100 \mathrm{ft}$, nodes 5 to 8 were assigned aquifer-top altitudes of $-150 \mathrm{ft}$, and nodes 9 to 12 were assigned aquifer-top altitudes of $-5,100 \mathrm{ft}$. The confining unit was assumed to have a uniform thickness of $100 \mathrm{ft}$ and a vertical hydraulic conductivity of $1 \mathrm{ft} / \mathrm{d}$. Elements 3,4 , and 5 were assigned $h_{0}$ values of 1.250 , 63.125 , and $125.000 \mathrm{ft}$, respectively. The horizontal hydraulic conductivity of the aquifer was assigned a value of $1,000 \mathrm{ft} / \mathrm{d}$. Recharge in element 1 was assigned a value of $1 \mathrm{ft}^{3} / \mathrm{s}$, and recharge in all other elements was assumed to be zero. Ground-water withdrawals were also set to zero.

The steady-state solution of this test problem was obtained using both the unmodified and modified versions of AQUIFEM-SALT. With the unmodified version of AQUIFEM-SALT, freshwater enters the aquifer from the confining unit at offshore elements 4 and 5 at rates of 1.08 and $3.97 \mathrm{ft}^{3} / \mathrm{s}$, respectively, and the discharge rate at element 3 is $6.05 \mathrm{ft}^{3} / \mathrm{s}$. With the modified version of AQUIFEM-SALT, freshwater is properly precluded from entering the aquifer from the confining unit at elements 4 and 5, and the discharge rate at element 3 is equal to $1 \mathrm{ft}^{3} / \mathrm{s}$.

\section{APPENDIX B. MODEL RESPONSE TO CHANGES IN HYDRAULIC CHARACTERISTICS}

A set of 64 simulations was used to determine whether acceptable agreement between model-calculated and measured water levels could be obtained using a parsimonious representation of the ground-water flow system on Molokai. In this set, model zones were combined in an attempt to produce a parsimonious representation of the system. Selected, representative results from the set are shown as scatter plots (figs. B1-B4) in which model-calculated water levels are plotted against measured water levels, and as model-response plots (figs. B5 and B6) in which families of model-calculated water levels at particular locations are plotted as a function of the vertical hydraulic conductivity of the coastal deposits of southern Molokai. The families of modelcalculated water levels are defined by different values of horizontal hydraulic conductivity of the grouped zone for the dike-free West and East Molokai Volcanics and East Molokai marginal dike zone.

\section{Description of Scatter Plots}

Selected, representative scatter plots of model-calculated versus measured water levels are presented in figures B1 through B4. Also shown for reference in each of the scatter plots is the line on which all data points would lie if the model-calculated water levels were exactly equal to the measured values. In each of figures B1 through B4, model results are shown for vertical hydraulic conductivities of $0.05,0.5,1.0$, and 5.0 $\mathrm{ft} / \mathrm{d}$ for the southern coastal-discharge zone, which is formed by the southeastern and southwestern coastaldischarge zones (fig. 15). Figures B1 and B2 show model results obtained using leakance values of 0.001 and 0.1 per day, respectively, for the northern coastaldischarge zone and a horizontal hydraulic conductivity of $500 \mathrm{ft} / \mathrm{d}$ for the grouped aquifer zone representing the dike-free East and West Molokai Volcanics and the East Molokai marginal dike zone. Figures B3 and B4 show model results obtained using leakance values of 0.001 and 0.1 per day, respectively, for the northern coastal-discharge zone and a horizontal hydraulic conductivity of $1,000 \mathrm{ft} / \mathrm{d}$ for the grouped aquifer zone. In the scatter plots, different symbols are used to represent the water levels at wells in different geographic areas.

Using a horizontal hydraulic conductivity of 500 $\mathrm{ft} / \mathrm{d}$ for the grouped aquifer zone, it is possible to simulate acceptable water levels of 10 to $12 \mathrm{ft}$ in the vicinity of Kualapuu (fig. B1), but model-calculated water levels at wells to the south of Kualapuu, near Kaunakakai, Kamiloloa, and Kawela, are generally too high. Using a horizontal hydraulic conductivity of $1,000 \mathrm{ft} / \mathrm{d}$ for the grouped aquifer zone, it is possible to obtain an acceptable match between measured and model-calculated water levels for wells near Kaunakakai, Kamiloloa, and Kawela, but model-calculated water levels at Kualapuu are too low (figs. B3 and B4). Model-calculated water levels at coastal wells near Kamalo and Ualapue are 


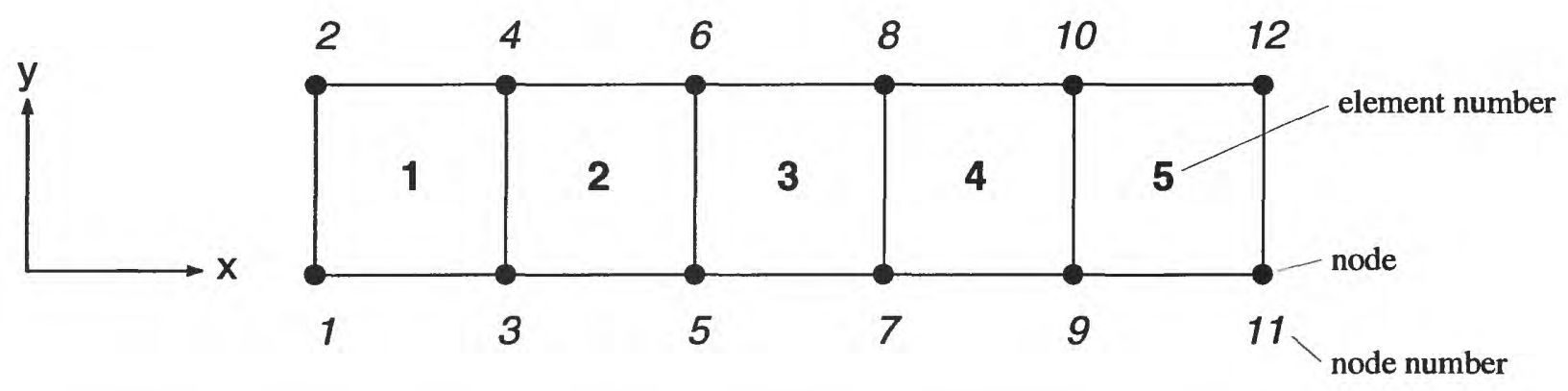

\begin{tabular}{rrrrrr}
\hline Node & $\begin{array}{c}x \\
\text { coordinate } \\
(\mathrm{ft})\end{array}$ & $\begin{array}{c}\mathrm{y} \\
\text { coordinate } \\
(\mathrm{ft})\end{array}$ & $\begin{array}{c}\text { Top } \\
\text { altitude } \\
(\mathrm{ft})\end{array}$ & $\begin{array}{c}\text { Bottom } \\
\text { altitude } \\
(\mathrm{ft})\end{array}$ & $\begin{array}{c}\text { Hydraulic } \\
\text { conductivity } \\
(\mathrm{ft} / \mathrm{d})\end{array}$ \\
\hline 1 & 0 & 0 & 100 & $-6,000$ & 1,000 \\
2 & 0 & 1,000 & 100 & $-6,000$ & 1,000 \\
3 & 1,000 & 0 & 100 & $-6,000$ & 1,000 \\
4 & 1,000 & 1,000 & 100 & $-6,000$ & 1,000 \\
5 & 2,000 & 0 & -150 & $-6,000$ & 1,000 \\
6 & 2,000 & 1,000 & -150 & $-6,000$ & 1,000 \\
7 & 3,000 & 0 & -150 & $-6,000$ & 1,000 \\
8 & 3,000 & 1,000 & -150 & $-6,000$ & 1,000 \\
9 & 4,000 & 0 & $-5,100$ & $-6,000$ & 1,000 \\
10 & 4,000 & 1,000 & $-5,100$ & $-6,000$ & 1,000 \\
11 & 5,000 & 0 & $-5,100$ & $-6,000$ & 1,000 \\
12 & 5,000 & 1,000 & $-5,100$ & $-6,000$ & 1,000 \\
\hline
\end{tabular}

\begin{tabular}{ccc}
\hline Element & $\begin{array}{c}\text { Leakance } \\
\text { (per day) }\end{array}$ & $\begin{array}{c}\text { Recharge } \\
\left(\mathrm{ft}^{3} / \mathrm{s}\right)\end{array}$ \\
\hline 1 & unconfined & 1 \\
2 & unconfined & 0 \\
3 & 0.01 & 0 \\
4 & 0.01 & 0 \\
5 & 0.01 & 0 \\
\hline
\end{tabular}

Figure A1. Finite-element strip model for test of AQUIFEM-SALT code modification. 

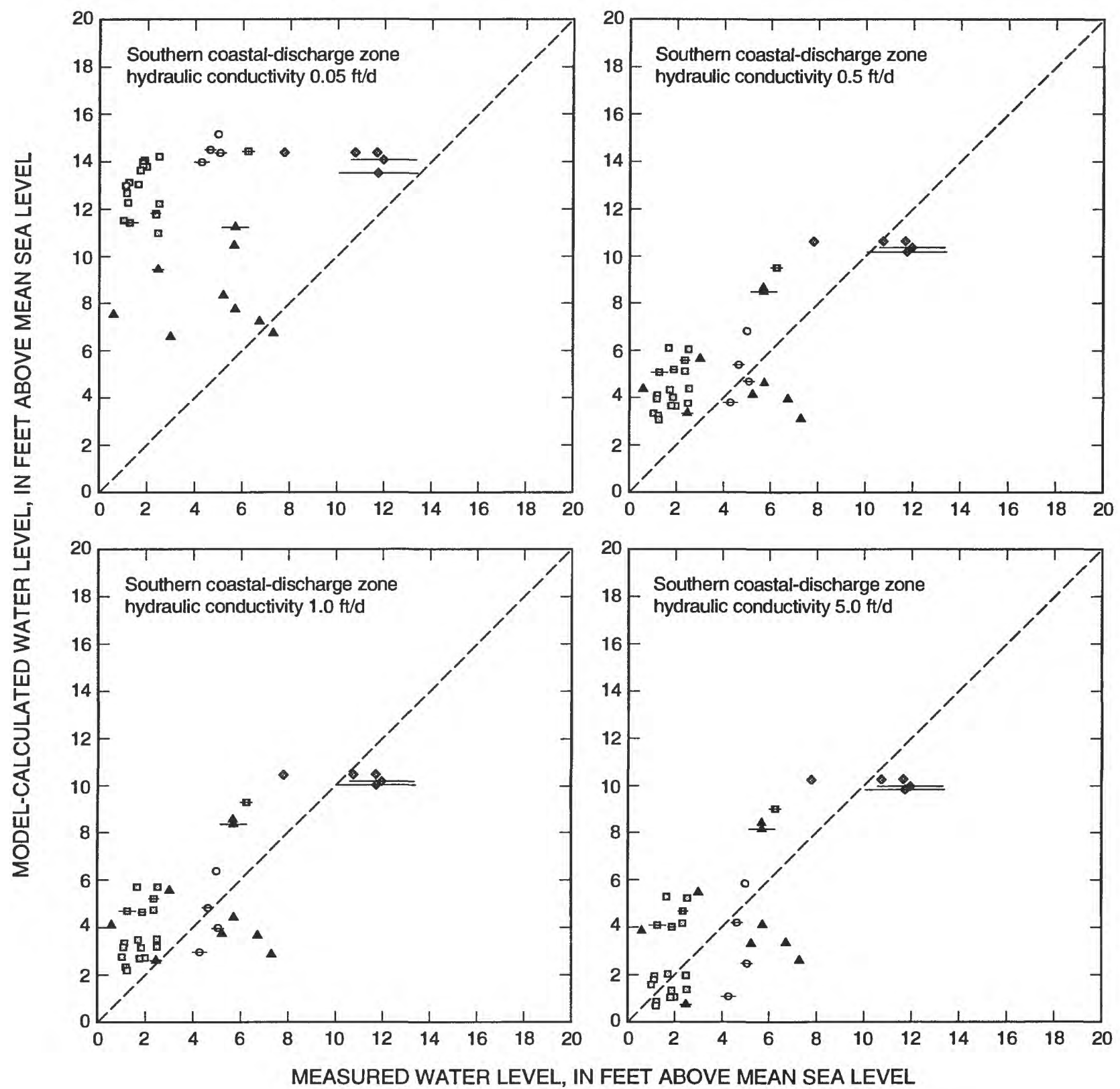

\section{EXPLANATION}

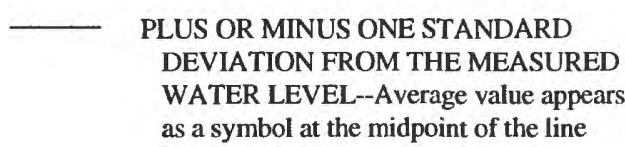
$---\quad$ LINE OF EQUAL MEASURED AND MODEL-CALCULATED WATER LEVELS

- WELLS NEAR KAMALO AND UALAPUE

- WELLS NEAR KAUNAKAKAI, KAMILOLOA, AND KAWELA

- WELLS NEAR KUALAPUU

- WELLS WEST OF KUALAPUU

Figure B1. Model-calculated and measured water levels for the period 1954-61, Molokai, Hawaii, for various values of the vertical hydraulic conductivity of the southern coastal-discharge zone, a leakance of 0.001 per day for the northern coastal-discharge zone, and an isotropic horizontal hydraulic conductivity of 500 feet per day for the model zones representing the dike-free West and East Molokai Volcanics and East Molokai marginal dike zone. 

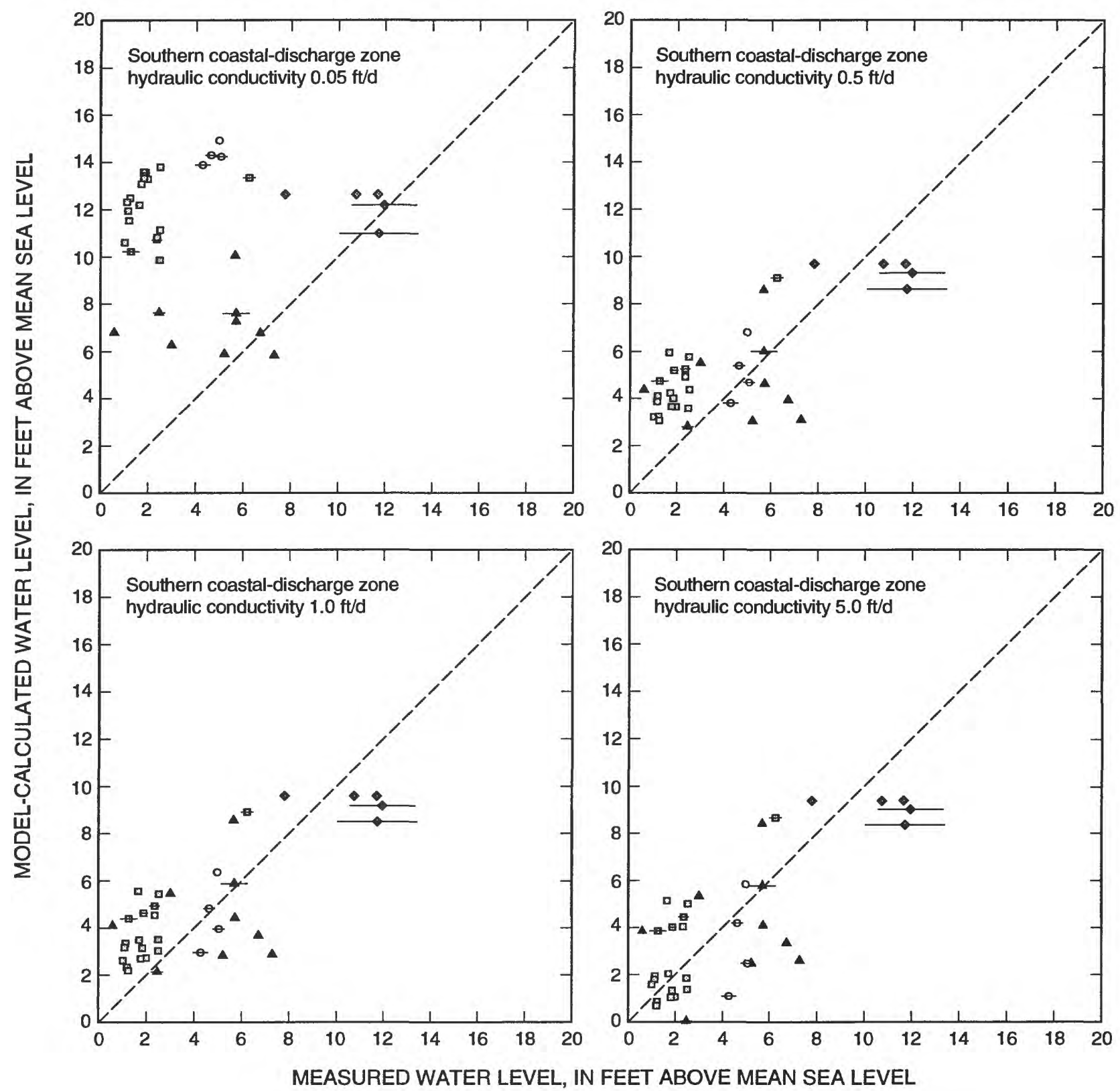

\section{EXPLANATION}

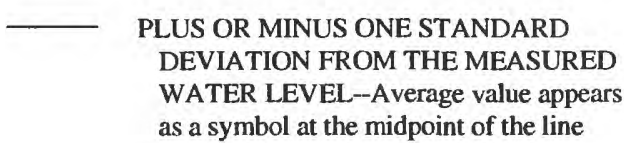

- - - LINE OF EQUAL MEASURED AND MODEL-CALCULATED WATER LEVELS
- WELLS NEAR KAMALO AND UALAPUE

- WELLS NEAR KAUNAKAKAI, KAMILOLOA, AND KAWELA

- WELLS NEAR KUALAPUU

- WELLS WEST OF KUALAPUU

Figure B2. Model-calculated and measured water levels for the period 1954-61, Molokai, Hawaii, for various values of the vertical hydraulic conductivity of the southern coastal-discharge zone, a leakance of 0.1 per day for the northern coastal-discharge zone, and an isotropic horizontal hydraulic conductivity of 500 feet per day for the model zones representing the dike-free West and East Molokai Volcanics and East Molokai marginal dike zone. 

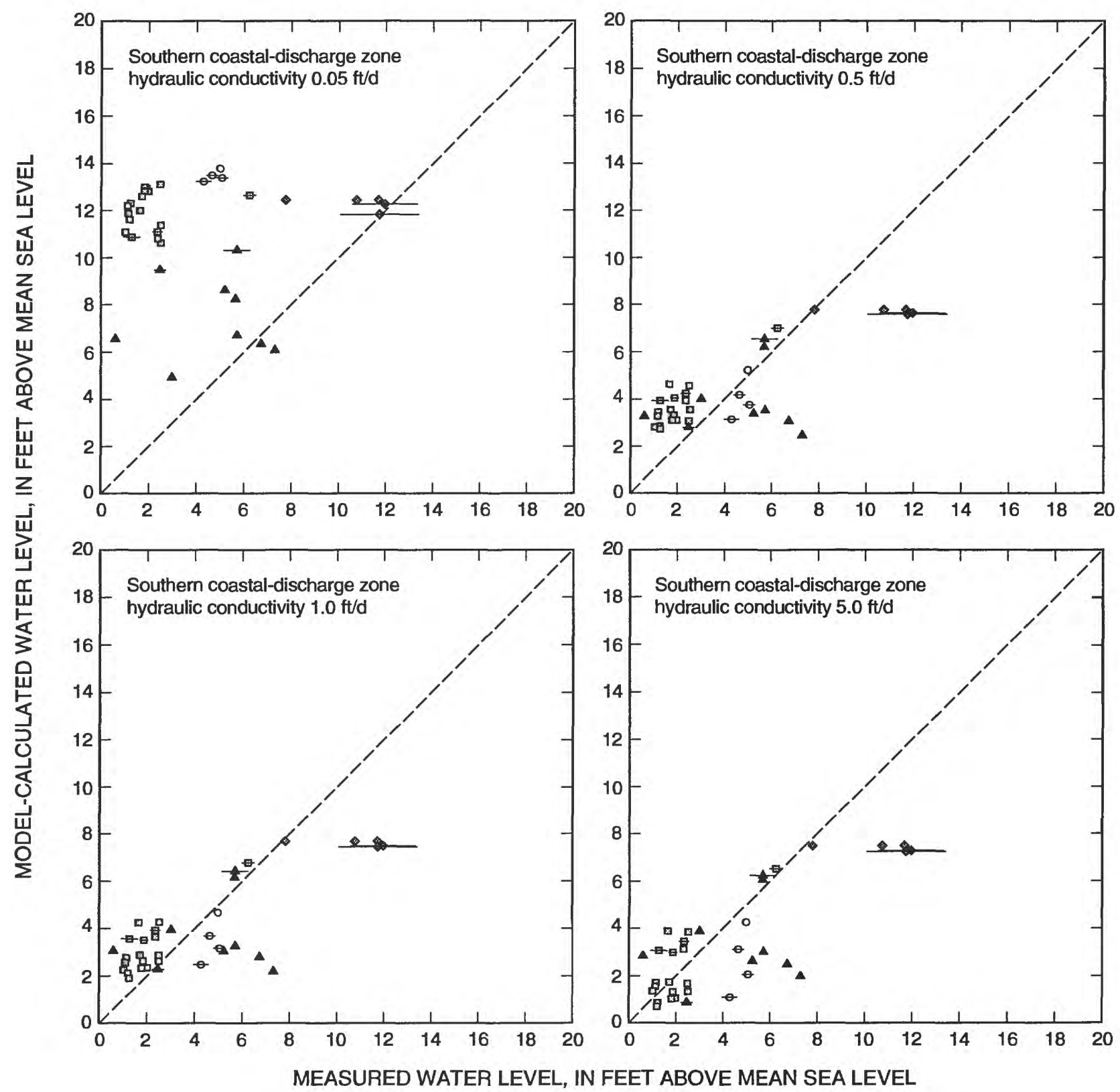

EXPLANATION

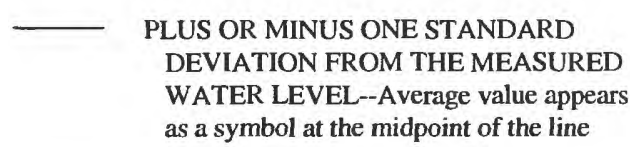

$---\quad$ LINE OF EQUAL MEASURED AND MODEL-CALCULATED WATER LEVELS

\section{- WELLS NEAR KAMALO AND UALAPUE \\ - WELLS NEAR KAUNAKAKAI, KAMILOLOA, AND KAWELA}

- WElls NEAR KUALAPUU

- WELLS WEST OF KUALAPUU

Figure B3. Model-calculated and measured water levels for the period 1954-61, Molokai, Hawaii, for various values of the vertical hydraulic conductivity of the southern coastal-discharge zone, a leakance of 0.001 per day for the northern coastal-discharge zone, and an isotropic horizontal hydraulic conductivity of 1,000 feet per day for the model zones representing the dike-free West and East Molokai Volcanics and East Molokai marginal dike zone. 

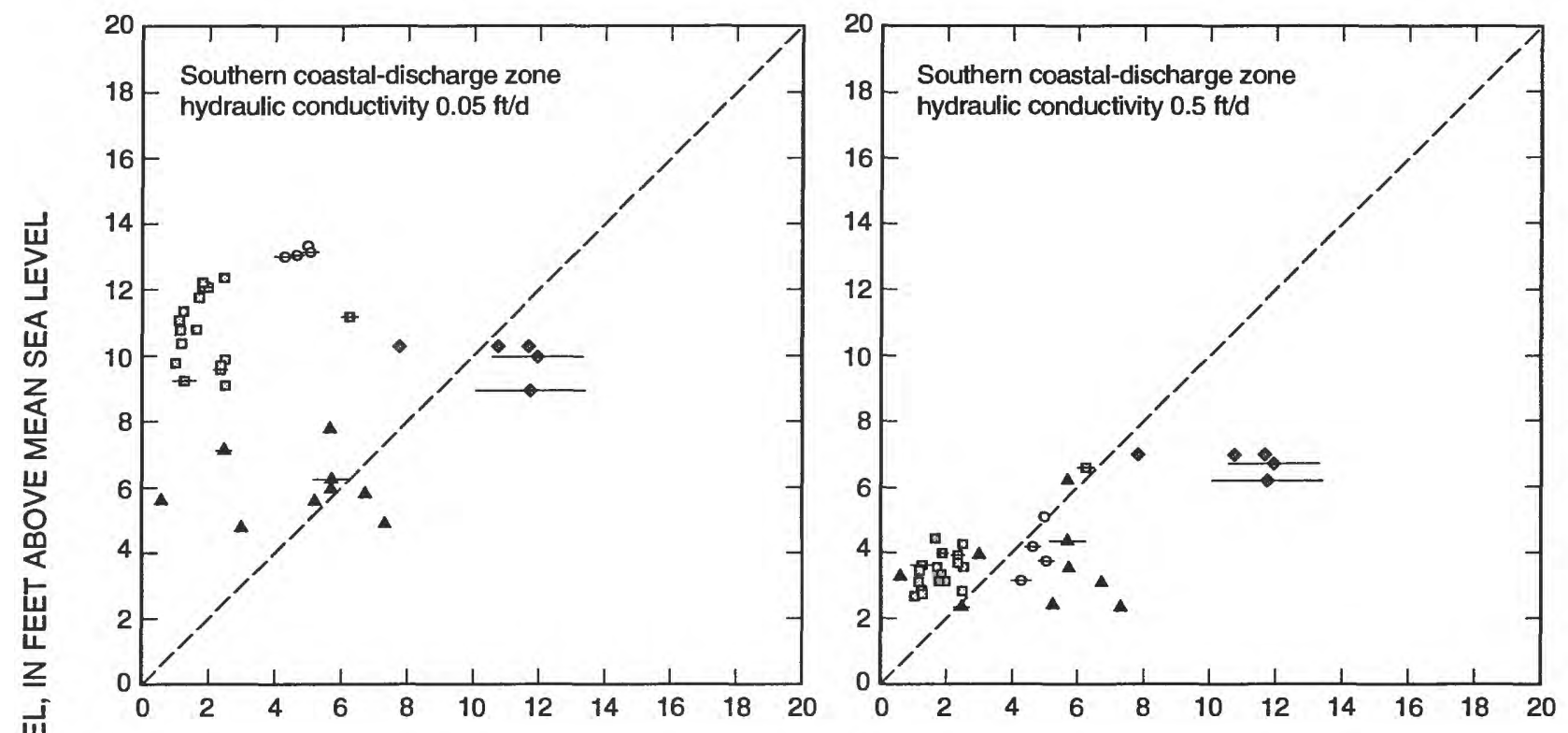

岂
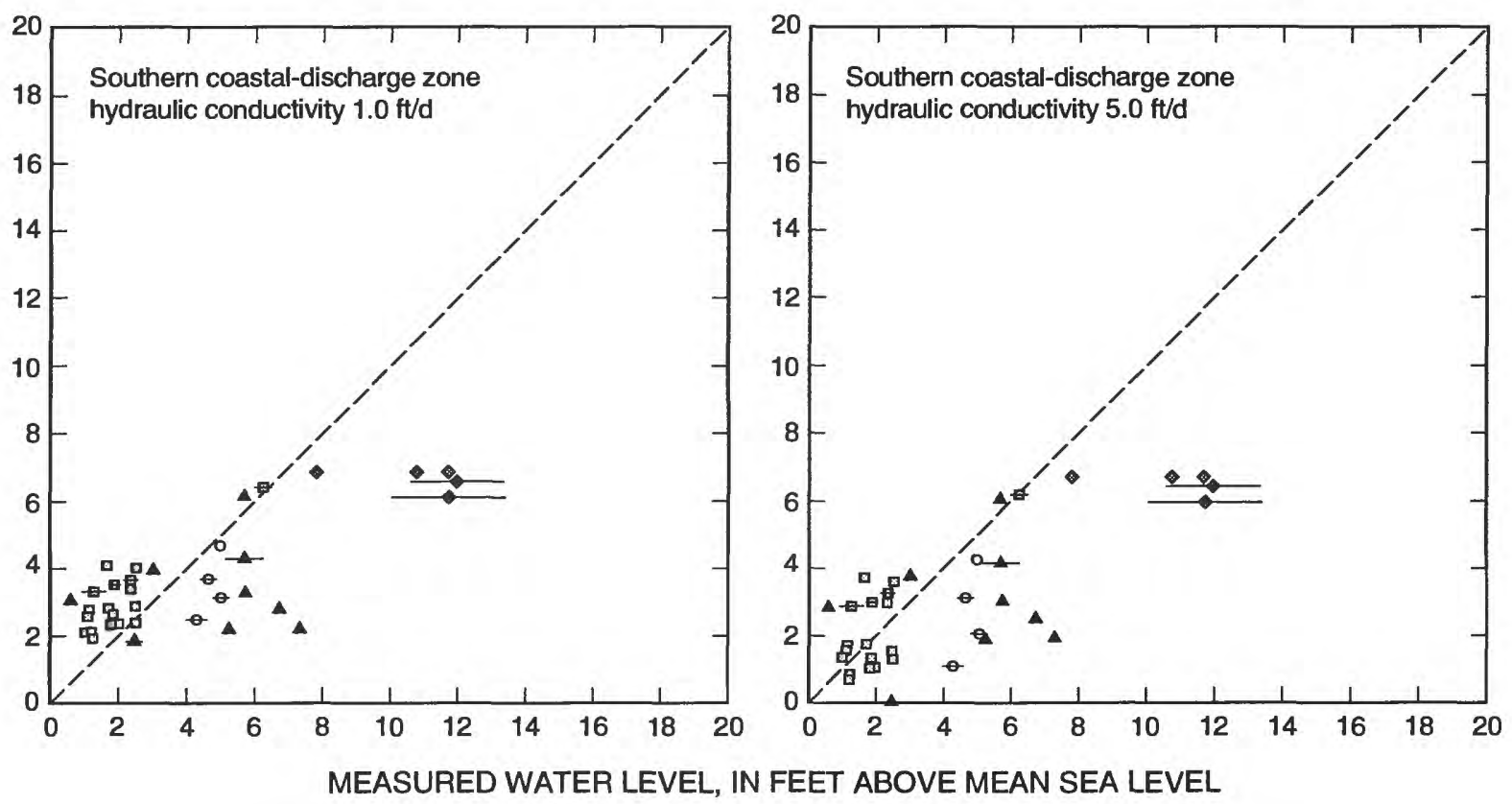

EXPLANATION

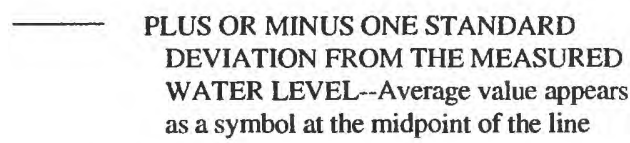

- - - LINE OF EQUAL MEASURED AND MODEL-CALCULATED WATER LEVELS

\section{- WELLS NEAR KAMALO AND UALAPUE \\ - WELLS NEAR KAUNAKAKAI, KAMILOLOA, AND KAWELA}

- WELLS NEAR KUALAPUU

A WELLS WEST OF KUALAPUU

Figure B4. Model-calculated and measured water levels for the period 1954-61, Molokai, Hawaii, for various values of the vertical hydraulic conductivity of the southern coastal-discharge zone, a leakance of 0.1 per day for the northern coastal-discharge zone, and an isotropic horizontal hydraulic conductivity of 1,000 feet per day for the model zones representing the dike-free West and East Molokai Volcanics and East Molokai marginal dike zone. 

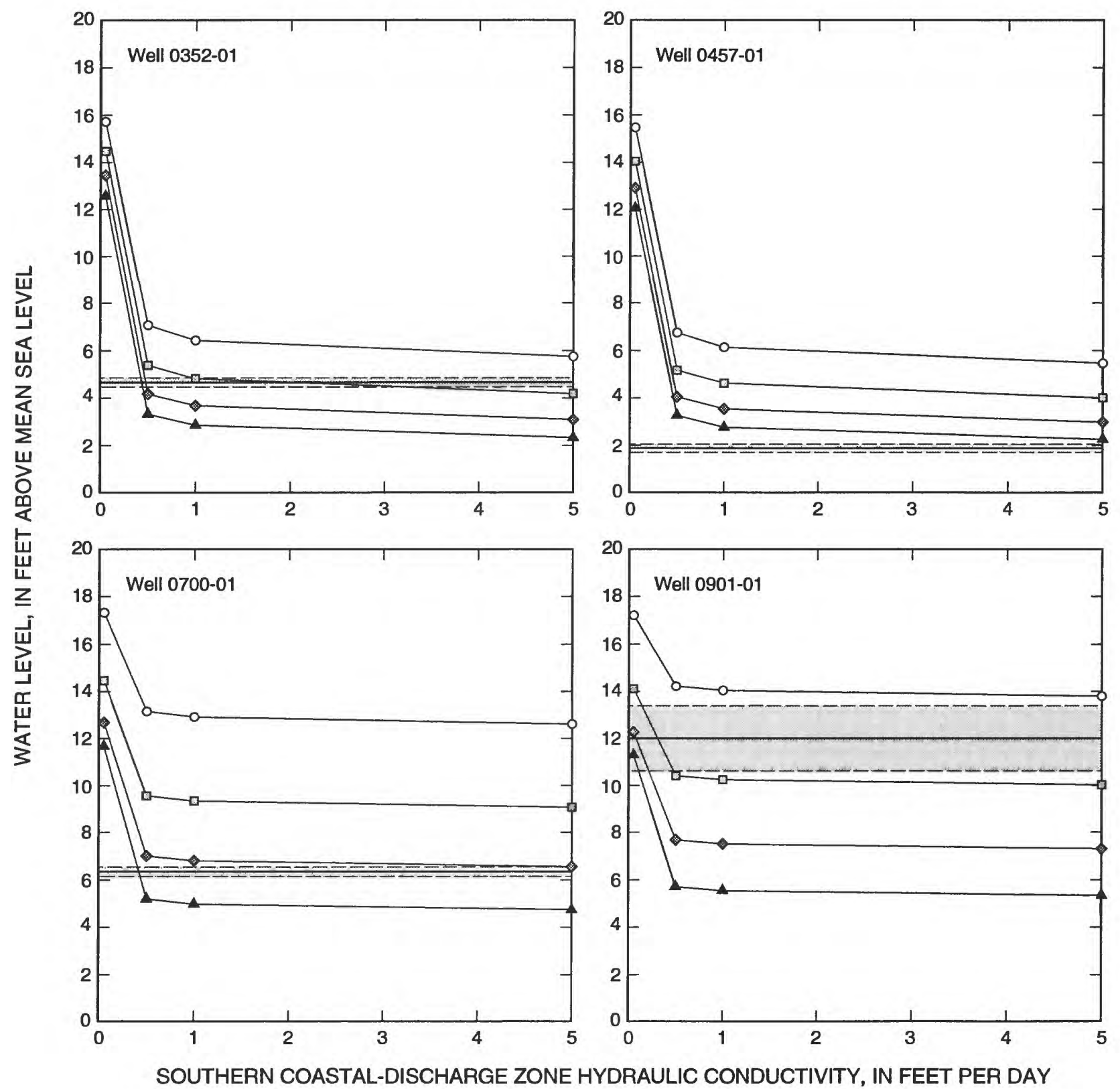

EXPLANATION

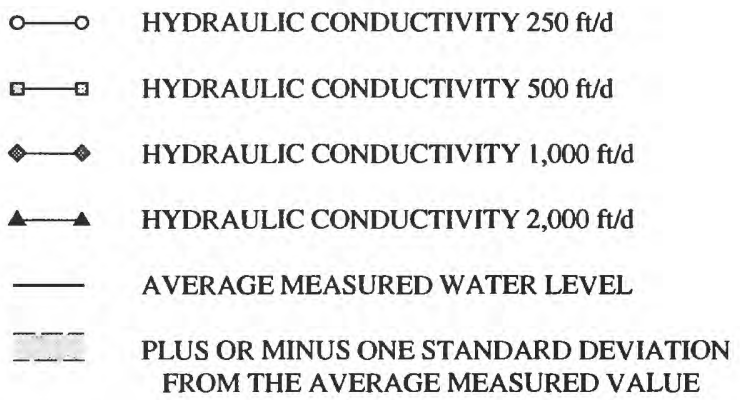

Figure B5. Response of the ground-water flow model to the vertical hydraulic conductivity of the southern coastal-discharge zone for a leakance of 0.001 per day for the northern coastal-discharge zone, and isotropic horizontal hydraulic conductivities of 250; $500 ; 1,000$; and 2,000 feet per day for the model zones representing the dike-free West and East Molokai Volcanics and East Molokai marginal dike zone. 

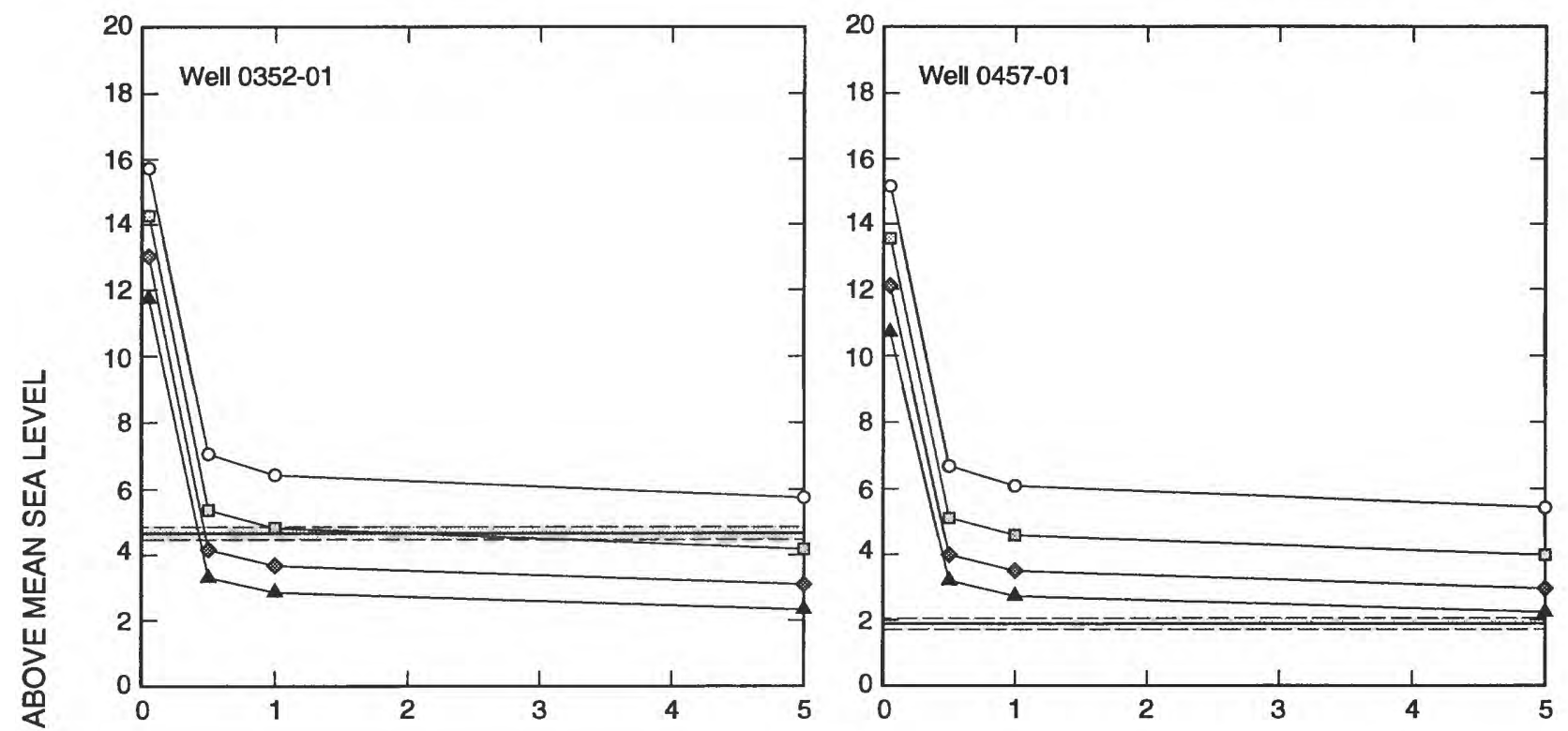

岂
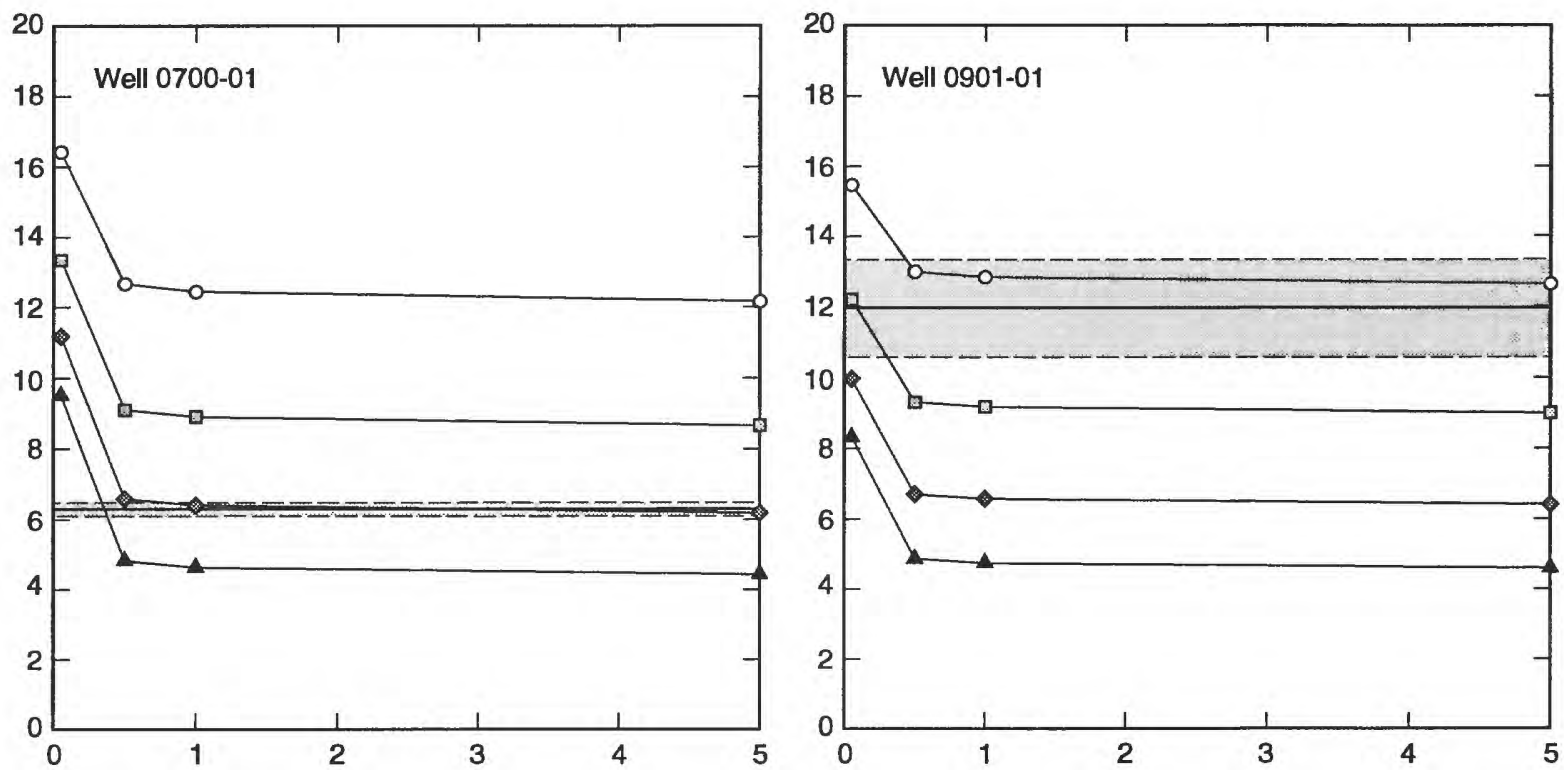

SOUTHERN COASTAL-DISCHARGE ZONE HYDRAULIC CONDUCTIVITY, IN FEET PER DAY

EXPLANATION

$\multimap$ HYDRAULIC CONDUCTIVITY $250 \mathrm{ft} / \mathrm{d}$

$\square$ HYDRAULIC CONDUCTIVITY $500 \mathrm{ft} / \mathrm{d}$

$\longrightarrow$ HYDRAULIC CONDUCTIVITY $1,000 \mathrm{ft} / \mathrm{d}$

$\triangle \quad$ HYDRAULIC CONDUCTIVITY $2,000 \mathrm{ft} / \mathrm{d}$

AVERAGE MEASURED WATER LEVEL

PLUS OR MINUS ONE STANDARD DEVIATION FROM THE AVERAGE MEASURED VALUE

Figure B6. Response of the ground-water flow model to the vertical hydraulic conductivity of the southern coastal-discharge zone for a leakance of 0.1 per day for the northern coastal-discharge zone, and isotropic horizontal hydraulic conductivities of 250;500; 1,000; and 2,000 feet per day for the model zones representing the dike-free West and East Molokai Volcanics and East Molokai marginal dike zone. 
within about a foot of the corresponding measured water levels using a hydraulic conductivity of $0.5 \mathrm{ft} / \mathrm{d}$ for the southern coastal-discharge zone (figs. B1-B4). However, using a hydraulic conductivity of $0.5 \mathrm{ft} / \mathrm{d}$ for the southern coastal discharge zone results in modelcalculated water levels at wells near Kaunakakai, Kamiloloa, and Kawela that are too high.

\section{Description of Model-Response Plots}

Selected, representative model-response results for wells near Kualapuu (0901-01), Kamiloloa (0700-01), Kawela (0457-01), and Kamalo (0352-01) are shown in figures B5 and B6. (Note that well 0700-01 is actually north of Kamiloloa.) In figures B5 and B6, model results are shown for horizontal hydraulic conductivities of 250; 500; 1,000; and 2,000 ft/d for the grouped aquifer zone, and vertical hydraulic conductivities of $0.05,0.5,1.0$, and $5.0 \mathrm{ft} / \mathrm{d}$ for the southern coastal-discharge zone. Figure B5 shows results for a northerncoastal-discharge-zone leakance of 0.001 per day and figure B6 shows results for a leakance of 0.1 per day. In figures B5 and B6, a solid horizontal line is used to represent the average measured water level at the well for 1954-61, if data for that period were available, or for the entire period of record, if no data were available for 1954-61. Dashed horizontal lines above and below the solid horizontal line represent plus and minus one standard deviation, respectively, from the average measured water level.

The average measured water level at well 0352-01 is $4.63 \mathrm{ft}$ above mean sea level. For well 0352-01, the intersection of each curve with the horizontal line at $4.63 \mathrm{ft}$ yields the best value of vertical hydraulic conductivity of the southern coastal-discharge zone (read off the horizontal axis) for the given horizontal hydraulic conductivity of the grouped aquifer zone and northern-coastal-discharge-zone leakance represented by the curve. The curve for a hydraulic conductivity of $250 \mathrm{ft} / \mathrm{d}$ for the grouped aquifer zone does not intersect the horizontal line at $4.63 \mathrm{ft}$ within the tested ranges of leakance values of the northern coastal-discharge zone and vertical hydraulic conductivity values of the southern coastal-discharge zone (see for example figures B5 and B6). This indicates that the northern-coastal-dischargezone leakance or southern-coastal-discharge-zone vertical hydraulic conductivity values tested are too low, or, more likely, that the hydraulic conductivity of $250 \mathrm{ft} / \mathrm{d}$ for the aquifer is too low. Comparison of figures B5 and
B6 indicates that model-calculated water levels at well 0352-01 are relatively unaffected by changes in the value for the northern coastal-discharge-zone leakance. Using horizontal hydraulic conductivities ranging from 1,000 to $2,000 \mathrm{ft} / \mathrm{d}$ for the grouped aquifer zone, modelresponse results for well 0352-01 indicate that the best vertical hydraulic conductivity for the southern coastaldischarge zone is between about 0.4 and $0.6 \mathrm{ft} / \mathrm{d}$.

The average measured water level at well 0700-01 is $6.24 \mathrm{ft}$ above mean sea level. For well 0700-01, best model results are obtained using hydraulic conductivities of $2,000 \mathrm{ft} / \mathrm{d}$ for the grouped aquifer zone and 0.4 $\mathrm{ft} / \mathrm{d}$ for the southern coastal-discharge zone. Using these same hydraulic conductivities, however, results in a model-calculated water level at well 0901-01 that is lower than the measured water level at that well. Within the range of hydraulic-conductivity values represented in figures B5 and B6, model-calculated water levels at well 0457-01 are higher than the average measured water level at the well.

\section{Discussion of Parsimonious Model}

Results from the 64 simulations indicate that a parsimonious model, in which the East Molokai marginal dike zone is grouped with the West and East Molokai Volcanics and a single discharge zone is used for the southern coast, is not capable of producing model-calculated water levels in agreement with measured water levels in all areas. However, information from these simulations narrowed the ranges of hydraulic characteristics for the various zones and was used to estimate the final hydraulic-conductivity and leakance values (table 4). 